\title{
Bees and wasps in agricultural landscapes: effects of dispersal corridors and land-use intensity at multiple spatial scales
}

\author{
Dissertation \\ zur Erlangung des Doktorgrades \\ der Mathematisch-Naturwissenschaftlichen Fakultäten \\ der Georg-August-Universität zu Göttingen
}

vorgelegt von

Andrea Alexandra Violetta Holzschuh

aus Alzenau i.Ufr.

Göttingen 2006 
D 7

Referent: Prof. Dr. Teja Tscharntke

Korreferent: Prof. Dr. Matthias Schaefer

Tag der mündlichen Prüfung: 3.5.2006 


\section{Contents}

\section{General introduction}

Introduction 3

Study areas $\quad 5$

$\begin{array}{lr}\text { Study organisms } & 8\end{array}$

$\begin{array}{ll}\text { Main questions } & 10\end{array}$

$\begin{array}{ll}\text { Results and conclusions } & 11\end{array}$

$\begin{array}{lr}\text { References } & 12\end{array}$

2. Diversity of flower-visiting bees in cereal fields:

effects of farming system, landscape composition and regional context

$\begin{array}{lr}\text { Abstract } & 15\end{array}$

$\begin{array}{lr}\text { Introduction } & 17\end{array}$

$\begin{array}{ll}\text { Methods } & 19\end{array}$

$\begin{array}{ll}\text { Results } & 23\end{array}$

$\begin{array}{ll}\text { Discussion } & 27\end{array}$

$\begin{array}{ll}\text { References } & 31\end{array}$

3. Landscape-scale effects of crop-noncrop resource fluxes: organic farming enhances bee diversity in fallow strips

$\begin{array}{ll}\text { Abstract } & 35\end{array}$

$\begin{array}{ll}\text { Introduction } & 37\end{array}$

$\begin{array}{ll}\text { Methods } & 38\end{array}$

$\begin{array}{ll}\text { Results } & 41\end{array}$

$\begin{array}{ll}\text { Discussion } & 44\end{array}$

$\begin{array}{lr}\text { References } & 48\end{array}$ 
4. Landscape context, organic farming and fallow strips influence nest colonization of bees and wasps

$\begin{array}{lr}\text { Abstract } & 52\end{array}$

$\begin{array}{ll}\text { Introduction } & 54\end{array}$

$\begin{array}{ll}\text { Methods } & 56\end{array}$

$\begin{array}{lr}\text { Results } & 60\end{array}$

$\begin{array}{ll}\text { Discussion } & 63\end{array}$

$\begin{array}{ll}\text { References } & 67\end{array}$

5. Grassy corridors in cropland landscapes enhance nest site colonization of solitary wasps

$\begin{array}{ll}\text { Abstract } & 71\end{array}$

$\begin{array}{ll}\text { Introduction } & 73\end{array}$

$\begin{array}{ll}\text { Methods } & 75\end{array}$

$\begin{array}{ll}\text { Results } & 79\end{array}$

$\begin{array}{ll}\text { Discussion } & 84\end{array}$

$\begin{array}{lr}\text { References } & 88\end{array}$

$\begin{array}{lr}\text { Summary } & 92\end{array}$

$\begin{array}{ll}\text { Danksagung } & 95\end{array}$

$\begin{array}{ll}\text { Publikationen } & 97\end{array}$

Curriculum vitae 


\section{Chapter 1}

\section{General introduction}

\section{Introduction}

Traditionally, agricultural landscapes developed over centuries as a patchwork of nonintensively farmed crop and noncrop land. During the last decades, agrochemical applications have greatly increased and a higher proportion of the available land has been intensively exploited (Tilman et al. 2001, Benton et al. 2003). Crop fields mainly used for cereal production have expanded at the cost of noncrop areas, and hedges and fallow strips have been lost in the course of field enlargement (Stoate et al. 2001). On a global scale, agricultural intensification is considered as one of the most serious threats to biodiversity in agroecosystems (Krebs et al. 1999).

Local low-intensity management such as organic farming target to counteract the current decline of biodiversity in agroecosystems (Krebs et al. 1999) and there is evidence that some organism groups may benefit from organic compared to conventional farming (reviewed in Bengtsson et al. 2005, Hole 2005) (Fig. 1). However, most species only spend parts of their lifecycle in arable fields and require noncrop habitats for reproduction, hibernation or as refuges after disturbance (Stoate et al. 2001). Thus, organisms may perceive their environment at larger than field scales (Kareiva 1990, Jonsen \& Fahrig 1997, Tscharntke et al. 2005), and effects of local farming intensity may be negligible compared to effects acting at a landscape scale (Weibull et al. 2003, Kremen et al. 2004, Clough et al. 2005) (Fig. 2). 


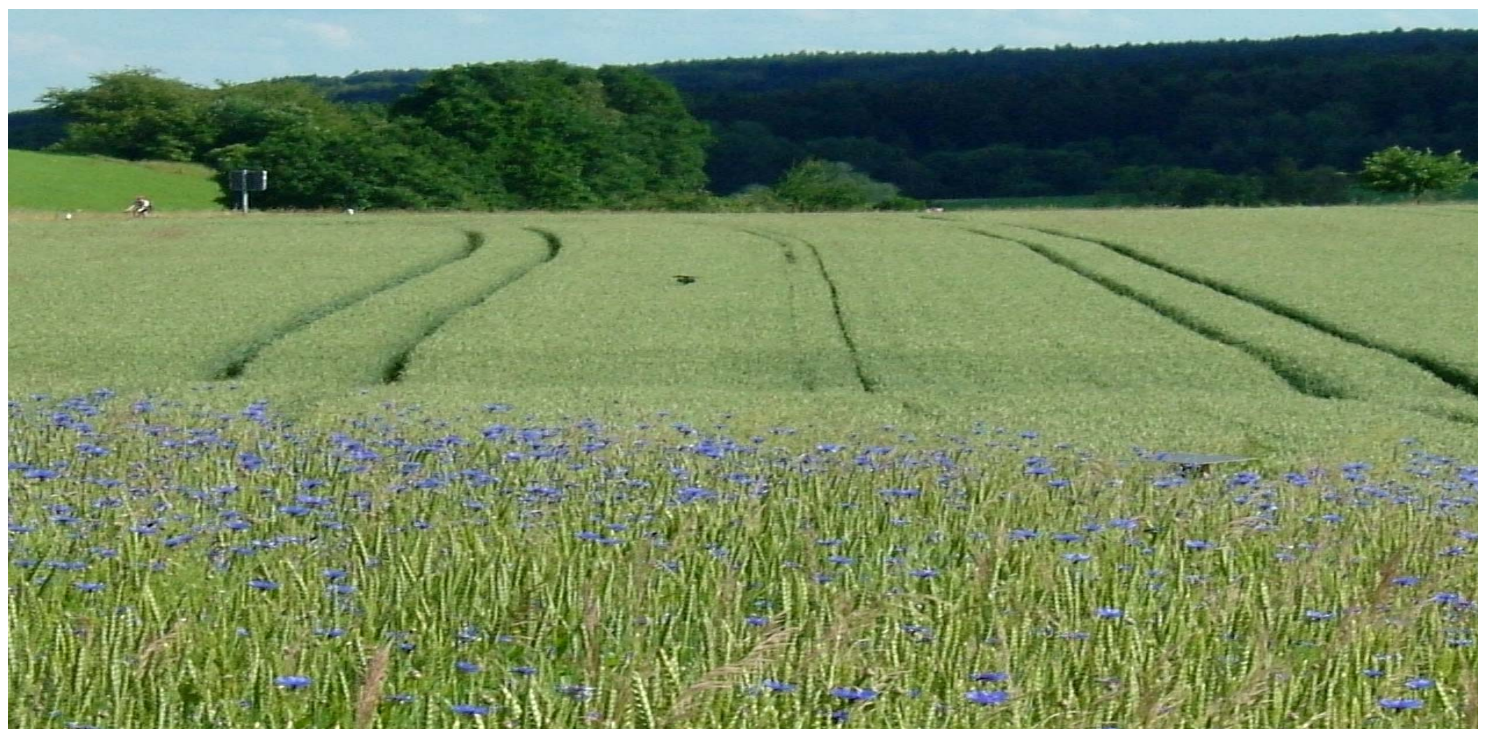

Fig. 1 Flower-rich organic wheat field and flower-poor conventional wheat field.

Multi-habitat users such as bees and wasps depend on nesting sites in noncrop habitats and food resources in often spatially separated noncrop or crop habitats (Westrich 1996, Kremen et al. 2002, Westphal et al. 2003). The declining number and size of suitable habitats and the increasing inhospitality of the landscape matrix may enhance habitat fragmentation and hamper movements between foraging and nesting sites (Saunders et al. 1991, Ricketts 2001, Fahrig 2003). However, nothing is known about how bees and wasps perceive agricultural landscapes consisting of a matrix of crop fields with interspersed noncrop habitats and differing in farming intensity. The purpose of this study was to examine how organic farming, landscape composition and dispersal corridors contribute to the diversity of bees and wasps in agricultural landscapes and how interactions with natural enemies are influenced. 


\section{Study areas}

The investigations were mainly conducted in agricultural landscapes in the vicinity of the city of Göttingen, southern Lower Saxony. For the investigations presented in chapters 2 and 3, we selected two additional study regions, the Soester Börde in North Rhine-Westphalia and the Lahn-Dill-Bergland in Hesse, to incorporate agricultural landscapes characterized by extremely high and low farming intensity. The region around Göttingen ("Leine Bergland") is characterized by a relatively small-scale distribution of intensively used farmland in the flat parts of the region and less productive areas in the hilly parts. The Soester Börde is a region of highly fertile soils which are managed intensively, mainly for producing wheat and sugar beet. The LahnDill-Bergland is divided in a small flat part with high-intensity farmland around the city of Marburg and in a large hill area characterized by low farming intensity, high proportions of grassland and small field sizes.

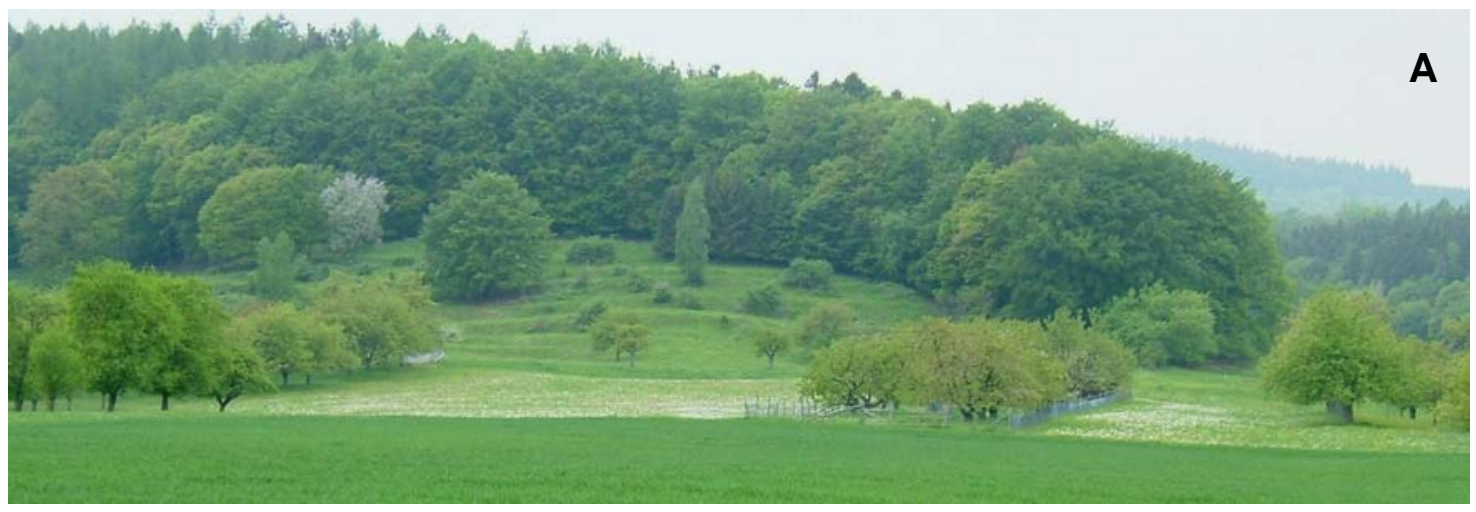

B

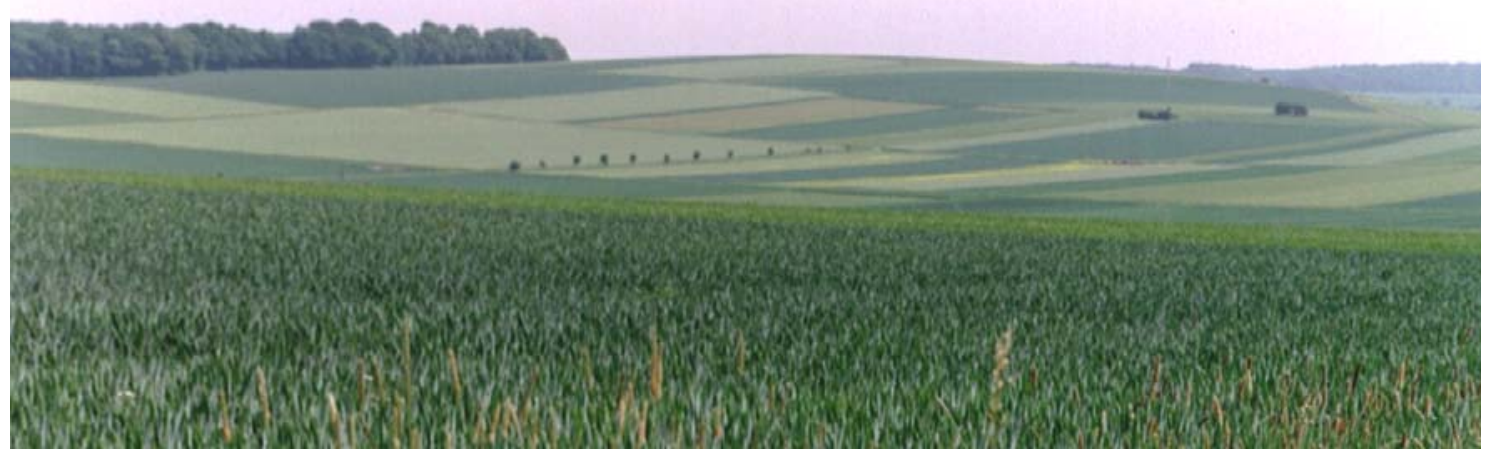

Fig. 2 (A) Heterogeneous landscape with a high proportion of noncrop habitats and high habitat diversity. (B) Homogeneous landscape with a high proportion of crop habitats and low habitat diversity. 
A

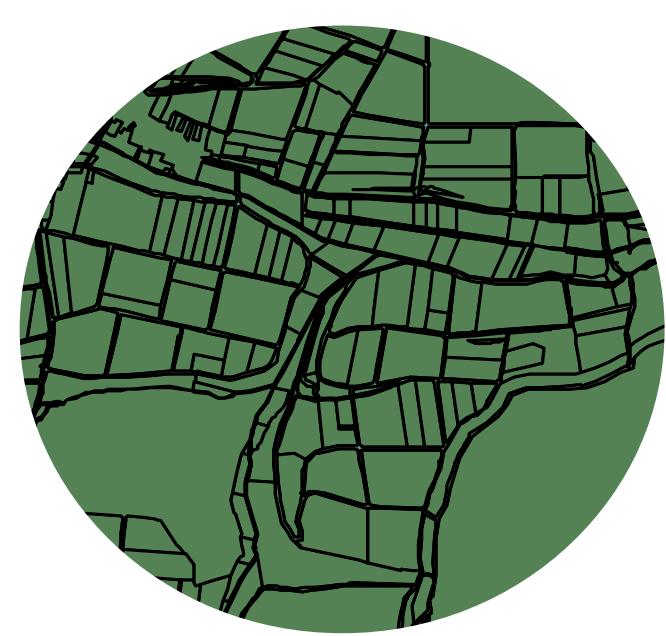

B

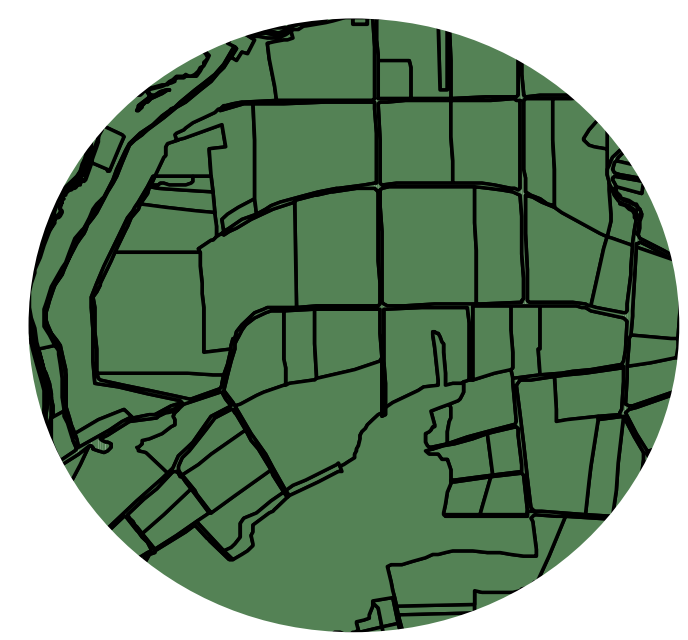

Fig. 3 Landscape sectors (1 km radius) with (A) high edge density and (B) low edge density.

All agricultural landscapes consisted of a mosaic of annual crops, permanent grassland, seminatural habitats and forest. Within each region, we selected landscapes along three gradients from heterogeneous to homogeneous landscapes. Heterogeneous landscapes were characterized by a high proportion of noncrop habitats (Fig. 2 A), high edge densities (Fig. 3 A) or high proportions of organically managed crop fields (Fig. 4 A), homogeneous landscapes by low proportions of noncrop habitats (Fig. 2 B), low edge densities (Fig. 3 B) or low proportions of organically managed crops (Fig. 4 B). For the investigations presented in chapter 2 - 4, we focused on a pair of organic and conventional wheat fields and the adjacent fallow strips within each landscape (altogether 74 organic and conventional wheat fields, 74 fallow strips). 
A

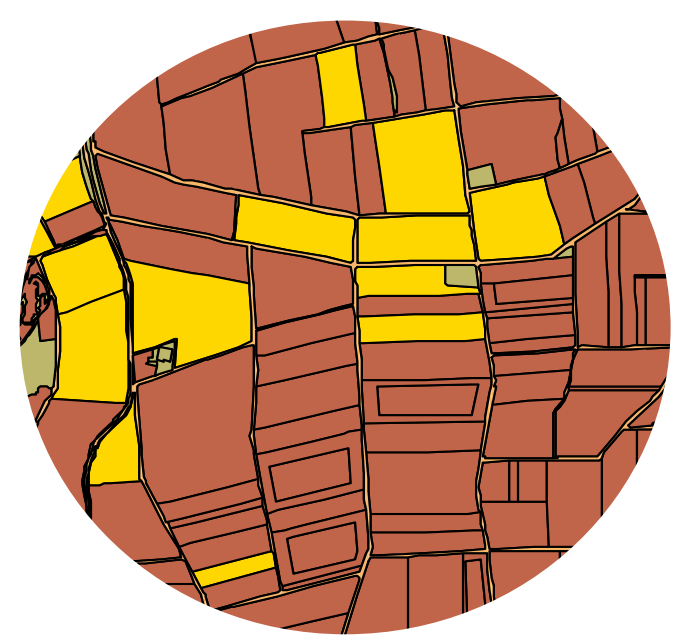

$\square$ organic crop fields

$\square$ other habitat types

settlements
B

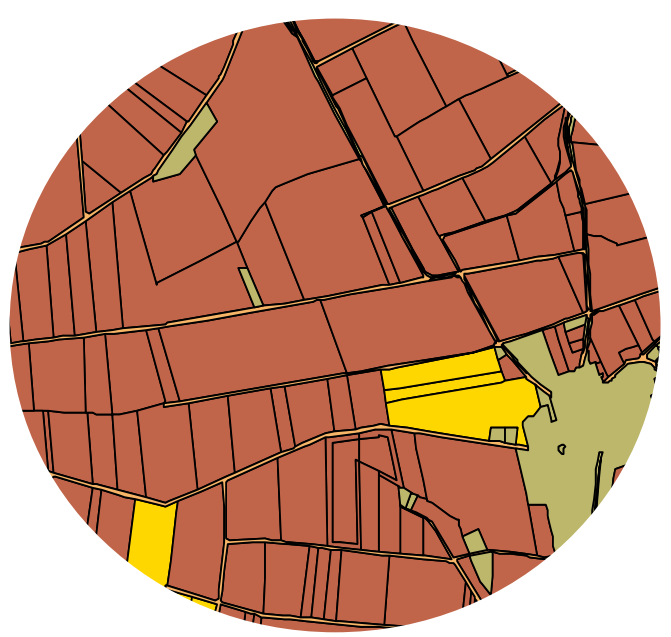

Fig. 4 Landscape sectors (1 km radius) with (A) a high proportion of organic crop fields and (B) a low proportion of organic crop fields.

The investigations in chapter 5 were conducted in twelve landscapes in the vicinity of Göttingen. For studying corridor function, we compared six treatments within each landscape at different distances from a forest edge as potential source habitat. We experimentally exposed standardized nest patches in a forest edge $(A)$, in hedges $(B, C)$ and in grass strips (D-F). Hedges and grass strips were connected with a forest edge (B, D), slightly isolated $(200 \mathrm{~m})(\mathrm{E})$ or highly isolated $(>600 \mathrm{~m})(\mathrm{C}, \mathrm{F})$. 


\section{Study organisms}

Solitary and social wild bees are considered as important pollinators in Central Europe (Corbet et al. 1991, Williams 1996). A decline of bee diversity will affect the pollination of wild plant species and many insect-pollinated crops. Pollinator populations can not be maintained by short-flowering crops alone, but also need the continuous supply of nectar and pollen in the surrounding agricultural landscapes. Fallow strips and seminatural habitats are traditionally considered as permanent refuges and sources of bees, because they provide diverse flower resources and, in contrast to annually ploughed fields, nesting sites for wild bees (Baszanak 1992, Westrich 1996, Bäckmann \& Tiainen 2002, Kremen et al. 2002, Steffan-Dewenter et al. 2002, Carvell et al. 2004, Pywell et al. 2006). About 200 of 547 bee species in Germany have been mapped in our study regions (Frommer 2001, Theunert 2003), half of them are groundnesting, $25 \%$ nest in above-ground cavities and $25 \%$ are brood parasites without own nests (Müller et al. 1997).

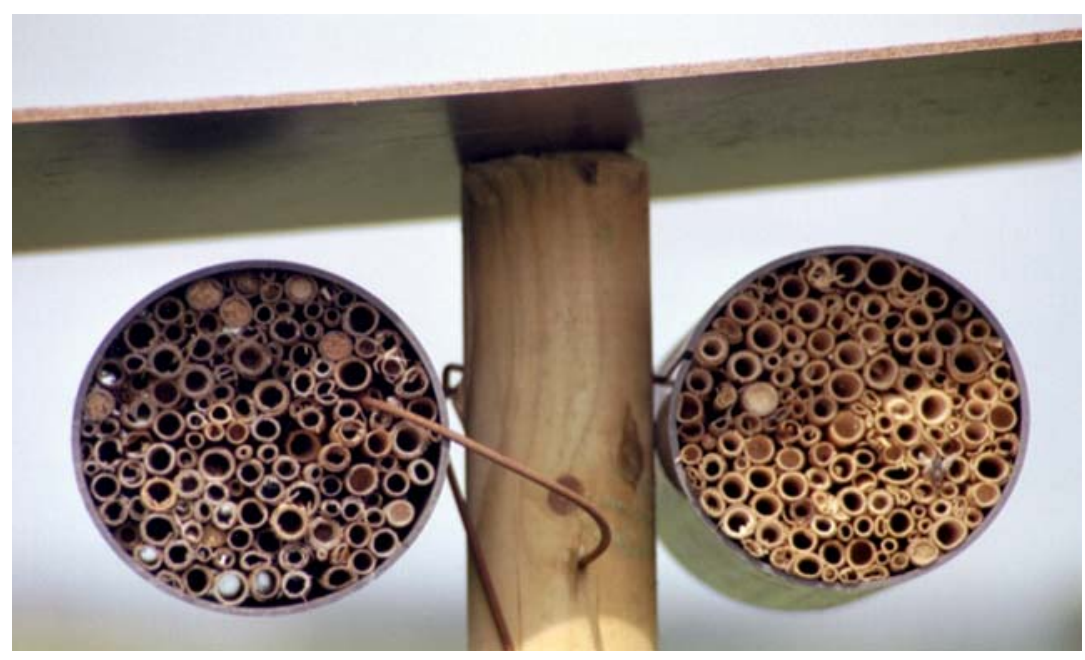

Fig. 5 Trap nest consisting of two plastic tubes filled with reed internodes. 
In addition to bee records in the field, we investigated bee and wasp communities in trap nests which enabled us to study colonization processes and interactions with natural enemies under standardized nesting conditions (Fig. 5). In Germany, 33 of the cavitynesting bee species can be recorded in trap nests, as well as 33 sphecid wasps, 17 eumenid wasps and five pompilid wasps (Gathmann \& Tscharntke 1999). Predatory wasps play an important role in ecosystems as they may contribute to biological control of pest species (Wearing \& Harris 2005) by provisioning nests with e.g. lepidopteran larvae and aphids. Trap nests consisted of plastic tubes filled with reed internodes of common reed Phragmites australis (Tscharntke et al. 1998). Within the reed internodes, solitary bees and wasps constructed nests that consist of several brood cells each containing one larva and its food provision (Fig. 6). Species richness and abundance of bees, wasps and natural enemies as well as parasitism rates can be determined in the laboratory (Gathmann \& Tscharntke 1999).

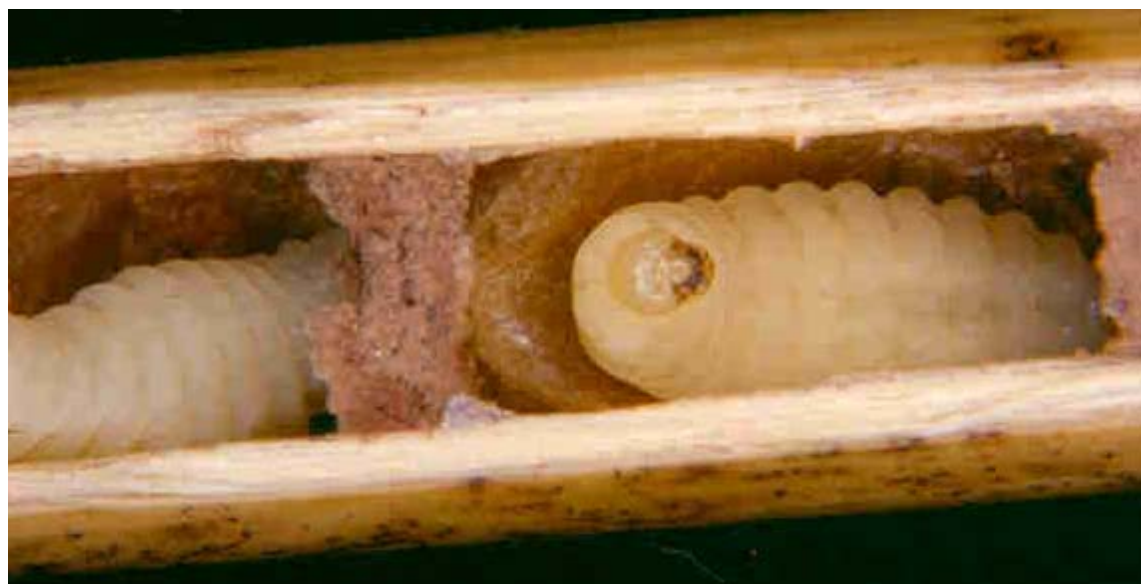

Fig. 6 Brood cells with eumenid larvae in a reed internode. Brood cells are separated by mud partitions. Photo: Susanne Schiele 


\section{Main questions}

The aim of the study was to examine how land-use intensity affects bees and wasps in agricultural landscapes at multiple spatial scales. The following questions were of major importance:

- How effective is organic farming in enhancing species richness of bees in wheat fields?

- Are patterns generated by processes at the field scale robust across landscapes and regions differing in land-use intensity? (Chapter 2)

- Do food subsidies arising from organic wheat fields enhance species richness of bees in fallow strips serving as nest habitats?

- At what spatial scales do cross-habitat fluxes connect crop and noncrop habitats? (Chapter 3)

- What is the relative importance of landscape context, organic farming and fallow strips for nest colonization of bees and wasps? (Chapter 4)

- Do corridors enhance nest colonization of solitary bees and wasps and their natural enemies in agricultural landscapes? (Chapter 5) 


\section{Results and conclusions}

Organic farming greatly enhanced flower cover, diversity of flowering plants and diversity of flower-visiting bees in wheat fields. The positive effect of organic farming was robust across regions. Interestingly, differences in bee diversity between organic and conventional fields increased with increasing proportion of crop fields in the surrounding landscape (1 $\mathrm{km}$ radius). This suggests that organic farming in homogeneous landscapes with few remaining flower-rich habitats may reach highest relative effectiveness. The interaction between farming system and landscape context clearly shows that evaluations of agri-environment schemes have to incorporate a landscape perspective (Chapter 2).

Flower resources in organic wheat fields enhanced bee communities in fallow strips at local and landscape scales. At the local scale, species richness and abundance of bees was higher in fallow strips adjacent to organic than to conventional fields. At the landscape scale, species richness and abundance of bees increased with the proportion of organic crop fields in the surrounding landscape. An increase of the proportion of organic crop fields from now $4.4 \%$ on average in Germany to $20 \%$ as aimed by the government may enhance species richness of bees in fallow strips by $54 \%$, abundance of solitary bees by $66 \%$ and abundance of bumble bees by $156 \%$. Cross-habitat fluxes apparently connected crop fields providing huge nectar and pollen resources and noncrop habitats providing nesting sites at a landscape scale. Thus, agri-environment schemes which aim to enhance biodiversity at the field scale may have landscape-wide implications for community structure and trophic interactions (Chapter 3).

Nest colonization of cavity-nesting bees and wasps was influenced by the landscape context, the farming system and the location of nests in field centres or fallow strips. Wasp colonization was highest in fallow strips independently from the farming system of the adjacent field. In contrast, bee colonization was enhanced by organic farming in both field centres and adjacent fallow strips, which did not significantly differ in bee abundance. This suggested that wasps nesting in fallow strips did not use resources provided by the adjacent field and preferred dispersing along fallow strips, whereas bees 
nesting in fallow strips benefited from resources in neighbouring organic and colonization patterns and dispersal was not restricted to linear noncrop structures. The positive effect of fallow strips on wasp colonization at the local scale was consistent with a positive effect of high edge densities providing dispersal structures at a landscape scale. A positive effect of high proportions of noncrop habitats on nest colonization of bees showed that bee communities were influenced by source habitats at a landscape scale (Chapter 4).

Grass strip corridors connecting standardized nest sites in open agricultural landscapes with a forest edge serving as source habitat enhanced nest colonization by wasps by 400 $\%$ compared to isolated nest patches. As forest edges did not serve as source habitats for bees, nest colonization of bees was not influenced by those corridors. Natural enemies largely reflected the patterns found for their hosts, and mortality rates due to natural enemies did not depend on the presence of a corridor. We conclude that grass strip corridors facilitate movements of wasps and enhance colonization of nesting sites without altering trophic interactions with natural enemies (Chapter 5).

\section{References}

Bäckmann J.-P.C. \& Tiainen J. (2002) Habitat quality of field margins in a Finnish farmland area for bumblebees (Hymenoptera: Bombus and Psithyrus). Agriculture, Ecosystems and Environment, 89, 53-68.

Banaszak, J. (1992) Strategy for conservation of wild bees in an agricultural landscape. Agriculture, Ecosystems and Environment, 40, 179-192.

Bengtsson, J., Ahnström, J. \& Weibull, A.-C. (2005) The effects of organic agriculture on biodiversity and abundance: a meta-analysis. Journal of Applied Ecology, 42, 261-269.

Benton, T.G., Vickery, J.A. \& Wilson, J.D. (2003) Farmland biodiversity: is habitat heterogeneity the key? Trends in Ecology and Evolution, 18, 182-188.

Carvell C., Meek W.R., Pywell R.F. \& Nowakowski M. (2004) The response of foraging bumblebees to successional change in newly created arable field margins. Biological Conservation, 118, 327-339. 
Clough Y., Kruess A., Kleijn D. \& Tscharntke T. (2005) Spider diversity in cereal fields: comparing factors at local, landscape and regional scales. Journal of Biogeography, 32, 2007-2014.

Corbet, S.A., Williams, I.H. \& Osborne J.L. (1991) Bees and the pollination of crops and wild flowers in the European Community. Bee World, 72, 47-59.

Fahrig L. (2003) Effects of habitat fragmentation on biodiversity. Annual Review of Ecology, Evolution, and Systematics, 34, 487-515.

Frommer U. (2001) Bestandsaufnahme der Bienenfauna im mittleren Hessen (Hymenoptera, Apidae). Naturwissenschaftlicher Verein Darmstadt - Bericht N.F., 24, 129-191.

Hole, D.G., Perkins, A.J., Wilson, J.D., Alexander, I.H., Grice, P.V. \& Evans, A.D. (2005) Does organic farming benefit biodiversity? Biological Conservation, 122, 113-130.

Jonsen I.D. \& Fahrig L. (1997) Response of generalist and specialist insect herbivores to landscape spatial structure. Landscape Ecology, 12, 185-197.

Kareiva P. (1990) Population-dynamics in spatially complex environments - theory and data. Philosophical Transactions of the Royal Society of London Series B-Biological Sciences, 330, $175-190$

Krebs, J.R., Wilson, J.D., Bradbury, R.B., \& Siriwardena, G.M. (1999) The second Silent Spring. Nature, 400, 611-612.

Kremen, C., Williams, N.M., Bugg, R.L., Fay, J.P. \& Thorp, R.W. (2004) The area requirements of an ecosystem service: crop pollination by native bee communities in California. Ecology Letters, 7, 1109-1119.

Kremen, C., Williams, N.M. \& Thorp, R.W. (2002) Crop pollination from native bees at risk from agricultural intensification. Proceedings of the National Academy of Sciences of the USA, 99, $16812-16816$.

Müller, A., Krebs, A. \& Amiet, F. (1997) Bienen: Mitteleuropäische Gattungen, Lebensweise, Beobachtung. Naturbuch Verlag, München.

Pywell R.F., Warman E.A., Hulmes L., Hulmes S., Nuttall P., Sparks T.H., Critchley C.N.R., Sherwood A. (2006) Effectiveness of new agri-environment schemes in providing foraging resources for bumblebees in intensively farmed landscapes. Biological Conservation, 129, 192-206.

Ricketts, T.H. (2001) The matrix matters: effective isolation in fragmented landscapes. American Naturalist, 158, 87-99. 
Saunders, D.A., Hobbs, R.J., \& Margules, C.R. (1991) Biological consequences of ecosystem fragmentation - a review. Conservation Biology, 5, 18-32.

Steffan-Dewenter, I., Münzenberg, U., Bürger, C., Thies, C. \& Tscharntke, T. (2002) Scale-dependent effects of landscape context on three pollinator guilds. Ecology, 83, 1421-1432.

Stoate, C., Boatman, N.D., Borralho, R.J., Carvalho, C.R., de Snoo, G.R. \& Eden, P. (2001) Ecological impacts of arable intensification in Europe. Journal of Environmental Management, 63, 337-365.

Theunert R. (2003) Atlas zur Verbreitung der Wildbienen (Hym.: Apidae) in Niedersachsen und Bremen (1973-2002). Ökologieconsult, Hohenhameln.

Tilman, D., Fargione, J., Wolff, B., D'Antonio, C., Dobson, A., Howarth, R., Schindler, D., Schlesinger, W.H., Simberloff, D. \& Swackhamer, D. (2001) Forecasting agriculturally driven global environmental change. Science, 292, 281-284.

Tscharntke, T., Gathmann, A., \& Steffan-Dewenter, I. (1998) Bioindication using trap-nesting bees, wasps and parasitoids: community structure and interactions. Journal of Applied Ecology, 35, 708-719.

Tscharntke T., Klein A.M., Kruess A., Steffan-Dewenter I., Thies C. (2005) Landscape perspectives on agricultural intensification and biodiversity - ecosystem service management. Ecology Letters, 8, $857-874$

Wearing C.H. \& Harris A.C. (2005) Evaluation of the predatory wasp, Ancistrocerus gazella, for biological control of leafrollers in Otago fruit crops. II. Wasp phenology and seasonal changes in prey composition. Biocontrol Science and Technology, 15, 281-298.

Weibull, A.-C., Östman, Ö. \& Granquist, Å. (2003) Species richness in agroecosystems: the effect of landscape, habitat and farm management. Biodiversity and Conservation, 12, 1335-1355.

Westphal C., Steffan-Dewenter I. \& Tscharntke T. (2003) Mass flowering crops enhance pollinator densities at a landscape scale. Ecology Letters, 6, 961-965.

Westrich, P. (1996) Habitat requirements of central European bees and the problems of partial habitats. The conservation of bees (ed. A. Matheson, S.L. Buchmann, C. O'Toole, P. Westrich \& I.H. Williams), pp. 1-16. Academic Press, London.

Williams, I.H. (1996) Aspects of bee diversity and crop pollination in the European Union. The conservation of bees (ed. A. Matheson, S.L. Buchmann, C. O’Toole, P. Westrich \& I.H. Williams), pp. 63-80. Academic Press, London. 


\title{
Chapter 2
}

\section{Diversity of flower-visiting bees in cereal fields: effects of farming system, landscape composition and regional context}

\begin{abstract}
1. Agri-environment schemes promote organic farming in an attempt to reduce the negative effects of agricultural intensification on farmland biodiversity and ecosystem services such as pollination. Farming system, landscape context and regional differences may all influence biodiversity, but their relative impact and possible interactions have been little explored.

2. The study was performed in three spatially separated regions $(150 \mathrm{~km}$ distance, $400-$ $500 \mathrm{~km}^{2}$ per region) differing in regional land-use intensity. Within each region seven pairs of conventionally and organically cultivated wheat fields (mean size 4 ha) were selected to encompass a gradient from heterogeneous to homogeneous landscape context within $1 \mathrm{~km}$ radius around each field (altogether 42 study fields).

3. Farming system had the greatest influence resulting in higher bee diversity, flower cover and diversity of flowering plants in organic compared to conventional fields. Bee diversity was related to flower cover and diversity of flowering plants suggesting plantmediated effects of the farming system on bee diversity.

4. Differences in bee diversity between organic and conventional fields increased with the proportion of arable crops in the surrounding landscape, thereby indicating that processes at the landscape level modified the effectiveness of organic farming. Similar patterns for flower cover and diversity of flowering plants suggest that landscape effects on bee diversity were mainly resource-mediated. After statistically removing the variance explained by flower parameters, residual bee diversity increased with increasing landscape heterogeneity.
\end{abstract}


5. Bee diversity differed between the three regions, but the effects of farming systems and landscape context were independent from regional differences.

6. Synthesis and applications. Bee diversity in wheat fields was mainly influenced by farming system, but understanding of local bee diversity needs to incorporate a landscape and a regional perspective. The consistency of the results in three regions provides a reliable basis for management decisions. Agri-environment schemes promoting organic farming in homogeneous landscapes with few remaining flower-rich habitats could reach highest relative effectiveness. However, while organic farming could help to sustain pollination services by generalist bees in agricultural landscapes, other measurements are required to conserve more specialised bee species in seminatural habitats.

\section{Keywords}

agri-environment schemes, biodiversity, flowering plants, landscape structure, organic farming, pollination, spatial scale, weeds, winter wheat 


\section{Introduction}

Agricultural intensification at different spatial scales has caused a significant decline in farmland biodiversity (Krebs et al. 1999). During the last decades, cultivation of annual crops has expanded at the cost of noncrop habitats such as extensive grasslands, fallows, hedges and field margins (Tilman et al. 2001, Benton, Vickery \& Wilson 2003). Noncrop habitats provide dispersal corridors and habitat islands required by many species as refuges and feeding areas (Stoate et al. 2001). Several studies have shown habitat fragmentation and decreasing landscape heterogeneity to be associated with a loss of biodiversity in agricultural landscapes (Jonsen \& Fahrig 1997, Steffan-Dewenter \& Tscharntke 1999, Steffan-Dewenter et al. 2002, Weibull, Östman \& Granquist 2003). Additionally, ecological functions such as predation of pest insects and pollination of crops suffer from decreasing landscape heterogeneity (Thies \& Tscharntke 1999, Richards 2001, Kremen, Williams \& Thorp 2002, Tilman et al. 2002, Kremen et al. 2004, Tscharntke et al. 2005).

At the field scale, agricultural intensification has affected biodiversity by changing farming practices (Benton, Vickery \& Wilson 2003). High-input arable systems with increased applications of fertilisers and pesticides have adverse effects on biodiversity (Wilson et al. 1999). More extensive systems such as organic farming aim to mitigate the negative impacts of modern agriculture and to enhance biodiversity (Krebs et al. 1999, Reganold, Glover \& Andrews 2001, Tybirk, Alroe \& Frederiksen 2004). Several studies show positive effects of organic farming relative to conventional agriculture for plants (Hald 1999, Hyvönen et al. 2003, Bengtsson, Ahnström \& Weibull 2005), whereas arthropods appear to respond ambiguously to organic cropping, showing negative, positive or no effects (reviewed in Hole et al. 2005). Contrasting findings may arise when differences between farming systems result from associated differences in landscapes rather than directly from farming practices (Bengtsson, Ahnström \& Weibull 2005). Although Krebs et al. (1999) suggest that biodiversity in agroecosystems depends on both landscape heterogeneity and farm management, studies that take landscape variables into account are rare. The few studies performed at a larger scale than the field scale found that the landscape context can modify the influence of organic farming on plants (Roschewitz et al. 2005) or may be even more important for the 
diversity of bees, butterflies, carabids and spiders than the local farming system (Kremen, Williams \& Thorp 2002, Weibull, Bengtsson \& Nohlgren 2000, Weibull, Östman \& Granquist 2003, Schmidt et al. 2005). In homogeneous landscapes, differences in biodiversity between organic and conventional fields may be larger, because organic fields compensate for the missing noncrop habitats (Bengtsson, Ahnström \& Weibull 2005). On the other hand, the isolation of organic fields in homogeneous landscapes may be too high and the species pool too small to allow a response of biodiversity to organic farming (Tscharntke et al. 2005). In the latter scenario, the positive impact of organic farming will be smaller in the most intensively used homogeneous landscapes (Kleijn \& Sutherland 2003). Modifications of local patterns may not only result from surrounding landscapes, but also from even larger spatial scales. Geographical regions might differ regarding the regional species pool, large scale patterns of land-use or climatic and soil conditions. Further political and administrative regulations which differ among regions might affect the implementation of agri-environmental schemes and agricultural management practises (Wilson 1994).

Solitary and social wild bees are considered as important pollinators in Central Europe (Corbet, Williams \& Osborne 1991, Williams 1996). A decline of bee diversity will affect the pollination of wild plant species and many insect-pollinated crops. Pollinator populations can not be maintained by these short-flowering crops alone, but also need the continuous supply of nectar and pollen in the surrounding agricultural landscapes.

The objective of our study was to examine the effectiveness of agri-environmental schemes promoting organic farming on bee diversity as a functionally important and threatened species group in agricultural landscapes. We surveyed bees in winter wheat, which is the most important arable crop in Germany. Although wheat itself does not contain pollen or nectar, wheat fields can provide flower resources due to a species-rich noncrop flora (Roschewitz et al. 2005). Using a paired-field approach (organic vs. conventional), we incorporated a landscape scale and a regional scale in the study. We compared different regions to examine whether patterns generated by processes acting at local and landscape scales were robust across regions. In particular, we were interested in the relative contribution of effects mediated by changes in flower resource availability compared to other effects related to farming system and landscape context. 


\section{Methods}

\section{Study regions and study sites}

The study was conducted in 2003 in three regions belonging to three different federal states in Germany (Leine Bergland/Lower-Saxony, Lahn-Dill-Bergland/Hesse and Soester Boerde/North Rhine-Westphalia). The regions were situated about $150 \mathrm{~km}$ from each other. They were between 400 and $500 \mathrm{~km}^{2}$ in size. Regions differed in the largescale land-use intensity, as well as in a number of other factors (Table 1). The Soester Boerde $\left(51^{\circ} 35^{\prime} 00^{\prime \prime} \mathrm{N} 008^{\circ} 07^{\prime} 00^{\prime \prime} \mathrm{E}\right)$ is characterised by intensive agriculture on fertile loess soils which are mainly used for producing wheat and sugar beet. The Leine Bergland $\left(51^{\circ} 32^{\prime} 00^{\prime \prime} \mathrm{N} 009^{\circ} 56^{\prime} 00^{\prime \prime} \mathrm{E}\right)$ is a region with very productive areas on fertile soils in flat parts of the region which alternate with more diverse agricultural landscapes in hilly parts. The Lahn-Dill-Bergland (50 49' $\left.00^{\prime \prime} \mathrm{N} 008^{\circ} 46^{\prime} 00^{\prime \prime} \mathrm{E}\right)$ is divided in a large hill area with high proportions of grasslands and rather small fields, and in a flat and homogeneous part with intensively used farmland.

Table 1: Elevation, climate factors, land-use and crop data for the three regions Leine Bergland, LahnDill-Bergland and Soester Boerde in 2003.

\begin{tabular}{lccc}
\hline \hline & Leine Bergland & Lahn-Dill-Bergland & Soester Boerde \\
\hline Elevation $(\mathrm{m}) \dagger$ & $155-340$ & $100-496$ & $70-320$ \\
Mean temperature $\left({ }^{\circ} \mathrm{C}\right)$ & 8.7 & 9.4 & 9.3 \\
Precipitation $(\mathrm{mm} /$ year $)$ & 550 & 704 & 693 \\
$\%$ grassland & 5.3 & 16.8 & 8.9 \\
$\%$ forest & 31.3 & 42.8 & 16.2 \\
$\%$ arable land & 52.1 & 23.5 & 61.8 \\
$\%$ crop fields in $1 \mathrm{~km}$ radius & 62.7 & 46.8 & 64.1 \\
$\%$ seminatural habitats & 2.6 & 1.5 & 4.4 \\
$\%$ annual fallows & 5.1 & 1.8 & 3.2 \\
Mean winter wheat yield $(100 \mathrm{~kg} / \mathrm{ha})$ & 62.0 & 58.1 & 62.8 \\
\hline \hline
\end{tabular}

Note: Large-scale land-use (\% arable land, \% grassland, $\%$ forest) was calculated for circles with $10 \mathrm{~km}$ radius around the study sites. Average \% crop fields, seminatural habitats and annual fallows were calculated for the 14 landscape sectors per region ( $1 \mathrm{~km}$ radius).

$\uparrow$ Minimum and maximum elevations of the study sites are shown. 
In total, 42 winter wheat fields were studied, with seven organic and seven conventional fields in each region. Wheat is the most important arable crop in Germany, as well as in our study regions. About $60 \%$ of the total arable area in Germany is cultivated with cereals, and $45 \%$ of this area is cultivated with wheat (Statistisches Bundesamt 2004). The 21 organic farmers involved cultivated winter wheat according to the European Union regulation 2092/91/EEC, which prohibits among others the use of synthetic fertilisers and pesticides (Table 2). Each organic field was paired with the first nearby conventional winter wheat field for a comparison which controlled for differences in abiotic conditions and landscape context. Distances between fields within a pair ranged from $0 \mathrm{~m}$ to $600 \mathrm{~m}$. Field sizes did not differ between the two farming types ( $\mathrm{t}$-tests for paired samples, Table 2).

Table 2: Agricultural practices and yields in the study year, field sizes and landscape characteristics for 21 conventional and 21 organic winter wheat fields (= 42 farmers). Means \pm standard deviations, minima and maxima are given.

\begin{tabular}{lcc}
\hline \hline & Conventional & Organic \\
\hline Use of insecticides & 9 farmers & - \\
Use of herbicides against broadleaves & all farmers & - \\
Weed control by harrowing or hoeing & 1 farmer & 17 farmers \\
Use of synthetic fertiliser & 20 farmers & - \\
Use of organic fertiliser & 9 farmers & 8 farmers \\
Legumes in crop rotation & - & 15 farmers \\
Length of crop rotation (years) & $3.45 \pm 0.69(2-5)$ & $4.25 \pm 1.25(3-7)$ \\
Fertilisation (kg N/ha) & $175.1 \pm 34.01(125-260)$ & $38.4 \pm 55.63(0-180)$ \\
Winter wheat yield (100 kg/ha) & $75.9 \pm 18.4(42-98)$ & $45.9 \pm 10.2(25-60)$ \\
Field size (ha) & $5.1 \pm 3.5(0.7-11.3)$ & $3.3 \pm 3.0(0.6-12.5)$ \\
$\%$ crop fields in $1 \mathrm{~km}$ radius & $58.1 \pm 19.9(17-85)$ & $57.6 \pm 19.2(17-86)$ \\
\hline \hline
\end{tabular}




\section{Surveying bees and flowering plants}

Bees (Apiformes) were recorded at four dates between May and July along transects 95 $\mathrm{m}$ long and $1 \mathrm{~m}$ wide in the field centre and the field edge for $15 \mathrm{~min}$ per transect and date $(15 \mathrm{~min} \times 2 \times 4=120 \mathrm{~min}$ per field in total). The edge transects were put $1 \mathrm{~m}$ into the cereal field along the field edge. All bees were collected for identification in the laboratory. Fields of a pair were sampled directly one after the other, between 10:00 and 18:00 at convenient sunny weather conditions (temperature $>18^{\circ} \mathrm{C}$, cloud cover $<30$ $\%$, low wind speeds $<3 \mathrm{Bft}$ ). The number of bee species used for statistical analysis is the accumulated number caught within the study period. Data of the field centre and the field edge were pooled for the analysis. There was no significant difference in bee diversity between the field centre and edge in organic fields ( $\mathrm{t}$-test for paired samples: $\mathrm{P}=0.074)$. In conventional fields, bee diversity was higher in the field edge than in the field centre $(p=0.009)$. The field edge represented a relatively small area of the total field only. Thus, we rather tended to overestimate the value of conventional fields for bees.

All plant species flowering during the survey were recorded four times in a $1 \mathrm{~m}$ wide sector along the bee transects. The number of flowering plant species in our analyses is the accumulated number recorded within the study period. The flower cover was estimated for each species at four dates in a $1 \mathrm{~m}$ wide sector along the bee transects. Flower cover is the percent cover of flower corollas per area ground surface. Flower cover values were summarised for each transect and averaged over transects and the four surveys.

\section{Quantifying landscape context}

The surrounding landscape was characterised for each field within a circle of $1 \mathrm{~km}$ radius around the field centre. This radius was chosen because solitary wild bees, which provide most of the recorded bee species, are known to be influenced by the landscape on small spatial scales up to $1 \mathrm{~km}$ (Gathmann \& Tscharntke 2002, Steffan-Dewenter et al. 2002). Field inspections were made to record the areas of different habitat types in these landscape sectors on the base of official topographical maps (DGK 1:5000). Proportions of different habitat types, edge density and Shannon-index of habitat 
diversity were calculated for the landscape sectors using Geographic Information Systems (GIS; Topol 4.506, Gesellschaft für digitale Erdbeobachtung und Geoinformation mbH, Göttingen, Germany and ARC/View 3.2., ESRI Geoinformatik $\mathrm{GmbH}$, Hannover, Germany). Sectors of different field pairs did not overlap, as the distance between pairs within a region ranged from $3 \mathrm{~km}$ to $45 \mathrm{~km}$. We used the proportion of annual crop fields as a homogeneous indicator for landscape complexity because of its negative correlation to the Shannon-index of habitat diversity and the proportions of grassland and forest (Spearman rank correlations, $\mathrm{n}=21, \mathrm{P}<0.01$ ). The proportion of crop fields did not significantly differ between the three study regions (Tab. 1, t-test: $\mathrm{P}=0.174$ ) and between landscape sectors around organic and those around conventional fields (Tab. 2, t-test for paired samples: $\mathrm{P}=0.770$ ). The proportion of crop fields was negatively related to the altitude of study sites, but pre-analyses did not show any relationship between altitude and bee diversity or flower availability.

\section{Statistics}

We used linear mixed-effects models to determine effects acting at three spatial scales on flower cover, diversity of flowering plants and bee diversity (Pinheiro \& Bates 2000). We tested for significance of fixed effects (farming system: organic vs. conventional, landscape context: proportion of crop fields, region) and their interactions. Neighbouring organic and conventional fields were grouped within pairs by adding landscape as random block factor. The landscape parameter was tested on the level of the field pairs $(n=21)$, because landscape sectors of neighbouring fields were not independent. Wald-type F-tests (Type I) were used for the factor selection. Fixed factors and interactions that did not contribute to the model with $\mathrm{P}<0.05$ were removed by a stepwise backward procedure from the full model. Non-significant factors that were part of significant interactions were not removed. We also referred to ecologically meaningful marginally significant factors $(0.05<\mathrm{P}<0.10)$. Differences between regions were further inspected using one-way ANOVA and Tukey HSD post-hoc tests on the data averaged over field pairs.

Multiple linear regression models were used to analyse the relative importance of flower cover and diversity of flowering plants for bee diversity. By including diversity 
of flowering plants and flower cover into the linear mixed-effects model for bee diversity, we tested for other effects of farming system, landscape context and region after accounting for the variance explained by flower parameters. We transformed the number of bee species $(\log 10(x+1))$ and the percentage values of flower cover (arcsine-square-root-transformation) (Sokal \& Rohlf 1995). All statistical analyses were performed using R (R Development Core Team 2004).

Bee diversity was correlated with individual numbers in organic and conventional fields. We checked for a possible bias of sample size in our analysis of diversity by computing first-order jackknife estimates of species richness (EstimateS, Colwell 2005). Estimates were based upon data from the four sample dates. Despite season-dependent species turnover, observed bee species richness was $66 \%$ of the estimated species richness in conventional fields, and $79 \%$ in organic fields. Results of analyses performed on species richness estimates did not differ from results based on raw data. In addition, we computed estimates based upon data from five subsamples of the fourth sample date to avoid effects of season-dependent species turnover. Sampling effort proved to be sufficient, with observed bee species richness being between $100 \%$ of the estimated species richness in conventional fields and $87 \%$ in organic fields.

\section{Results}

\section{Species richness of bees and flowering plants}

In total, 1507 bee individuals were recorded (167 solitary bees, 693 bumble bees, 647 honey bees). We identified 37 bee species from twelve genera. The most species-rich genera were Andrena (15 species), Bombus (7 species), Nomada (4 species) and Lasioglossum (3 species). We found 31 bee species in organic fields and 16 in conventional fields. Six species were found only in conventional fields and 21 species only in organic fields. We recorded 51 species of plants flowering during the study period. We observed only polylectic bee species using pollen resources from different plant families, but no specialised bee species depending on certain plant families as pollen resources. 


\section{Effects of farming system, landscape context and region}

Bee diversity was related to factors at all three spatial scales (local, landscape and regional scale). The local scale factor farming system (organic vs. conventional) had the highest impact on bee diversity (Table 3). Bee diversity was generally higher in organic than in conventional fields (Fig. 1a). A significant interaction between farming system and landscape context showed that differences in bee diversity between organic and conventional fields depended on landscape context (Table 3). The positive effect of organic farming was highest in homogeneous landscapes (Fig. 1b). Bee diversity was significantly higher in the region Leine Bergland than in the Soester Boerde. The LahnDill-Bergland did not significantly differ in bee diversity from the other regions. Regional differences did not interact with the effects of farming system or landscape context.

Table 3: Final linear mixed-effects models describing the effects of farming system (organic vs. conventional), landscape context ( $\%$ crop fields in $1 \mathrm{~km}$ radius) and region as well as their interactions on bee diversity, diversity of flowering plants and mean flower cover in 42 wheat fields. Non-significant factors which were part of significant interactions were not removed.

\begin{tabular}{lrrr}
\hline \hline & DF & F & \multicolumn{1}{c}{$\mathrm{P}$} \\
\hline Number of bee species & 1,17 & 63.64 & $<0.001$ \\
Farming system & 1,17 & 0.78 & $\mathrm{~ns}$ \\
Landscape context & 2,17 & 3.62 & 0.049 \\
Region & 1,17 & 6.99 & 0.017 \\
Farming system x Landscape context & & & \\
& 1,19 & 97.92 & \\
Number of flowering plant species & 1,19 & 0.50 & $\mathrm{~ns}$ \\
Farming system & 1,19 & 3.82 & 0.066 \\
Landscape context & & & \\
Farming system x Landscape context & 1,19 & 20.00 & 0.001 \\
\% Flower cover & 1,19 & 5.68 & 0.028 \\
Farming system & 1,19 & 5.73 & 0.027 \\
Landscape context & & & \\
Farming system x Landscape context & & & \\
\hline \hline
\end{tabular}


Diversity of flowering plants and flower cover were higher in organic than in conventional fields (Table 3, Figs 1c \& 1e). Differences in the diversity of flowering plants and flower cover between organic and conventional fields were largest in homogenous landscapes (Figs 1d \& 1f). Flower cover increased significantly in homogeneous landscapes mainly because of three dominant species, Matricaria chamomilla L., Tripleurospermum inodorum (L.) Schultz Bip. and Sinapis arvensis L..

(a)
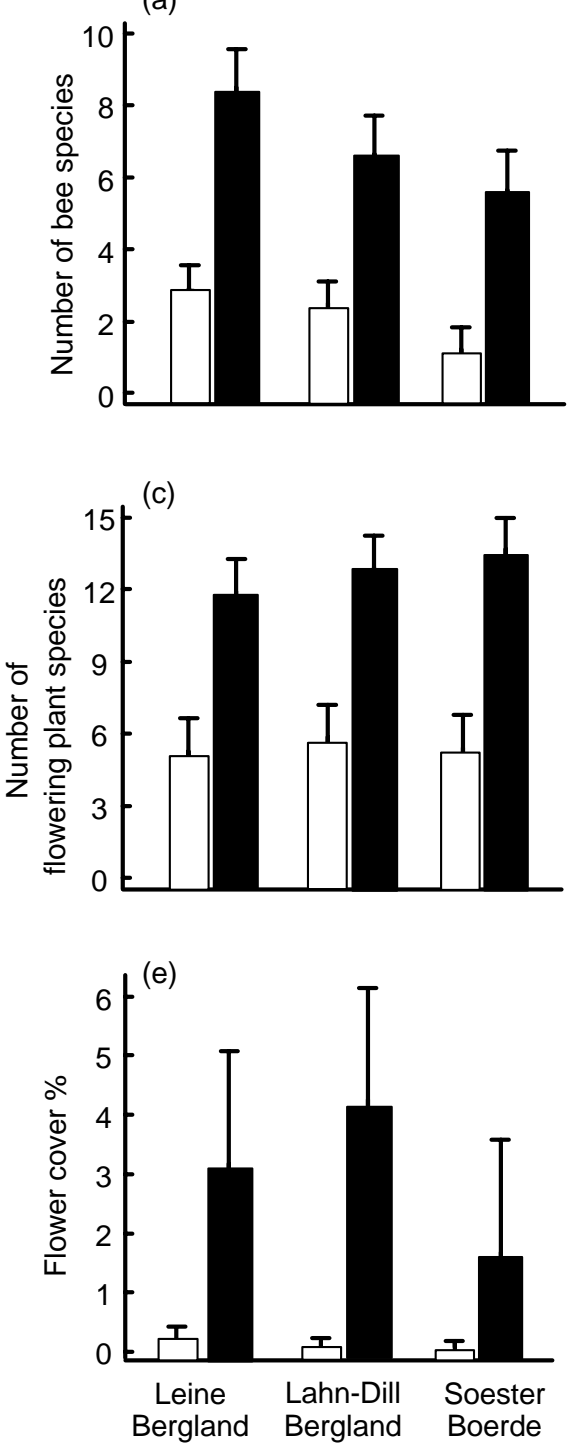

(b)
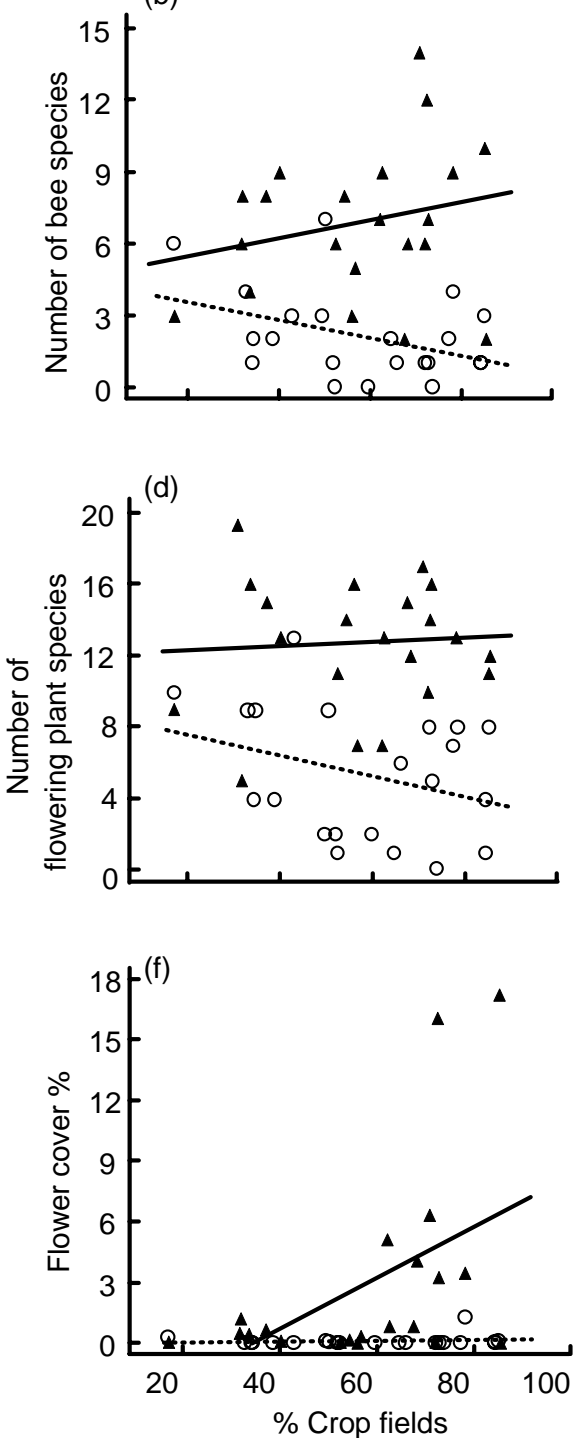

Fig. 1 Means and standard errors of the number of bee species, flowering plant species and \% flower cover in conventional (white bars) and organic fields (black bars) in three regions (a, c, e). Effects of landscape context ( $\%$ crop fields in $1 \mathrm{~km}$ radius) on the number of bee species, number of flowering plant species and the $\%$ flower cover in organic vs. conventional farming systems (b, d, f). Organic fields: triangles and solid lines, conventional fields: points and dashed lines. Results are from mixed-effects models (see Table 3). 


\section{Relative importance of plant-mediated and other effects on bee diversity}

Diversity of flowering plants and flower cover were correlated in conventional, but not in organic fields (Spearman Rank Correlation: conventional fields: $R=0.618$, $\mathrm{P}=0.006$, organic fields: $\mathrm{R}=0.166, \mathrm{P}=0.457$ ). In multiple regression analyses, we tested the importance of diversity and cover of flowering plants for bee diversity. Bee diversity in conventional fields mainly depended on the diversity of flowering plants (diversity of flowering plants: $\mathrm{F}=12.63, \mathrm{P}=0.002$, flower cover: $\mathrm{F}=3.94, \mathrm{P}=0.063$ ). Bee diversity in organic fields depended on flower cover only (diversity of flowering plants: $F=0.27, P=0.613$, flower cover: $F=9.81, P=0.006)$. All significant relationships between bee diversity, diversity of flowering plants and flower cover from simple regressions are shown in Fig. 2.
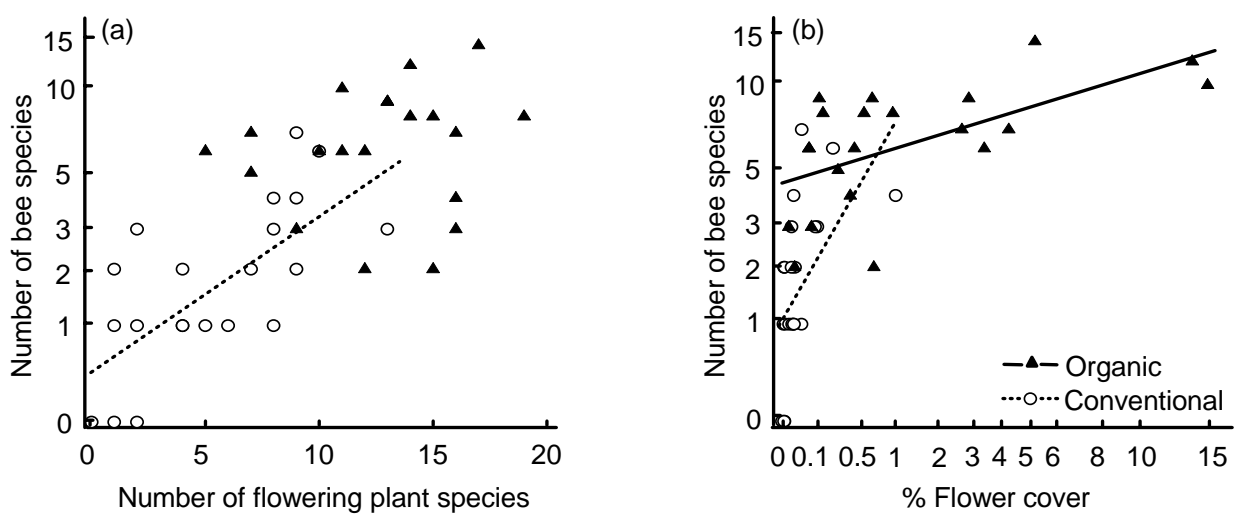

Fig. 2 Relationship between bee species number and (a) number of flowering plant species and (b) \% flower cover in conventional and organic fields. Results are from simple regression analyses. Regression lines are shown for significant regressions only. (a) organic: $\mathrm{R}=0.01, \mathrm{~F}=0.38, \mathrm{P}=0.543$, conventional: $\mathrm{R}=0.70, \mathrm{~F}=18.1, \mathrm{P}<0.001$, (b) organic: $\mathrm{R}=0.60, \mathrm{~F}=10.5, \mathrm{P}=0.004$, conventional: $\mathrm{R}=0.53, \mathrm{~F}=7.6, \mathrm{P}=0.013$.

Additionally, we tested for the relative importance of flower resource availability and other effects of farming practise and landscape context. In a linear mixed-effects model we included first diversity of flowering plants and flower cover, and then farming system, landscape context and region. After removing variance explained by the flower parameters (diversity of flowering plants: $\mathrm{F}=88.12, \mathrm{P}<0.001$, flower cover: $\mathrm{F}=12.10$, $\mathrm{P}=0.003)$, the other factors contributed significantly or marginally significantly to the model (farming system: $\mathrm{F}=3.27, \mathrm{P}=0.090$, landscape context: $\mathrm{F}=4.74, \mathrm{P}=0.045$, region: $\mathrm{F}=7.21, \mathrm{P}=0.006)$. 


\section{Discussion}

The main objective of our study was to evaluate the effectiveness of a widespread agrienvironment scheme in promoting diversity of bees as a functionally important insect group. In addition to a comparison of farming systems, our approach took the landscape and regional context of fields into account. Our results indicate that organic farming increased bee diversity by enhancing flower availability. In addition to the effect of farming system, both bee diversity and flower resources were also influenced by the landscape context. Although regions differed in total bee diversity, effects of farming system and landscape context were consistent over the three studied regions.

\section{Effects of farming systems on plant and bee diversity}

The diversity of flower-visiting bees in wheat fields greatly depended on the farming system with higher bee diversity in organic than in conventional fields. An obvious reason for the differences between farming systems is the absence of agrochemical applications in organic fields. Herbicides reduce the cover and diversity of flowering weed species in conventional fields (Bengtsson, Ahnström \& Weibull 2005, Roschewitz et al. 2005) and therewith the resource availability for flower-visiting insects. Flower cover and diversity of flowering plants were positively related to bee diversity in our study, and have also been shown to benefit other species groups (Hole et al. 2005). Additionally, we found marginal differences between farming systems after removing variance explained by flower resources. This might be related to the ban on insecticides in organic fields, because insecticides are considered as an important direct cause of bee mortality in agricultural regions (Thompson 2001, 2003). The low level of significance of this effect in our study might be explained by the fact that only nine of 21 conventional farmers applied insecticides.

Thus, organic farming converted wheat fields into insecticide-free and flower-rich foraging habitats. Other studies have suggested that arable fields might provide richer food resources than seminatural habitats, thereby complementing habitat requirements of bees settling in non-arable habitats (Banaszak 1992). For example, bumble bee densities have been shown to be enhanced by a high proportion of mass-flowering crops in the landscape (Westphal, Steffan-Dewenter \& Tscharntke 2003). So far, cereal fields 
have not been considered as foraging habitats for bees, certainly because relatively few flowering plants occur in conventional fields. Our data confirmed that abundance and diversity of flowering plants in conventional wheat fields may be too low to provide resources for a large number of bee species. However, organic farming of wheat fields may considerably contribute to agricultural landscapes viable for a greater number of bee species, provided that sufficient seminatural areas for nesting are available (SteffanDewenter et al. 2002, Kremen et al. 2004). The $\beta$-diversity, which describes the species turnover among landscapes and regions, tracked the patterns found for the $\alpha$-diversity in organic and conventional fields (data not shown). This suggests that organic farming greatly contributes also to overall diversity at larger scales.

Flower cover and diversity of flowering plants may both have contributed to the observed pattern of bee diversity. Bee diversity often benefits from a high diversity of flowering plants, whereas abundance is correlated with flower cover (Steffan-Dewenter \& Tscharntke 2001). In our study, bee diversity depended on diversity of flowering plants in conventional fields, but not in organic fields. Instead, bee diversity was related to flower cover in organic fields. The absence of a relationship between bee and plant diversity in organic fields may have been caused by the generally high diversity of flowering plants in organic fields. Provided that a threshold of plant diversity is exceeded, bee species adapted to crop dominated environments may be enhanced by high flower cover instead. This is supported by the fact that all recorded bee species were classified as polylectic (Westrich 1989). We can not rule out that bee diversity in conventional fields was also influenced by flower cover, because diversity and cover of flowering plants were correlated in conventional fields.

\section{Effects of landscape context on plant and bee diversity}

Landscape context influenced bee diversity in organic and conventional fields differently resulting in larger differences between farming systems in homogeneous than in heterogeneous landscapes. We found the same pattern for flower cover and diversity of flowering plants suggesting that the effects of the landscape context on flowering plants were relayed to the pollinators. Similar results for relationships between landscape context and plant diversity were showed by Weibull, Östman \& 
Granquist (2003) and Roschewitz et al. (2005) with negative effects of landscape homogeneity generally more pronounced in conventional than in organic fields. Plant diversity in conventional fields probably suffers from a reduced area and smaller variety of permanent refuges for weed populations in homogeneous landscapes, whereas plant diversity in organic fields is self-sustaining to a certain extent (Roschewitz et al. 2005). The flower cover in organically managed fields was higher in homogeneous landscapes, whereas the cover in conventionally fields remained constantly low. The high flower cover in organic fields in homogeneous landscapes resulted from three major weed species (Matricaria chamomilla, Tripleurospermum inodorum and Sinapis arvensis). These species rank among the most abundant and economically important weeds in German winter cereals (Hanf 1990). M. chamomilla and T. inodorum have spread in the last decades, because chemical and mechanical control of these weeds proved to be difficult (Arlt 1991, Hinz \& McClay 2000). A possible reason for the benefit of $M$. chamomilla, T. inodorum and S. arvensis from homogeneous landscapes with a high proportion of crop fields may be that these weeds mainly occur on cultivated land. Perennial or ruderal sites contribute little to their overall population size (Fogg 1950, Kay 1994). Thus, seed rain of these weeds can be expected to be higher in homogeneous landscapes.

\section{Non-plant-mediated effect of the landscape context on bee diversity}

In addition to the variance of bee diversity explained by the cover and diversity of flowering plants, landscape context contributed to explain bee diversity after removing variance explained by flower resources in the statistical models. This non-plantmediated effect of landscape context resulted in higher bee diversity in heterogeneous landscapes. Presumably, study fields in homogenous landscapes have been more isolated from seminatural nesting habitats. Compared with other studies that found strong positive effects of heterogeneous landscape on local arthropod diversity (Weibull et al. 2000, Steffan-Dewenter et al. 2002, Clough et al. 2005) effects in this study were 
only marginal. This might be due to a lack of landscapes with extremely high or low proportions of seminatural habitats and the absence of more specialised bee species which depend on certain nesting sites and foraging plants (Banaszak 1992, Westrich 1996).

\section{Regional differences}

Bee diversity was significantly influenced by regional differences. The selected regions differed in a variety of aspects, e.g. regional species pool, large scale patterns of landuse, climatic and soil conditions. Our study design did not enable us to identify the factors causing regional differences in bee diversity. The motivation for addressing bee diversity in more than one region was to identify possible interactions between region and the other factors under investigation. The positive effect of organic farming and its modifications by the landscape context were robust across different regions suggesting that our results provide a reliable basis for management decisions. Regions were situated in different federal states of Germany. This is remarkable, because the governments of the German federal states play a significant role in the selection and development of agri-environment schemes. Directives of the EU are interpreted by the federal states, and programmes and subsidies depend on regions. Thus, the effectiveness of agri-environment schemes may not be evaluated at a national scale, but a regional perspective is needed (Wilson 1994).

\section{Conclusions}

Farming system, landscape context and regional context were involved in determining bee diversity. Organic wheat fields proved to be valuable foraging habitats providing diverse and abundant flower resources for a variety of bee species. The effectiveness of organic farming was largest in homogeneous landscapes. This interaction between farming system and landscape context clearly shows that evaluations of agrienvironment schemes have to incorporate a landscape perspective. Agri-environment schemes should aim to sustain heterogeneous landscapes because of their non-plantmediated positive effects on bee diversity. In homogeneous landscapes, organic farming greatly compensates for negative effects of landscape simplification. Thus, incentives 
for the conversion to organic farming or the retaining of non-intensive farming practices should show highest effectiveness in such intensively used landscapes. Benefits provided by organic farming may be even enhanced if agri-environment schemes explicitly promoted flowering plants by restricting mechanical weeding. From a conservation perspective organic farming may not benefit the specialised and threatened bee species occurring mainly in seminatural habitats but it helps to sustain diversity of bees and pollination services in agroecosystems.

Acknowledgments: We thank the farmers for their willingness to participate in the project, Stéphanie Domptail and Doreen Gabriel for their help with the land-use data, Tobias Purtauf for his participation in the selection of the study sites and Yann Clough for statistical advice and many helpful suggestions. This research was carried out within the framework of the EU-funded project 'EASY' (QLK5-CT- 2002-01495).

\section{References}

Arlt, K., Hilbig, W. \& Illig, H. (1991) Ackerunkräuter - Ackerwildkräuter. Zimsen Verlag, Wittenberg Lutherstadt.

Banaszak, J. (1992) Strategy for conservation of wild bees in an agricultural landscape. Agriculture, Ecosystems and Environment, 40, 179-192.

Bengtsson, J., Ahnström, J. \& Weibull, A.-C. (2005) The effects of organic agriculture on biodiversity and abundance: a meta-analysis. Journal of Applied Ecology, 42, 261-269.

Benton, T.G., Vickery, J.A. \& Wilson, J.D. (2003) Farmland biodiversity: is habitat heterogeneity the key? Trends in Ecology and Evolution, 18, 182-188.

Clough Y., Kruess A., Kleijn D. \& Tscharntke T. (2005) Spider diversity in cereal fields: comparing factors at local, landscape and regional scales. Journal of Biogeography, 32, 2007-2014.

Colwell, R.K. (2005) EstimateS: Statistical estimation of species richness and shared species from samples. Version 7.5. User's Guide and application published at: http://purl.oclc.org/estimates.

Corbet, S.A., Williams, I.H. \& Osborne J.L. (1991) Bees and the pollination of crops and wild flowers in the European Community. Bee World, 72, 47-59.

Fogg, G.E. (1950) Sinapis arvensis L.. Journal of Ecology, 38, 415-429. 
Gathmann, A. \& Tscharntke, T. (2002) Foraging ranges of solitary bees. Journal of Animal Ecology, 71, $757-764$

Hald, A.B. (1999) Weed vegetation (wild flora) of long established organic versus conventional cereal fields in Denmark. Annals of Applied Biology, 134, 307-314.

Hanf, M. (1990) Farbatlas Feldflora: Wildkräuter und Unkräuter. Ulmer, Stuttgart.

Hinz, H.L. \& McClay, A. (2000) Ten years of scentless chamomile: prospects for the biological control of a weed of cultivated land. Proceedings of the X International Symposium on Biological control of Weeds - July 4-14, 1999 (ed Neal R. Spencer), pp. 537-550, Montana State University, Bozeman, Montana.

Hole, D.G., Perkins, A.J., Wilson, J.D., Alexander, I.H., Grice, P.V. \& Evans, A.D. (2005) Does organic farming benefit biodiversity? Biological Conservation, 122, 113-130.

Hyvönen, T., Ketoja, E., Salonen, J., Jalli, H. \& Tiainen, J. (2003) Weed species diversity and community composition in organic and conventional cropping of spring cereals. Agriculture, Ecosystems and Environment, 97, 131-149.

Jonsen, I.D. \& Fahrig, L. (1997) Response of generalist and specialist insect herbivores to landscape spatial structure. Landscape ecology, 12, 185-197.

Kay, Q.O.N. (1994) Tripleurospermum inodorum (L.) Schultz Bip. Journal of Ecology, 82, 681-697.

Kleijn, D. \& Sutherland, W.J. (2003) How effective are European agri-environment schemes in conserving and promoting biodiversity? Journal of Applied Ecology, 40, 947-969.

Krebs, J.R., Wilson, J.D., Bradbury, R.B. \& Siriwardena, G.M. (1999) The second Silent Spring. Nature, 400, 611-612.

Kremen, C., Williams, N.M., Bugg, R.L., Fay, J.P. \& Thorp, R.W. (2004) The area requirements of an ecosystem service: crop pollination by native bee communities in California. Ecology Letters, 7 , 1109-1119.

Kremen, C., Williams, N.M. \& Thorp, R.W. (2002) Crop pollination from native bees at risk from agricultural intensification. Proceedings of the National Academy of Sciences of the USA, 99, 16812-16816.

Pinheiro, J.B. \& Bates, D.M. (2000) Mixed-effects models in S and S-Plus. Springer, New York.

R Development Core Team (2004) R: A language and environment for statistical computing. Foundation for Statistical Computing, Vienna. 
Reganold, J.P., Glover, J.D. \& Andrews, P.K. (2001) Sustainability of three apple production systems. Nature, 410, 926-930.

Richards, A.J. (2001) Does low biodiversity resulting from modern agricultural practice affect crop pollination and yield? Annals of Botany, 88, 165-172.

Roschewitz I., Gabriel D., Tscharntke T. \& Thies C. (2005) The effects of landscape complexity on arable weed species diversity in organic and conventional farming. Journal of Applied Ecology, 42, 873-882.

Schmidt, M.H., Roschewitz, I., Thies, C. \& Tscharntke, T. (2005) Differential effects of landscape and management on diversity and density of ground-dwelling farmland spiders. Journal of Applied Ecology, 42, 281-287.

Sokal, R.R. \& Rohlf, F.J. (1995) Biometry: the principles and practice of statistics in biological research. $3^{\text {rd }}$ edn. Freeman, New York.

Statistisches Bundesamt (2004) Landwirtschaft in Zahlen 2003, Wiesbaden. http://www.destatis.de/download/d/veroe/faltblatt/landw2003.pdf

Steffan-Dewenter, I., Münzenberg, U., Bürger, C., Thies, C. \& Tscharntke, T. (2002) Scale-dependent effects of landscape context on three pollinator guilds. Ecology, 83, 1421-1432.

Steffan-Dewenter, I. \& Tscharntke, T. (1999) Effects of habitat isolation on pollinator communities and seed set. Oecologia, 121, 432-440.

Steffan-Dewenter, I. \& Tscharntke, T. (2001) Succession of bee communities on fallows. Ecography, 24, 83-93.

Stoate, C., Boatman, N.D., Borralho, R.J., Carvalho, C.R., de Snoo, G.R. \& Eden, P. (2001) Ecological impacts of arable intensification in Europe. Journal of Environmental Management, 63, 337-365.

Thies, C. \& Tscharntke, T. (1999) Landscape structure and biological control in agroecosystems. Science, 285, 893-895.

Thompson, H.M. (2001) Assessing the exposure and toxicity of pesticides to bumblebees. Apidologie, 32 , 305-321.

Thompson, H.M. (2003) Behavioural effects of pesticides in bees - their potential for use in risk assessment. Ecotoxicology, 12, 317-330.

Tilman, D., Cassman, K.G., Matson, P.A., Naylor, R. \& Polasky, S. (2002) Agricultural sustainability and intensive production practices. Nature, 418, 671-677. 
Tilman, D., Fargione, J., Wolff, B., D'Antonio, C., Dobson, A., Howarth, R., Schindler, D., Schlesinger, W.H., Simberloff, D. \& Swackhamer, D. (2001) Forecasting agriculturally driven global environmental change. Science, 292, 281-284.

Tscharntke T., Klein A.M., Kruess A., Steffan-Dewenter I., Thies C. (2005) Landscape perspectives on agricultural intensification and biodiversity - ecosystem service management. Ecology Letters, 8, $857-874$

Tybirk, K., Alroe, H.F. \& Frederiksen, P. (2004) Nature quality in organic farming: a conceptual analysis of considerations and criteria in European context. Journal of Agriculture and Environmental Ethics, 17, 249-274.

Weibull, A.-C., Bengtsson, J. \& Nohlgren, E. (2000) Diversity of butterflies in the agricultural landscape: the role of farming system and landscape heterogeneity. Ecography, 23, 743-750.

Weibull, A.-C., Östman, Ö. \& Granquist, Å. (2003) Species richness in agroecosystems: the effect of landscape, habitat and farm management. Biodiversity and Conservation, 12, 1335-1355.

Westphal C., Steffan-Dewenter I. \& Tscharntke T. (2003) Mass flowering crops enhance pollinator densities at a landscape scale. Ecology Letters, 6, 961-965.

Westrich P. (1989) Die Wildbienen Baden-Württembergs - Spezieller Teil. Ulmer Verlag, Stuttgart.

Westrich, P. (1996) Habitat requirements of central European bees and the problems of partial habitats. The conservation of bees (ed. A. Matheson, S.L. Buchmann, C. O'Toole, P. Westrich \& I.H. Williams), pp. 1-16. Academic Press, London

Williams, I.H. (1996) Aspects of bee diversity and crop pollination in the European Union. The conservation of bees (ed. A. Matheson, S.L. Buchmann, C. O'Toole, P. Westrich \& I.H. Williams), pp. 63-80. Academic Press, London.

Wilson G.A. (1994) German agri-environmental schemes - I. A preliminary review. Journal of Rural Studies, 10, 27-45.

Wilson, J.D., Morris, A.J., Arroyo, B.E., Clark, S.C. \& Bradbury, R.B. (1999) A review of the abundance and diversity of invertebrates and plant foods of granivorous birds in northern Europe in relation to agricultural change. Agriculture, Ecosystems and Environment, 75, 13-30. 


\title{
Chapter 3
}

\section{Landscape-scale effects of crop-noncrop resource fluxes: organic farming enhances bee diversity in fallow strips}

\begin{abstract}
Spatial fluxes across habitats providing allochthonous resources from outside the habitat may have landscape-scale influences on community dynamics. This is particularly evident when movements of multi-habitat users connect habitat patches at a landscape scale and contribute to diversity levels not maintained by one habitat patch on its own. Traditionally, flower-visiting multi-habitat users have been expected to perceive cereal fields as hostile landscape matrix because they do not provide food resources and may even hamper movements between habitat patches. It has remained unexplored how the local farming intensity in crop fields influences the inhospitality of the matrix and diversity levels of multi-habitat users at a landscape scale.
\end{abstract}

In this study, we compared bee communities in fallow strips adjacent to organic and conventional wheat fields, surrounded by landscape sectors differing in the proportions of organic crop fields and seminatural habitats. We show that organic farming of crop fields influenced bees in fallow strips at a local and a landscape scale. At the local scale, species richness of bees and abundance of solitary and bumble bees were higher in fallow strips adjacent to organic than to conventional fields. Organic fields provided higher species richness and cover of flowering plants than conventional fields, but due to the annually ploughed soils, the mainly ground-nesting bees can only find 
nesting sites in perennial habitats such as the fallow strips. At the landscape scale, a high proportion of organic crop fields in the surrounding landscape enhanced total species richness of bees and abundances of solitary, bumble and honey bees. A high proportion of seminatural habitats in the landscape enhanced the abundance of solitary bees only.

Cross-habitat fluxes appeared to connect different habitats at a landscape scale, because bees in fallow strips benefited from the huge nectar and pollen resources provided by organic fields, but depended on the nesting sites provided by fallow strips. We conclude that spillovers promoted by organic farming of crop fields can be a determining factor in insect communities in noncrop habitats. Agri-environment schemes which aim to enhance biodiversity by low-intensity farming practices at the local field or farm scale may have landscape-wide implications for community structure and trophic interactions.

\section{Keywords}

Agri-environment schemes, bumble bees, conservation, honey bees, field margins, pollinators, seminatural habitats, solitary bees, spatial scale, spillover effects 


\section{Introduction}

Processes occurring at landscape scales have substantial influence on local diversity and dynamics (Kareiva \& Wennergren 1995, Polis et al. 1997, Bestelmeyer et al. 2003). Impacts of landscape factors can be even more important than the influence of local habitat characteristics (Kremen et al. 2002, 2004, Weibull et al. 2003). Especially multihabitat users which move among habitats during their lifetime couple dynamics of different habitats (Duelli et al. 1990). As a result of these cross-habitat fluxes, organisms in one habitat can be subsidised by resources in a second habitat. Thus, movements among habitats providing different resources might increase diversity in habitats that are too resource-poor to sustain populations on its own (Polis et al. 1997). Fluxes may occur between natural or seminatural habitats, between regularly disturbed anthropogenic habitats or across natural-anthropogenic habitat interfaces (Duelli et al. 1990, Rand et al. 2006).

Agroecosystems benefit from cross-habitat fluxes from remnant (semi-)natural habitats into crop habitats, since valuable ecosystem services such as biological control and pollination in crop fields are enhanced by less disturbed habitats in the surrounding landscape (Kremen et al. 2004, Schmidt \& Tscharntke 2005). Studies at a landscape scale showed that bee diversity and pollination services in crop fields were enhanced by natural habitats in the vicinity of farms more than by local non-intensive organic farm management (Kremen et al. 2002, 2004). The reverse effect - crop habitats enhance organisms in noncrop habitats - has been documented only rarely (Tscharntke et al. 2005). Effects of agricultural habitats on natural habitats may often result from concentration of organisms in permanent habitats after crop harvest (Saunders et al. 1991, Thorbek \& Bilde 2004). In general, high-productive anthropogenic habitats may have the potential to subsidize populations in less productive natural or seminatural habitats (Polis et al. 1997). For example, high-productive mass flowering crops have been found to subsidize bumblebees in fallows at a landscape scale (Westphal et al. 2003). Documented positive effects of crop habitats on diversity and abundances in noncrop habitats are rare, and annual crop fields have been often considered as hostile landscape matrix. However, anecdotal evidence suggest that increasing predator and herbivore densities in productive crop fields might result in spillover effects which also 
enhance population densities in adjacent natural habitats (Rand et al. 2005, Tscharntke et al. 2005).

Fallow strips and seminatural habitats are traditionally considered as permanent refuges and sources of bees, because bees are not able to nest in annually ploughed crop fields (Lagerlöf et al. 1992, Bäckmann \& Tiainen 2002, Meek et al. 2002, Steffan-Dewenter et al. 2002, Carvell et al. 2004, Pywell et al. 2005, Pywell et al. 2006). In this study, we tested whether food subsidies arising from organic farming of annual crop fields enhance bee diversity in fallow strips at a local and a landscape scale. We hypothesized (1) that bee species richness and abundance are higher in fallow strips adjacent to organic than to conventional fields (local scale) and (2) that bee species richness and abundance increase with the proportion of organic crop fields in the landscape (landscape scale).

\section{Methods}

\section{Study regions and study sites}

In 2003, bees were monitored in 42 permanent field fallow strips in three regions in Germany (Soester Börde/North Rhine-Westphalia, Leine Bergland/Lower-Saxony and Lahn-Dill-Bergland/Hesse, 14 fallow strips per region). The regions were situated about $150 \mathrm{~km}$ from each other, and between 400 and $500 \mathrm{~km}^{2}$ in size. 21 fallow strips were adjacent to organic winter wheat fields and 21 adjacent to conventional winter wheat fields. Organic fields were managed according to the European Union regulation 2092/91/EEC. This regulation limits the amount of fertilizers and prohibits among others the use of synthetic fertilisers and pesticides. Each fallow strip adjacent to an organic field was paired with the first nearby fallow strip adjacent to a conventional winter wheat field. These pairs allowed a comparison of fallow strips adjacent to fields differing in the farming system (organic vs. conventional), but similar in abiotic conditions and landscape context. Distances between fallow strips within a pair ranged from $0 \mathrm{~m}$ to $600 \mathrm{~m}$ and between pairs within a region from $3 \mathrm{~km}$ to $45 \mathrm{~km}$. All fallow strips were established between the wheat field and a farm track, had a naturally developed herb and grass layer, and mostly included a narrow ditch. The occurrence of 
a ditch and the management of fallow strips (mowing once a year) did not differ between the two farming types. Mean fallow strip width was $2.6 \pm 1.4 \mathrm{~m}$ (SE) and did not differ in fallow strips adjacent to conventional or organic fields (t-test for paired samples: $\mathrm{t}=1.34, \mathrm{P}=0.196)$. Species richness of flowering plants and flower cover were significantly higher in organic than in conventional fields ( $\mathrm{t}$-test for paired samples: species richness: $\mathrm{t}=9.39, \mathrm{P}<0.001$ mean $_{\text {conv }}=5.4$, mean $_{\text {org }}=12.6$; flower cover: $\mathrm{t}=3.91, \mathrm{P}<0.001, \operatorname{mean}_{\mathrm{conv}}=0.1 \%$ mean $\left._{\text {org }}=2.9 \%\right)$ and in fallow strips adjacent to organic higher than adjacent to conventional fields (species richness: $\mathrm{t}=2.29, \mathrm{P}=0.033$, mean $_{\text {conv }}=12.4$, mean $_{\text {org }}=16.9$; flower cover: $\mathrm{t}=2.82, \mathrm{P}=0.011$, mean $_{\text {conv }}=1.2 \%$, mean $_{\text {org }}=3.3 \%$ ), presumably due to plant spillover from the adjacent field or the absence of agrochemical drift in organic fallow strips.

\section{Quantifying landscape context}

For each fallow strip, the surrounding landscape was characterised in a circular landscape sector (radius $1000 \mathrm{~m}$ ). Field inspections were made to record the areas of different habitat types in these landscape sectors on the base of official topographical maps (DGK 1:5000). Crop fields were identified as organically managed by interviewing the organic farmers. To study scale-dependent effects of landscape factors each of the 42 circular landscape sectors was subdivided into four nested sectors (radii: $250 \mathrm{~m}, 500 \mathrm{~m}, 750 \mathrm{~m}, 1000 \mathrm{~m})$. We calculated the proportion of organic crop fields and the proportion of seminatural habitats in each landscape sector individually for the four spatial scales using Geographic Information Systems (GIS; Topol 4.506, Gesellschaft für digitale Erdbeobachtung und Geoinformation $\mathrm{mbH}$, Göttingen, Germany and ARC/View 3.2., ESRI Geoinformatik GmbH, Hannover, Germany). We classified fallows and ruderal areas, allotment gardens, vegetation along inshore waters, calcareous grasslands, orchard meadows, hedgerows and forest edges $(10 \mathrm{~m}$ deep boundary) as seminatural habitats. The proportion of organically managed crop fields did not differ between regions at all spatial scales, as well as the proportion of seminatural habitats at scales up to $500 \mathrm{~m}$ (linear mixed-effects models, $\mathrm{P}>0.1$ ). The studied landscapes were made up of a patchwork of grasslands, seminatural habitats, forests and crop fields. Organic and conventional fields of different farmers were 
interspersed. The proportion of organic crop fields in the landscape varied between 0.4 $\%$ and $33.8 \%$ (mean \pm SE: $10.7 \pm 8.4 \%, 500$ m radius). All landscapes were farmland dominated, so the gradient of seminatural habitats was rather small varying between 0.6 $\%$ and $15.5 \%(7.1 \pm 4.1 \%, 500 \mathrm{~m}$ radius $)$.

We used Spearman rank correlations to test for correlations between landscape parameters. Correlation analyses were separately conducted for landscape sectors around fallow strips adjacent to organic and adjacent to conventional fields. The proportion of seminatural habitats was positively correlated with the Shannon-index of habitat diversity and negatively with the proportion of total crop fields only at the $250 \mathrm{~m}$ radius. There were no correlations with proportions of other habitat types (organic crop fields, grassland, forest) or with elevation at any spatial scale. The proportion of organic crop fields in the landscape was highly correlated at all spatial scales with the area of organic crop fields per total area of crop fields (= proportion of total crop fields which was managed organically: min - max: $0.6-46.1 \%$, mean $\pm \mathrm{SE}: 16.1 \pm 12.0 \%$ ). The proportion of organic crop fields was not correlated to other landscape parameters or elevation at any spatial scale, indicating that the uptake of organic farming by farmers did not depend on landscape context at these scales.

\section{Bee surveys}

We caught all visible bees (Apiformes) with sweep nets in four surveys between May and July for 15 min along a 95-m-transect per fallow strip. Fallow strips were fully sampled along these transects. We surveyed fallow strips of a organic-conventional-pair directly one after the other, between 10:00 and 18:00, only at low wind speeds, at least $18^{\circ} \mathrm{C}$ and at least $70 \%$ sun. Bees were brought to the laboratory for identification. The species richness of bees is the total number of bee species caught within the study period. Bee abundances were calculated as numbers of individuals caught within 4 x 15 min per $100 \mathrm{~m}^{2}$ fallow strip. Solitary bees, bumble bees and honey bees were expected to respond differently to the landscape context, because they differ in their habitat and food requirements. Therefore, bee abundances were calculated separately for these three pollinator groups (Steffan-Dewenter et al. 2002). 


\section{Statistics}

In linear mixed-effects models (Pinheiro \& Bates 2000), we separately tested the effects of both landscape parameters - proportion of organic crop fields and proportion of seminatural habitats - on species richness and abundance of bees. Fallow strips adjacent to neighbouring organic and conventional fields were grouped by adding block as random factor. Since landscape sectors of fallow strips within an organic-conventionalpair were not independent, the landscape parameters were tested on the level of pairs. The four spatial scales per landscape sector were analysed separately. For all models, the F-values of the tested landscape parameters were plotted to demonstrate the influence of the spatial scale on the correlation between landscape parameters and species richness and abundances of bees, respectively (Steffan-Dewenter et al. 2002, Kremen et al. 2004). In the further analysis, we tested landscape effects on species richness and abundances of bees at that spatial scale, where correlations (i.e. F-values) were strongest. By using linear-mixed effect models, we analysed effects jointly at the local scale (farming system of the adjacent field: organic vs. conventional) and at the landscape scale (proportion of organic crop fields, proportion of seminatural habitats) on species richness and abundances of bees. Effects of region and fallow strip width were tested in the full model, but had no additional explanatory power. Independent variables which did not contribute to the model with $\mathrm{P}<0.05$ were removed in a stepwise backward procedure from the full model. The bee species richness and the abundances of the three pollinator groups were transformed $(\log 10(x+1))$. All statistical analyses were performed using R (R Development Core Team 2004).

\section{Results}

In total, 1612 bee individuals were caught (302 solitary bees, 932 bumble bees, 378 honey bees). We identified 40 bee species from thirteen genera. The most species-rich genera were Andrena (17 species), Bombus (7 species), Nomada (4 species) and Lasioglossum ( 3 species). We found 16 species exclusively in fallow strips adjacent to organic fields, and 3 species exclusively in fallow strips adjacent to conventional fields. 
The proportion of organic crop fields in the landscape influenced the bee species richness and abundances of solitary bees, bumble bees and honey bees (Fig. 1). The plotted F-values revealed that the effect of organic crop fields in the landscape had its maximum at $500 \mathrm{~m}$ radius around the study sites for the bee species richness and the abundances of bumble bees and honey bees (Fig. $1 \mathrm{a}, \mathrm{c}, \mathrm{d}$ ). The abundance of solitary bees responded strongest to landscape factors in $250 \mathrm{~m}$ radius around the study sites (Fig. 1b). Both the proportion of organic crop fields and the proportion of seminatural habitats showed a significant effect on solitary bees.

a) Number of bee species

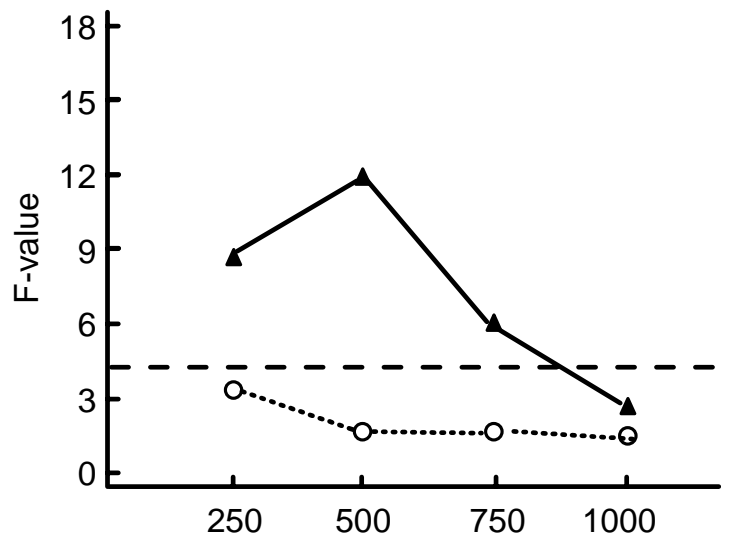

c) Number of bumble bees

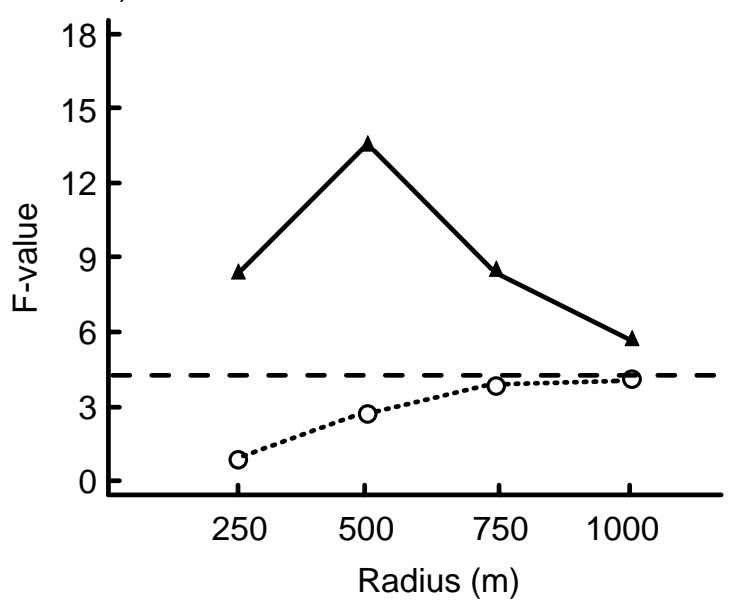

b) Number of solitary bees

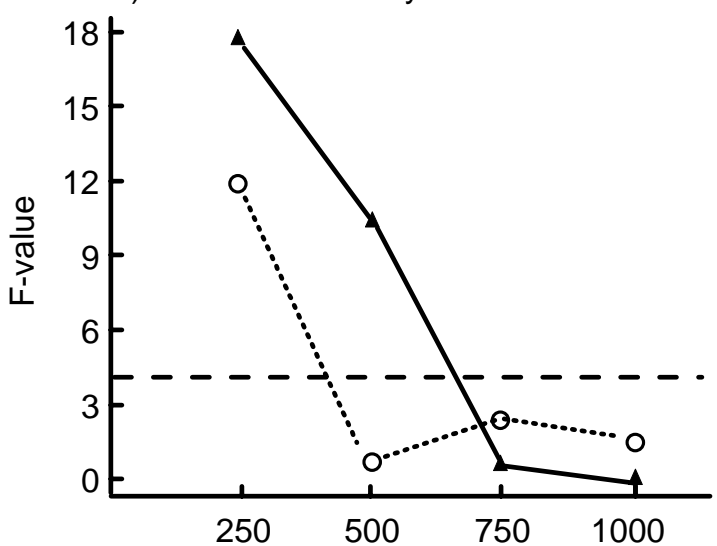

d) Number of honey bees

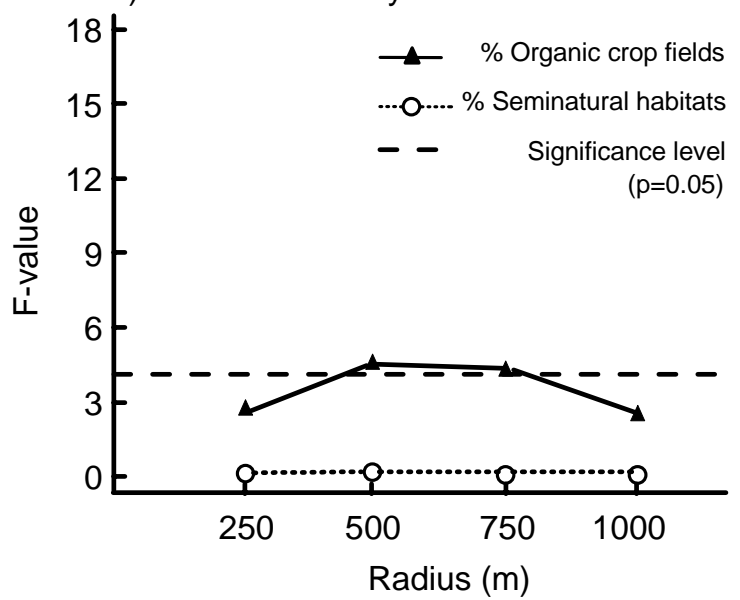

Fig. 1 Effects of the proportion of organic crop fields and the proportion of seminatural habitats on bee species richness and the abundance of solitary bees, bumble bees and honey bees in fallow strips. Fvalues are from linear mixed-effects models with proportion of organic fields and proportion of seminatural habitats separately for the four landscape sectors with $250-1000 \mathrm{~m}$ radius. The dashed line shows the critical $F_{1,21}$-value for the significance level $\mathrm{P}=0.05$. 
In a further analysis, we jointly tested the effects of the two landscape parameters and the farming system of the adjacent field (organic vs. conventional) on bees. We used landscape parameters calculated for landscape sectors with 500 m radius in the analyses of the species richness of bees and the abundances of bumble bees and honey bees, and with $250 \mathrm{~m}$ radius in the analysis of the abundance of solitary bees. Species richness of bees and the abundances of solitary bees and bumble bees, but not of honey bees, were higher in fallow strips adjacent to organic than in fallow strips adjacent to conventional fields (Table 1, Fig. 2 A). A high proportion of organic fields in the landscape enhanced the species richness of bees and the abundances of solitary bees, bumble bees and honey bees (Table 1). Seminatural habitats increased the abundance of solitary bees only (Table 1). The positive impact of a high proportion of organic fields in the landscape influenced species richness of bees in both organic and conventional fallow strips similarly (Fig. 2 B).

Table 1: Final linear mixed-effects models describing the effects of the farming system practiced in the adjacent wheat field (organic vs. conventional) and of the proportions of organic crop fields and seminatural habitats in the landscape sectors (scales selected by the comparison of F-values from linear mixed-effects models with one landscape factor at a time, see Fig. 1).

\begin{tabular}{lccc}
\hline \hline & DF & F & P \\
\hline $\begin{array}{l}\text { Bee species richness } \\
\text { Farming system }\end{array}$ & 20 & 6.48 & 0.019 \\
\% Organic crop fields $(500 \mathrm{~m})$ & 20 & 6.48 & 0.019 \\
Abundance of solitary bees & & & \\
$\quad$ Farming system & 19 & 12.18 & 0.002 \\
\% Organic crop fields $(250 \mathrm{~m})$ & 19 & 7.21 & 0.015 \\
\% Seminatural habitats $(250 \mathrm{~m})$ & 19 & 5.05 & 0.037 \\
$\begin{array}{l}\text { Abundance of bumble bees } \\
\text { Farming system }\end{array}$ & & & \\
\% Organic crop fields $(500 \mathrm{~m})$ & 20 & 7.87 & 0.011 \\
Abundance of honey bees & 20 & 8.72 & 0.008 \\
\% Organic crop fields $(500 \mathrm{~m})$ & & & \\
\hline
\end{tabular}



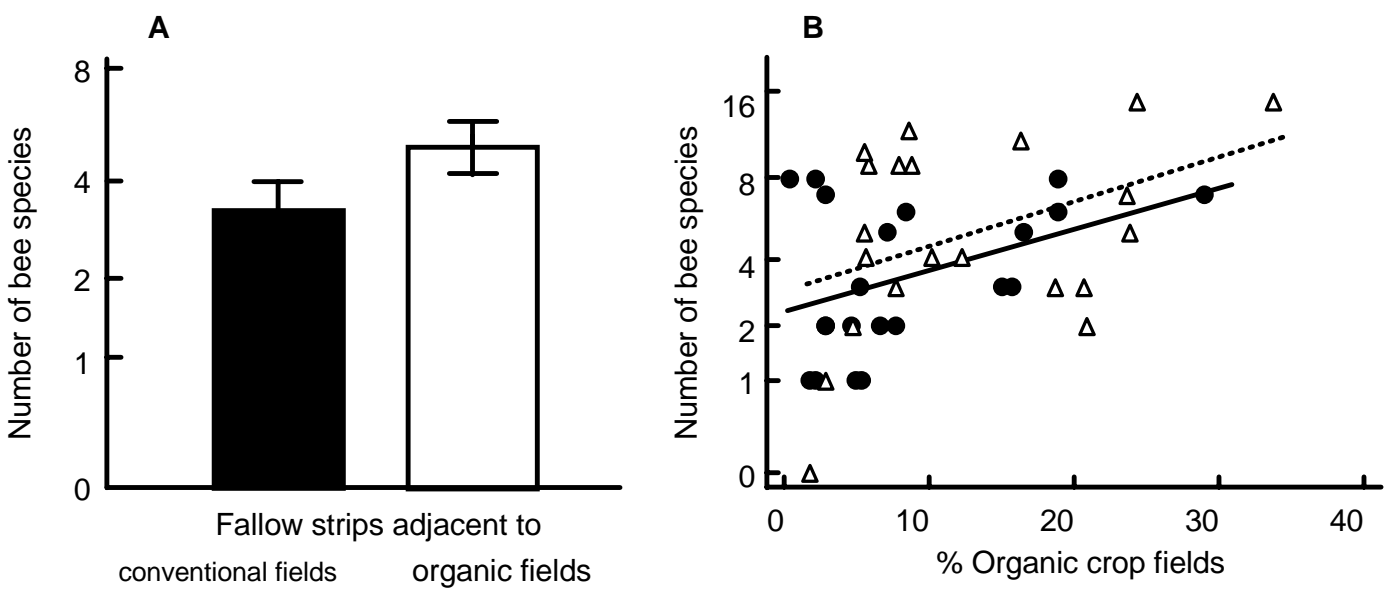

Fig. 2 (A) Effect of the farming system (organic vs. conventional) of the adjacent wheat field on bee species richness in 42 fallow strips. Means and standard errors are given. (B) Landscape effect of the proportion of organic crop fields in landscape sectors with $500 \mathrm{~m}$ radius on the species richness of bees in 42 fallow strips adjacent to organic wheat fields (triangles and dashed line) and conventional wheat fields (points and solid line). Results are from mixed-effects models (see Table 1).

\section{Discussion}

Our results support the hypotheses that species richness of bees and abundances of solitary and bumble bees in fallow strips benefit from organic farming in the adjacent field (local scale) and from a high proportion of organic fields in the landscape (landscape scale). Hence, crop-noncrop resource fluxes appeared to influence bee communities at local and landscape scales.

\section{Local scale}

Species richness of bees and abundances of solitary and bumble bees were higher in fallow strips adjacent to organic than in fallow strips adjacent to conventional wheat fields. Differences in the bee fauna in organic and conventional fallow strips were caused by differences in the farming systems of the adjacent fields, because fallow strips themselves did not differ in their management (mowing once a year). Organic and conventional fields mainly differ due to the absence of agrochemicals in organic fields resulting in a higher density and species richness of the noncrop vegetation in organic than in conventional fields (Hald 1999, Hyvönen et al. 2003, Bengtsson et al. 2005). Roschewitz et al. (2005) found $11 \%$ field cover of broad-leaves and a mean diversity of 
50 weed species in organic wheat fields, which are similar to the fields in our study, compared with $1 \%$ field cover of broad-leaves and 27 weed species in conventional wheat fields. The high density and diversity of nectar and pollen resources can be expected to enhance bees in organic fields (Banaszak 1992). Bees in fallow strips may be influenced by the farming system of the adjacent field in two ways. First, resource use in the adjacent field may result in higher abundance and species richness in fallow strips adjacent to organic than to conventional fields. Second, the absence of agrochemical drift in fallow strips adjacent to organic fields may enhance the flower availability (de Snoo \& van der Poll 1999, Marshall \& Moonen 2002, Aude et al. 2003).

\section{Landscape scale}

Beside the positive effect of organic farming at the local scale, a high proportion of organic crop fields in the surrounding landscape enhanced species richness of bees and abundances of solitary, bumble and honey bees in fallow strips. A high proportion of seminatural habitats enhanced the abundance of solitary bees only, supporting studies showing positive effects of (semi-)natural habitats on the species richness of wild bees in agricultural landscapes (Kremen et al. 2002, Steffan-Dewenter et al. 2002). (Semi-) natural habitats provide diverse flower resources and, in contrast to annually ploughed fields, nesting sites for wild bees (Baszanak 1992, Westrich 1996). Thus, (semi-)natural habitats have been considered as the source of bee species richness.

Bees are multi-habitat users, and cross-habitat fluxes of resources and pollinators connect different seminatural habitats (Westrich 1996). In addition, cross-habitat fluxes exist between (semi-)natural reproduction habitats and mass-flowering crop fields (Kremen et al. 2002). Inversely, bumble bees foraging in flowering crops can contribute to increased densities of bumble bees at a landscape scale (Westphal et al. 2003). Nonflowering crops such as cereals, which took the largest part of arable land (Statistisches Bundesamt 2004), have been considered as landscape matrix without value for pollinators or as even hostile, because they isolate remaining habitat fragments from each other (Westrich 1996). Our results provide the first evidence that annual crop fields are not hostile and may enhance species richness of species groups that depend on perennial habitats for reproduction. Up to now, positive effects provided by organic 
farming have been considered only at field scales and in relation to conventional farming practices (reviewed in Bengtsson et al. 2005, Hole et al. 2005). Impacts of organic farming on habitats other than the directly non-intensively managed fields remained unexplored. According to our data, the local benefits provided by organic farming were large enough to cause spillover effects which determine species richness of bees in fallow strips at a local and landscape scale.

Generally, spillover effects arise when resources in a productive habitat locally enhance diversity or abundance which subsequently subsidize communities in other habitats (Polis et al. 1997), but are almost unknown from human-dominated landscapes (Rand et al. 2006). In landscapes with high proportions of organic fields and therefore high cover of flowering plants, pollen and nectar resources spillover enhanced bee communities in fallow strips (independent of whether there were adjacent to organic or conventional fields). Given that fallow strips adjacent to organic fields were more valuable for pollinators than fallow strips adjacent to conventional fields they may have the potential to subsidize bees at the landscape scale. However, we assume that spillovers from flower-rich organic fields were more important for the enhancement of pollinators at the landscape scale, because cover of flowering plants in organic wheat fields were as high as in fallow strips adjacent to organic fields (A. Holzschuh, unpubl. data) and the area of fallow strips was negligible compared with the area of organic fields.

The occurrence of bee species recorded in the fallow strips was apparently limited by foraging resources mainly provided in organic fields and nesting sites. Bumble bees are known to be less restricted by seminatural habitat providing nesting sites (Westphal et al. 2003), because the dominant species can nest in the fallow strips themselves (Svensson et al. 2000). Solitary bees were the only bee group benefiting from both organic fields and seminatural habitats in the landscape. Our results corroborate the conclusions drawn in other studies that solitary bees are more restricted by their nesting requirements than bumble bees and perceive their landscape at smaller spatial scales due to their smaller foraging distances (Gathmann \& Tscharntke 2002, SteffanDewenter et al. 2002). 
Honey bees generally show weak responses to the proportion of foraging habitats in the landscape (Steffan-Dewenter et al. 2002). They depend on other factors such as the location of apiaries (Steffan-Dewenter \& Tscharntke 2000) and exploit only few but high quality food patches within their range (Visscher \& Seeley 1982). We only found generalist solitary and bumble bees in the study fallow strips. Thus, fallow strips and high proportions of organic fields were obviously not able to compensate for missing seminatural habitats sustaining specialist species. Other measures than low-intensity farming systems are required for the conservation of specialist bees in agricultural landscapes.

According to our models, an increase of the proportion of organic crop fields from now $4.4 \%$ to $20 \%$ as the German government aims to achieve by 2010 may enhance species richness of bees in fallow strips by $54 \%$, density of solitary bees by $66 \%$ and bumble bee density by $156 \%$. Our results suggest that assessing impacts of agri-environment schemes needs a landscape perspective that not only takes landscape complexity into account, but which also include potential effects of the schemes at a landscape scale. Further, a landscape perspective provide an insight in the spatial scales at which agrienvironment schemes work most effectively in enhancing biodiversity, and financial support of farmers should be linked to spatial arrangement of organic fields at the relevant landscape scale. Since bees perceive their environment at landscape scales, it is apparently not necessary to provide all requirements in close proximity. In return, pollination services can be expected to be enhanced within landscape sectors at these scales (Kremen 2005). As solitary bees respond to landscape factors within $250 \mathrm{~m}$ radius, populations in a distance of $>500 \mathrm{~m}$ from each other should be considered as non-overlapping service-providing units (sensu Luck et al. 2003). The absence of the requirements of such a service-providing unit may result in the loss of pollination service within this landscape sector and negatively affect wild plant species as well as insect-pollinated crops (Luck et al. 2003, Kremen et al. 2004). In conclusion, we showed practically important landscape-scale effects of crop-noncrop resource fluxes that need to be taken into account when designing conservation management plans in human-dominated landscapes. 
Acknowledgments: We thank the farmers for their participation in the project, Stéphanie Domptail and Doreen Gabriel for GIS-support, Tobias Purtauf for his help with the site selection, Yann Clough for statistical advice and Jochen Krauss for helpful suggestions. This research was carried out within the framework of the EU-funded project 'EASY' (QLK5-CT-2002-01495) coordinated by David Kleijn.

\section{References}

Aude E., Tybirk K., Michelsen A., Ejrnaes R., Hald A.B. \& Mark S. (2004) Conservation value of the herbaceous vegetation in hedgerows - does organic farming make a difference? Biol. Conserv., 118, 467-478.

Bäckmann J.-P.C. \& Tiainen J. (2002) Habitat quality of field fallows in a Finnish farmland area for bumblebees (Hymenoptera: Bombus and Psithyrus). Agr. Ecosyst. Environ., 89, 53-68.

Banaszak J. (1992) Strategy for conservation of wild bees in an agricultural landscape. Agr. Ecosyst. Environ., 40, 179-192.

Bengtsson J., Ahnström J. \& Weibull A.-C. (2005) The effects of organic agriculture on biodiversity and abundance: a meta-analysis. J. Appl. Ecol., 42, 261-269.

Benton T.G., Vickery J.A. \& Wilson J.D. (2003) Farmland biodiversity: is habitat heterogeneity the key? Trends Ecol. Evol., 18, 182-188.

Bestelmeyer B.T., Miller J.R. \& Wiens J.A. (2003) Applying species diversity theory to land management. Ecol. Appl.,13, 1750-1761.

Carvell C., Meek W.R., Pywell R.F. \& Nowakowski M. (2004) The response of foraging bumblebees to successional change in newly created arable field fallows. Biol. Conserv., 118, 327-339.

de Snoo G.R. \& van der Poll R.J. (1999) Effect of herbicide drift on adjacent boundary vegetation. Agr. Ecosyst. Environ., 73, 1-6.

Duelli P., Studer M., Marchand I. \& Jakob S. (1990) Population-movements of arthropods between natural and cultivated areas. Biol. Conserv., 54, 193-207. 
Fahrig L. (2003) Effects of habitat fragmentation on biodiversity. Annu. Rev. Ecol. Evol. S., 34, 487-515.

Firbank L.G. (2005) Striking a new balance between agricultural production and biodiversity. Ann. Appl. Biol., 164, 163-175.

Gathmann A. \& Tscharntke T. (2002) Foraging ranges of solitary bees. J. Anim. Ecol.,71, 757-764.

Hald A.B. (1999). Weed vegetation (wild flora) of long established organic versus conventional cereal fields in Denmark. Ann. Appl. Biol., 134, 307-314.

Hole D.G., Perkins A.J., Wilson J.D., Alexander I.H., Grice P.V. \& Evans A.D. (2005) Does organic farming benefit biodiversity? Biol. Conserv., 122, 113-130.

Hyvönen T., Ketoja E., Salonen J., Jalli H. \& Tiainen J. (2003) Weed species diversity and community composition in organic and conventional cropping of spring cereals. Agr. Ecosyst. Environ., 97, $131-149$

Kareiva P. \& Wennergren U. (1995) Connecting landscape patterns to ecosystems and population processes. Nature, 373, 299-302.

Krebs J.R., Wilson J.D., Bradbury R.B. \& Siriwardena G.M. (1999) The second silent spring. Nature, 400, 611-612.

Kremen C. (2005) Managing ecosystem services: what do we need to know about their ecology. Ecol. Lett., 8, 468-479.

Kremen C., Williams N.M., Bugg R.L., Fay J.P. \& Thorp R.W. (2004) The area requirements of an ecosystem service: crop pollination by native bee communities in California. Ecol. Lett., 7, 1109-1119.

Kremen C., Williams N.M. \& Thorp R.W. (2002) Crop pollination from native bees at risk from agricultural intensification. Proc. Nat. Acad. Sci. USA, 99, 16812-16816.

Lagerlöf J., Stark J. \& Svensson B. (1992) Fallows of agricultural fields as habitats for pollinating insects. Agr. Ecosyst. Environ., 40, 117-124.

Luck G.W., Daily G.C. \& Ehrlich P.R. (2003) Population diversity and ecosystems services. Trends Ecol. Evol., 18, 331-336.

Marshall E.J.P. \& Moonen A.C. (2002) Field fallows in northern Europe: their functions and interactions with agriculture. Agr. Ecosyst. Environ., 89, 5-21. 
Meek B., Loxton D., Sparks T., Pywell R., Pickett H. \& Nowakowski M. (2002) The effect of arable field fallow composition on invertebrate biodiversity. Biol. Conserv., 106, 259-271.

Pinheiro J.B. \& Bates D.M. (2000) Mixed-effects models in S and S-Plus. Springer, New York.

Polis G.A., Anderson W.B. \& Holt R.D. (1997) Toward an integration of landscape and food web ecology: the dynamics of spatially subsidized food webs. Annu. Rev. Ecol. Syst., 28, 289-316.

Pywell R.F., Warman E.A., Carvell C., Sparks T.H., Dicks L.V., Bennett D., Wright A., Critchley C.N.R. \& Sherwood A. (2005) Providing foraging resources for bumblebees in intensively farmed landscapes. Biol. Conserv., 121, 479-494.

Pywell R.F., Warman E.A., Hulmes L., Hulmes S., Nuttall P., Sparks T.H., Critchley C.N.R., Sherwood A. (2006) Effectiveness of new agri-environment schemes in providing foraging resources for bumblebees in intensively farmed landscapes. Biol. Conserv., 129, 192-206.

R Development Core Team (2004) R: A language and environment for statistical computing. Foundation for Statistical Computing, Vienna.

Rand T. A., Tylianakis J.M., Tscharntke T. (2006) Spillover edge effects: the dispersal of agriculturallysubsidized insect natural enemies into adjacent natural habitats. Ecol. Lett. (in press).

Roschewitz I., Gabriel D., Thies, C. \& Tscharntke, T. (2005) Contrasting effects of landscape complexity on arable weed diversity in organic and conventional farming. J. Appl. Ecol., 42, 873-882.

Saunders D.A., Hobbs R.J. \& Margules C.R. (1991) Biological consequences of ecosystem fragmentation - a review. Conserv. Biol., 5, 18-32.

Schmidt M.H. \& Tscharntke T. (2005) Landscape context of sheetweb spider (Araneae: Linyphiidae) abundance in cereal fields. J. Biogeogr., 32, 467-473.

Statistisches Bundesamt (2004) Landwirtschaft in Zahlen 2003, Wiesbaden. http://www.destatis.de/download/d/veroe/faltblatt/landw2003.pdf

Steffan-Dewenter I. \& Kuhn A. (2003) Honeybee foraging in differentially structured landscapes. P. Roy. Soc. Lond. Ser. B, 270, 569-575.

Steffan-Dewenter I., Münzenberg U., Bürger C., Thies C. \& Tscharntke T. (2002) Scale-dependent effects of landscape context on three pollinator guilds. Ecology, 83, 1421-1432.

Steffan-Dewenter I. \& Tscharntke T. (1999) Effects of habitat isolation on pollinator communities and seed set. Oecologia, 121, 432-440. 
Steffan-Dewenter I. \& Tscharntke T. (2000) Resource overlap and possible competition between honeybees and wild bees in central Europe. Oecologia, 122, 288-296.

Stoate C., Boatman N.D., Borralho R.J., Carvalho C.R., de Snoo G.R. \& Eden P. (2001) Ecological impacts of arable intensification in Europe. J. Environ. Manage., 63, 337-365.

Svensson, B., Lagerlöf, J., Svensson, B.G. (2000) Habitat preferences of nest-seeking bumble bees (Hymenoptera: Apidae) in an agricultural landscape Agr. Ecosyst. Environ., 77, 247-255.

Thorbek P. \& Bilde T. (2004) Reduced numbers of generalist arthropod predators after crop management. J. Appl. Ecol., 41, 526-538.

Tscharntke T., Rand T.A. \& Bianchi F.J.J.A. (2005) The landscape context of trophic interactions: insect spillover across the crop-noncrop interface. Ann. Zool. Fennici, 42, 421-432.

Visscher P.K. \& Seeley T.D. (1982) Foraging Strategy of Honeybee Colonies in a Temperate Deciduous Forest. Ecology, 63, 1790-1801.

Weibull A.-C., Östman Ö. \& Granquist A. (2003) Species richness in agroecosystems: the effect of landscape, habitat and farm management. Biodivers. Conserv.,12, 1335-1355.

Westphal C., Steffan-Dewenter I. \& Tscharntke T. (2003) Mass flowering crops enhance pollinator densities at a landscape scale. Ecol. Lett., 6, 961-965.

Westrich, P. (1996) Habitat requirements of central European bees and the problems of partial habitats. Pages 1-16 in A. Matheson, S.L. Buchmann, C.O`Toole, P.Westrich and I.H. Westrich, editors. The conservation of bees. Academic press, London, UK. 


\title{
Chapter 4
}

\section{Landscape context, organic farming and fallow strips influence nest colonization of bees and wasps}

\begin{abstract}
Increasing land-use intensity has led to more intensive farming practices at the local scale and the loss of noncrop habitats at the landscape scale. Little is known how species depending on resources in noncrop habitats perceive crop-noncrop interfaces and crop fields differing in farming intensity.

In a two-year study, we analysed effects of agricultural intensification on nest colonization of cavity-nesting bees, wasps and their natural enemies at three hierarchical spatial scales. We selected 23 pairs of conventionally and organically cultivated wheat fields along landscape gradients from low to high edge densities and from low to high proportions of noncrop habitats in a $500 \mathrm{~m}$ radius around fields (altogether 46 study fields). Standardized nesting sites were established in field centres and in permanent fallow strips adjacent to the fields.
\end{abstract}

Species richness and abundance of wasps and bees increased with increasing edge densities and proportions of noncrop habitats, respectively. At the local scale, organic farming enhanced species richness and abundance of bees in both field centres and adjacent fallow strips suggesting that bees nesting in neighbouring noncrop habitats benefited from resources in organic wheat fields. Wasp abundance and species richness was greatly enhanced by organic farming in annual crop fields, but not in fallow strips. 
Nest colonization of wasps was higher in fallow strips than in field centres independently from the farming system of the adjacent field. Presumably, wasps mainly dispersed along fallow strips and preferred nesting sites in noncrop habitats, whereas bees appeared to be attracted by the high nectar and pollen resources in organic fields.

Our results emphasize the impact of source habitats at a landscape scale for crop field colonization. Further, bees and wasps were noncrop specialists that still responded to the resource differences provided by organic compared to conventional fields. We conclude that colonization processes may suffer from the destruction of noncrop nest habitats, but low-intensity farming may compensate for the loss of noncrop foraging habitats and reduce fragmentation of foraging habitats.

\section{Keywords}

agri-environment schemes, biodiversity, field margins, pollinators, predators, spatial scale, trap nests, trophic interactions, winter wheat 


\section{Introduction}

Increasing land-use intensity is the most serious threat to biodiversity in agroecosystems (Krebs et al. 1999, Benton et al. 2003). During the expansion of farmland in the last 2000 years, many species have adapted to the regularly disturbed habitats and agricultural landscapes became very species-rich ecosystems. Natural open landscapes such as inland dunes, moors and river flood-plains, which were the primary habitats of these species, have nearly disappeared in Central Europe and many species now completely depend on manmade habitats (Küster 1999).

In the last decades, the increase of land-use intensity, which is coupled with the enhancement of agricultural production, changed agroecosystems in multiple ways and at several spatial scales. At the local scale, farming intensity increased with the increase of agrochemical applications and the reduction of crop rotations (Stoate et al. 2001). At the landscape scale, annual crop fields expanded at the cost of noncrop habitats, which provide permanent refuges, nesting and foraging sites (Tilman et al. 2001, Benton et al. 2003). Field sizes increased and field edges, where crops are less intensively managed than in field centres, decreased (Marshall \& Moonen 2002). The decline of field edges in relation to total field sizes may restrict recolonization processes from adjacent noncrop habitats into the regularly disturbed crop fields (Landis et al. 2000). Further, linear noncrop structures such as permanent grass strips and hedges serving as refuges and hibernation habitats have been reduced (Stoate et al. 2001).

Agri-environment schemes target to counteract the current decline of biodiversity by reversing parts of the intensification process (Krebs et al. 1999). Measurements promoted by agri-environment schemes include low-intensity farming such as organic farming and the creation of noncrop strips along field boundaries. Farmers adopting those schemes receive compensation payments for their production losses. However, the benefits provided by agri-environment schemes for biodiversity have been discussed controversially (Kleijn et al. 2001, Kleijn \& Southerland 2003, Vickery et al. 2004, Hole et al. 2005, Pywell et al. 2006). Studies examining larger scales than local habitats suggested that heterogeneous landscapes with many and diverse noncrop habitats 
enhance farmland species more than local improvements of farming (Weibull et al. 2003, Bengtsson et al. 2005, Clough et al. 2005). Further, the effect of agri-environment schemes on rare species including many specialists seems to be very small (Kleijn et al. 2006). Positive effects of agri-environment schemes promoting low-intensity crop farming may be highest for generalist species adapted to crop fields and depending on noncrop habitats for hibernation and refuges during disturbances only. Those species may benefit, depending on the trophic level, from the absence of pesticides in organic fields, the more abundant and diverse weed flora or the increase of resources associated with noncrop plants (Bengtsson et al. 2005, Roschewitz et al. 2005, Schmidt et al. 2005).

In contrary, species requiring resources provided by traditionally managed noncrop habitats may suffer from habitat destruction at a landscape scale rather than from intensive management of crop fields. However, also species depending on resources in noncrop habitats may frequent crop fields and couple processes of noncrop and crop habitats (Rand et al. 2006). Mass-flowering crops often depend on pollination by bees nesting in natural habitats (Kremen et al. 2002), and food resources from massflowering crops may enhance abundances of bumble bees in fallows at a landscape scale (Westphal et al. 2003), but effects of farming intensity seem to be small compared to benefits from nesting habitats in the surrounding (Kremen et al. 2004). However, little is known about how species depending on resources in noncrop habitats perceive cropnoncrop interfaces and crop fields differing in farming intensity.

The purpose of our study was to examine how land-use intensity at landscape and local scales influences nest colonization of cavity-nesting bees and wasps which are specialized to nest in noncrop habitats. Further, we tested how interactions with natural enemies are influenced by land-use intensity. We established standardized nesting sites in organic and conventional wheat fields and adjacent fallow strips. In a hierarchical design, we analysed effects of landscape context (gradients of edge density and proportion of noncrop habitats in landscape sectors with $500 \mathrm{~m}$ radius), farming system (organic vs. conventional) and location (highly disturbed field centre vs. permanent fallow strip) on nest colonization of wasps, bees and their natural enemies. 
First, we tested the hypothesis that nest colonization increases with high edge densities and high proportions of noncrop habitats providing source populations at a landscape scale. Second, assuming higher resource availability in organic fields, we hypothesized that organic farming has a positive effect compared to conventional farming on nest colonization. Third, we hypothesized that nest colonization is higher in fallow strips than in field centres, because dispersing bees, wasps and natural enemies prefer to move along linear fallow strips adjacent to crop fields instead of crossing crop fields.

\section{Methods}

\section{Study region and study sites}

The study was conducted in 2003 and 2004 in 46 winter wheat fields and adjacent permanent fallow strips in the surrounding of Göttingen, Lower-Saxony $\left(51^{\circ} 32^{\prime} 00^{\prime \prime} \mathrm{N}\right.$ $\left.009^{\circ} 56^{\prime} 00^{\prime \prime} \mathrm{E}\right)$. In the study region, very intensively used fertile soils in flat parts of the region alternate with less intensively used agricultural landscapes in hilly parts. Wheat is the most important arable crop in the study region as well as in most agricultural regions in Germany (Statistisches Bundesamt 2004).

Within the region, we selected 12 study areas to encompass landscape gradients from crop-dominated to noncrop-dominated landscapes and from low to high edge densities. Within each study area, a pair of organic and conventional winter wheat fields was selected for each year. Due to crop rotation, field pairs within a study area were not the same in 2003 and 2004. In total, we studied 23 field pairs in 12 study areas, because no wheat fields were managed organically in one of the study areas in 2004. Organic wheat fields were farmed according to the European Union regulation 2092/91/EEC, which prohibits the use of synthetic fertilisers and pesticides. Instead of synthetic fertilisers, organic farmers applied animal and green manure and included legumes in the crop rotation for replenishing the soil resources. Weeds were managed mechanically or by effective crop rotations.

Each organic field was paired with the first nearby conventional winter wheat field for a comparison of farming systems which controlled for differences in abiotic conditions and landscape context. Distances between fields within a pair ranged from $0 \mathrm{~m}$ to $600 \mathrm{~m}$ 
and between study areas from 3 to $43 \mathrm{~km}$. Mean field size was $4.5 \pm 0.5$ ha (SE) and did not differ between the two farming types (ANOVA: $\mathrm{F}=2.6, \mathrm{P}=0.118$ ).

One side of each field was flanked by a permanent fallow strip between the field boundary and a farm track. Fallow strips were long established, had a naturally developed herb and grass layer, and mostly included a narrow ditch. The occurrence of a ditch and the management (mowing) of fallow strips did not differ between strips adjacent to organic and conventional fields. Mean fallow strip width was $3.0 \pm 0.2 \mathrm{~m}$ (SE) and did not differ between fallow strips adjacent to conventional or organic fields (ANOVA: $\mathrm{F}=1.1, \mathrm{P}=0.309$ ).

We established an standardized nesting site in the centre of each field and each fallow strip (altogether 92 nest sites: 23 field pairs x 2 farming systems x 2 locations). In conventional fields, farmers did not apply insecticides within a $15 \times 15$ m quadrate with the nesting site in the centre.

\section{Trap nest communities}

Standardized nesting sites ("trap nests") enabled us to study nest colonization of cavitynesting bees, wasps and their natural enemies under standardised nest site conditions (Tscharntke et al. 1998). Trap nests were composed of two trap nest tubes fitted on a wooden pole at a height of 1.0-1.2 m and shaded by a 41 x $50 \mathrm{~cm}$ chipboard roof. Each trap nest tube consisted of 150-18020 cm long internodes of common reed Phragmites australis, which were put into a $10.5 \mathrm{~cm}$ diameter plastic tube. The diameters of reed internodes ranged from 2 to $10 \mathrm{~mm}$. Trap nests were in the field from mid-April until harvest end-July. In the laboratory, all reed internodes containing nests were opened. For each nest, the genus of bee or wasp larvae, the number of brood cells and the occurrence of natural enemies were recorded (Gathmann \& Tscharntke 1999). Most larvae of bees, wasps and natural enemies were identified to the species level. All nests were reared separately to get the adults of bees, wasps and their natural enemies for final species identification. In some cases, no adults emerged or all brood cells were parasitized, so that only the genus could be identified. These nests were included in the analyses as additional species if no other species of this genus were found at the same study site. 
Species richness represented the total number of species, abundance the total number of brood cells of bees, wasps and natural enemies from four trap nests per study site. The mortality rate was the number of parasitized or predated brood cells divided by the total number of brood cells per study site. Data were separately analysed for four functional groups: predatory wasps (Sphecidae, Eumeninae, Pompilidae), bees (Apiformes), natural enemies of wasps and natural enemies of bees.

\section{Landscape context}

For each wheat field, the surrounding landscape was characterised in a circular landscape sector with the field in the centre and a radius of $500 \mathrm{~m}$. The radius was chosen according to results of previous studies on trap-nesting bees and wasps (Gathmann \& Tscharntke 2002, Steffan-Dewenter 2002). Field inspections were made in these landscape sectors on the base of official topographical maps (DGK 1:5000) in 2003 and 2004. We calculated edge density (total length of patch edges divided by total area) and the proportion of noncrop habitats in each landscape sector for each year using Geographic Information Systems (GIS; Topol 4.506, Gesellschaft für digitale Erdbeobachtung und Geoinformation mbH, Göttingen, Germany and ARC/View 3.2., ESRI Geoinformatik GmbH, Hannover, Germany). Landscape parameters for landscape sectors around organic and conventional fields forming a pair were averaged for each year. We used Spearman rank correlations to test for correlations between landscape parameters. The proportion of noncrop habitats was highly positively correlated with the Shannon-index of habitat diversity in both years $(\mathrm{R}=0.9, \mathrm{P}<0.005)$, but not with edge density $(\mathrm{R}=0.2, \mathrm{P}>0.4)$.

\section{Statistics}

We used linear mixed-effects models (Pinheiro \& Bates 2000) to analyse effects on species richness and number of brood cells of wasps and bees. Edge density, \% noncrop habitats, farming system (organic vs. conventional) and location (field centre vs. fallow strip) were considered as fixed factors, study area and year as random factors. 
The following error structure was incorporated in the models (number of levels indicated in parentheses): "study area" (12)/ "year" (2)/ "farming system" (2)/ "location" (2). We used Wald tests to test for significance of fixed effects and interactions among them. Fixed factors and interactions which did not contribute to the model with $\mathrm{P}<0.05$ were removed in a stepwise backward procedure from the full model. Response variables were transformed $(\log 10(x+1))$. All statistical analyses were performed using R (R Development Core Team 2004). 


\section{Results}

In total, 11275 brood cells of 10 wasp species (2631 brood cells) and 7 bee species (8266 brood cells of Osmia rufa, 378 brood cells of other bee species) were collected from 92 trap nest sites (184 trap nest tubes). Further, we recorded 12 species of natural enemies. Three species of natural enemies attacked wasps, six species attacked bees and three species were found in both bee and wasp nests. The mean mortality by natural enemies was $21.9 \pm \% 3.2(\mathrm{SE})$ for wasps and $24.2 \pm 1.8 \%(\mathrm{SE})$ for bees.

Table 1: Final linear mixed-effects models describing the effects of edge density and proportion of noncrop habitat (in landscape sectors with $500 \mathrm{~m}$ radius), farming system (organic vs. conventional), location (field centre vs. fallow strips) and their interactions on species richness and number of brood cells of wasps, bees and their natural enemies. Non-significant factors and interactions were removed in a stepwise backward procedure from the full model.

\begin{tabular}{|c|c|c|c|c|c|c|}
\hline & \multicolumn{3}{|c|}{ Hosts } & \multicolumn{3}{|c|}{ Natural enemies } \\
\hline & DF & $\mathrm{F}$ & $\mathrm{P}$ & DF & $\mathrm{F}$ & $\mathrm{P}$ \\
\hline \multicolumn{7}{|l|}{ Wasps and Natural enemies } \\
\hline \multicolumn{7}{|l|}{ Species richness } \\
\hline edge density & 1,10 & 7.4 & 0.022 & & & \\
\hline farming system & 1,22 & 8.3 & 0.009 & 1,22 & 3.8 & 0.062 \\
\hline location & 1,45 & 22.6 & $<0.001$ & & & \\
\hline \multicolumn{7}{|l|}{ Number of brood cells } \\
\hline edge density & 1,10 & 5.2 & 0.046 & & & \\
\hline farming system & 1,22 & 6.9 & 0.016 & & & \\
\hline location & 1,44 & 19.8 & $<0.001$ & 1,44 & 15.3 & $<0.001$ \\
\hline farming system $\mathrm{x}$ location & 1,44 & 4.6 & 0.038 & 1,44 & 3.2 & 0.081 \\
\hline \multicolumn{7}{|l|}{ Bees and Natural enemies } \\
\hline \multicolumn{7}{|l|}{ Species richness } \\
\hline proportion of noncrop habitats & 1,10 & 13.8 & 0.004 & 1,10 & 9.1 & 0.012 \\
\hline farming system & 1,22 & 4.7 & 0.041 & & & \\
\hline location & 1,45 & 6.6 & 0.014 & 1,45 & 6.4 & 0.015 \\
\hline \multicolumn{7}{|l|}{ Number of brood cells } \\
\hline proportion of noncrop habitats & 1,10 & 6.9 & 0.025 & 1,10 & 3.3 & 0.100 \\
\hline farming system & 1,22 & 4.1 & 0.056 & 1.22 & 4.1 & 0.055 \\
\hline location & 1,45 & 3.2 & 0.080 & 1,45 & 5.6 & 0.022 \\
\hline
\end{tabular}


Colonization of standardized nesting sites in organic and conventional fields and adjacent fallow strips was related to the surrounding landscape, the farming system (organic vs. conventional) and the habitat type (field centre vs. fallow strip) (Table 1). Species richness and number of brood cells of both wasps and bees were higher in organic than in conventional sites and higher in fallow strips than in field centres (Fig. 1). In fallow strips adjacent to organic fields, the number of wasp brood cells increased by $85 \%$ compared to organic fields and in fallow strips adjacent to conventional fields by more than $700 \%$ compared to conventional fields. The positive effect of organic farming on species richness of wasps was more pronounced in field centres than in adjacent fallow strips. A significant interaction between farming system and location for wasp abundance showed that the farming system influenced wasps in field centres and fallow strips differently. While the mean number of wasp brood cells in organic fields was 4.5 times as high as in conventional fields, the number of wasp brood cells in fallow strips were not influenced by the farming system of the adjacent field.
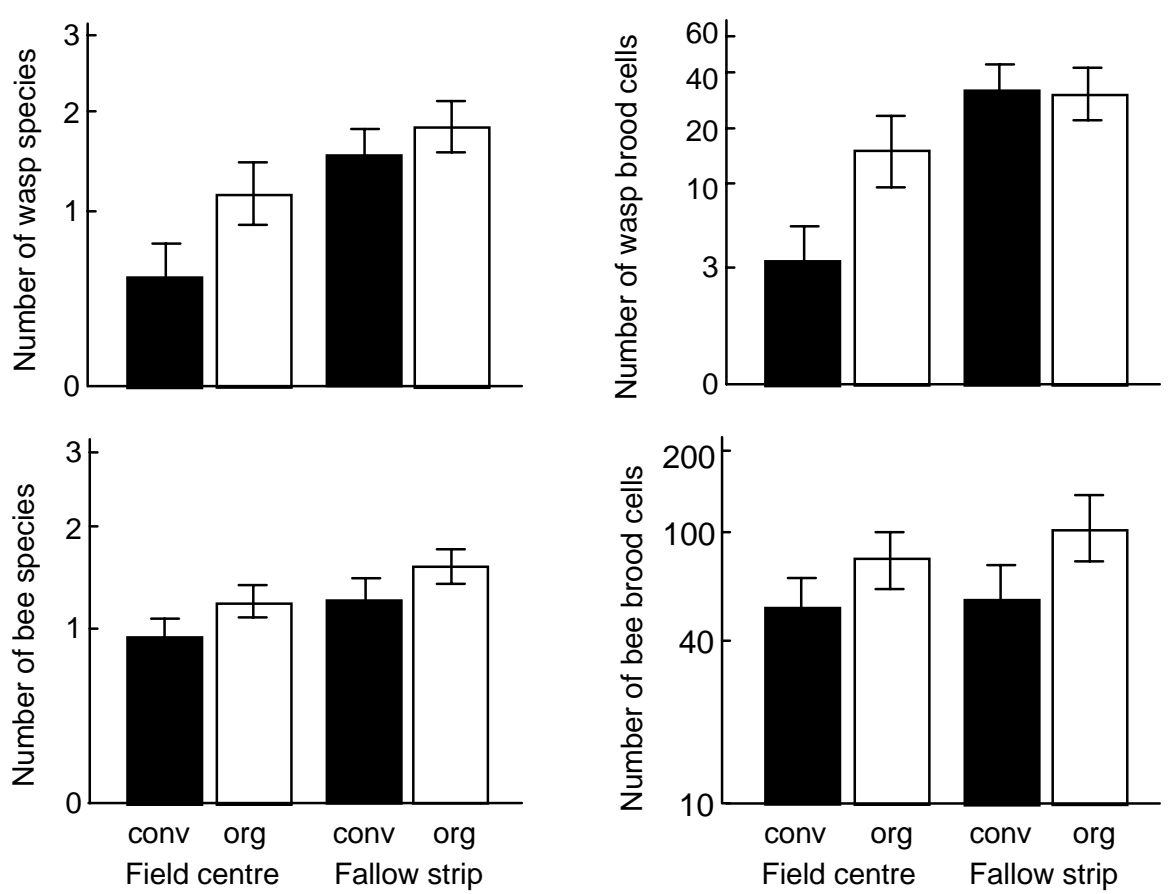

Fig. 1 Species richness and number of brood cells of wasps and bees in conventional (black bars) and organic (white bars) fields and adjacent fallow strips. Results are from mixed-effects models (see Table 1). Data of the two study years were averaged for each of the four site types per study area (conventional/organic field /fallow strip). Means and standard errors are shown. 
Positive effects of organic farming and fallow strips on bees were comparably low, and for the number of bee brood cells marginally significant only (Table 1). The farming system influenced bees in fields and adjacent fallow strips similarly (Fig. 1). The number of brood cells was $50 \%$ higher in organic than in conventional fields and $80 \%$ higher in fallow strips adjacent to organic than adjacent to conventional fields. Fallow strips enhanced the number of bee brood cells by $20 \%$ compared to fields.
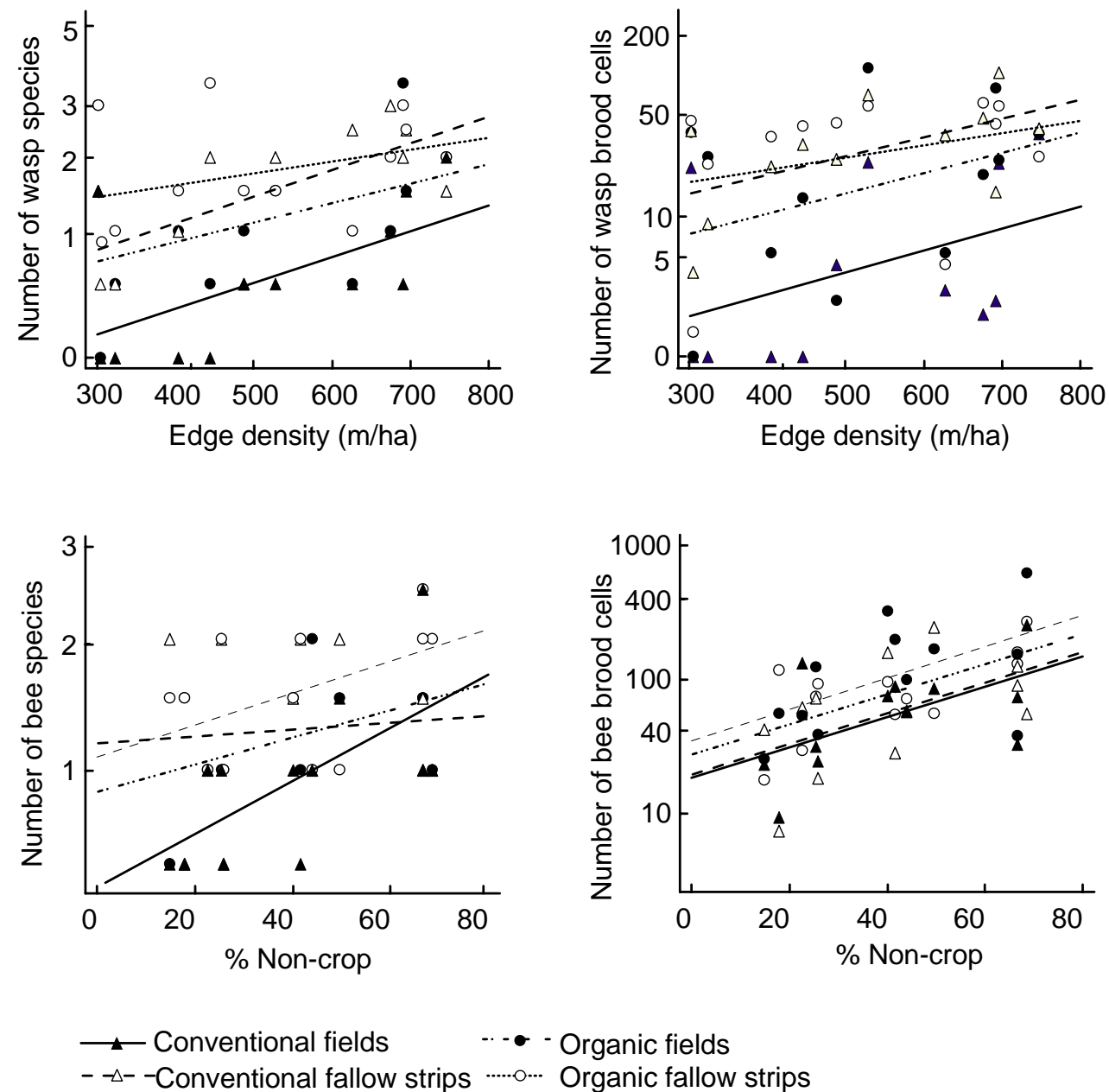

Fig. 2 Effects of landscape context (edge density and \% noncrop fields in $500 \mathrm{~m}$ radius) on species richness and number of brood cells of wasps and bees. Results are from mixed-effects models (see Table 1). Data of the two study years were averaged for each of the four site types per study area (conventional/organic field centre/fallow strip). 
At the landscape scale, wasp species richness and number of brood cells increased with increasing edge density in landscape sectors with $500 \mathrm{~m}$ radius around study sites (Table 1, Fig. 2). The proportion of noncrop habitats had no additional explanatory power. According to our data, a doubling of edge density from $350 \mathrm{~m}$ to $700 \mathrm{~m}$ edge per ha resulted in $260 \%$ more wasp brood cells. Species richness and number of brood cells of bees were positively related to the proportion of noncrop habitats in $500 \mathrm{~m}$ radius, but not to edge density (Table 1, Fig. 2). A doubling of noncrop habitats in a landscape sector from 30 to $60 \%$ resulted in a brood cell increase of more than $100 \%$. There were no interactions between landscape factors and farming system or trap nest location indicating that landscape effects were not significantly modified by local effects.

Natural enemies of bees and wasps were less strongly affected by land-use intensity at landscape and local scales than their hosts (Table 1). We did not find effects on parasitism rates or number of enemy species per host species (in all cases $\mathrm{P}>0.1$ ).

\section{Discussion}

Nest colonization of wasps and bees in agricultural landscapes greatly depended on factors associated with agricultural intensification at landscape and local scales. Effects of landscape heterogeneity (gradients of edge density and \% noncrop habitats in $500 \mathrm{~m}$ radius), farming system (organic vs. conventional wheat fields) and nest location (highly disturbed field centres vs. naturally developed fallow strips) all contributed to determine abundance and species richness of cavity-nesting bees and wasps. While effects at the landscape scale showed the importance of noncrop areas as source habitats providing the only natural nesting sites, effects at local scales highlighted the impact of food resources and of dispersal along linear structures for nest colonization.

\section{Landscape scale}

Nest colonization of wasps and bees was highest in landscapes with high edge densities and high proportions of noncrop habitats, respectively. The importance of a landscape perspective for the understanding of community structure and biotic interactions has increasingly been recognized (Kareiva 1990, Tischendorf \& Fahrig 2000, Tscharntke et 
al. 2005). The impact of landscape context can override effects of local farming practices (Bengtsson et al. 2005, Schmidt et al. 2005, Clough et al. 2005) or modify local effects, e.g. intensively used landscapes can enhance differences between organic and conventional fields by reducing plant diversity in conventional fields more strongly than in organic fields (Roschewitz et al. 2005).

Both, proportion of noncrop habitats and edge density may be positively correlated with the availability of source habitats which are restricted to old trees and hedgerows in noncrop habitats and in linear noncrop structures along field edges. Furthermore, noncrop habitats and field edges may serve as alternative foraging habitats if local food availability in fields and fallow strips is subject to temporal fluctuations. This is in accord with results of translocation experiments showing that foraging distances of cavity-nesting bees range between 150 and $600 \mathrm{~m}$ (Gathmann \& Tscharntke 2002). The importance of landscape configuration (edge density) instead of landscape composition (proportion of noncrop habitats) on wasp colonization suggests that field edges facilitated movements between source habitats and newly colonized nests. If dispersing wasps preferred to move along linear edge structures, high densities of field edges connecting nest habitats and serving as movement conduits may be more important for colonization processes than the quantity of otherwise isolated source habitats (Ricketts 2001, Fried et al. 2005).

\section{Local scales}

Although cavity-nesting wasps and bees are highly specialized on nests in noncrop habitats, they colonized standardized nests in the centre of wheat fields. This suggests that even noncrop specialists do not generally perceive cereal fields as non-habitats and hostile landscape matrix. The positive effect of organic compared to conventional farming underlines the impact of local food availability on nest colonization (Tscharntke et al. 1998) and revealed the potential importance of cereal fields in providing those food resources.

The absence of agrochemicals in organic fields enhances noncrop vegetation and associated organism groups (Bengtsson et al. 2005, Roschewitz et al. 2005, Schmidt et al. 2005). While bees may benefit from a higher abundance and diversity of flowering 
plants in organic fields, predatory wasps may additionally prefer organic fields due to a higher abundance of spiders and lepidopteran larvae, which are used for nest provision by the most abundant sphecid and eumenid wasps (Tscharntke et al. 1998). The influence of organic farming on wasp and bee communities in field centres confirm its potential to support weed-associated and predatory species (Hole et al. 2005, Bengtsson et al. 2005). In contrast to other studies on effects of farming systems, our results report a higher nest colonization and reproduction in organic fields instead of pure individual and species numbers. As high nest colonization may be linked to high population viability, we conclude that organically farmed wheat fields may contribute to resources even valuable for noncrop specialists.

Field margin strips are considered as valuable bee foraging habitats, because of a high flower availability compared to cereal fields (Fussel \& Corbet 1991, Bäckmann \& Tiainen 2002, Pywell et al. 2005, Pywell et al. 2006). According to our data, benefits from organic farming on bee colonization overrode benefits provided by fallow strips probably due to the high species richness and cover of flowering plants in organic compared to conventional fields (A. Holzschuh, unpubl. data). The small differences in nest colonization between field centres and fallow strips as well as the positive effect of organic fields on nests in adjacent fallow strips indicates that nest colonization was rather influenced by resources provided in organic wheat fields than in fallow strips. Furthermore, similar nest colonization in field centres and fallow strips suggests that bees did not distinguish between cereal fields and noncrop habitats during dispersal and did not prefer to disperse along linear boundary structures.

In contrast, wasps greatly benefited from fallow strips. Nest colonization was higher in fallow strips than in centres of adjacent fields of both farming systems. This suggests that wasps prefer to follow linear edge structures during dispersal and underlines the role of edge density for colonization at a landscape scale. Although there were differences between farming systems in field centres, nest colonization did not differ between fallow strips adjacent to organic and conventional fields. Apparently, wasps nesting in fallow strips foraged primarily in fallow strips themselves and did not benefit from resources provided in fields.

Both, effects at landscape and local scales indicate that wasps and bees perceive agricultural landscapes differently instead of similar nesting requirements and dispersal 
ranges (Steffan-Dewenter 2002). Differences in bee and wasp behaviour may result from high patchiness and fluctuations of flower resources in agricultural landscapes forcing bees to forage at larger scales and to move independently from noncrop corridors. In contrast, prey for predatory wasps may be abundant in nesting habitats resulting in foraging movements in the vicinity of nesting sites and dispersal movements restricted to noncrop habitat corridors.

In contrary to expectations, agricultural intensification did not influence interactions between bees or wasps and their natural enemies. Parasitism rates or the number of natural enemy species per host species did not depend on landscape context, farming system or location. There is some evidence that higher trophic levels suffer more from habitat isolation than their hosts (Kruess \& Tscharntke 1994, Thies \& Tscharntke 1999). Theory predicts that higher trophic levels have lower abundances and are more dependent on recolonization processes, because they are more affected by frequent disturbances and local population extinctions (Holt 2002). Local population dynamics of host species make them an unstable resource for species of higher trophic levels. Furthermore, natural enemies can have more restrictive dispersal abilities and perceive isolation at smaller scales than their hosts (van Nouhuys \& Hanski 2002), but dispersal behaviour does not necessarily correspond to trophic level (van Nouhuys 2005). According to our results, natural enemies colonized new nest sites as rapidly as their hosts, and bees and wasps were not able to avoid parasitism by colonizing nests in field centres or in homogeneous landscapes with low edge densities or low proportions of noncrop habitats.

According to our study, nest colonization was influenced by land-use intensity at both local and landscapes scales and depended on the sum of effects at different spatial scales. This suggests that agri-environments schemes promoting low land-use intensity may substitute each other to a certain degree. Advantages provided at one scale may compensate disadvantages of intensification at another scale. As noncrop species frequented cereal fields, they may couple processes of crop and noncrop habitats (Rand et al. 2006), and nest colonization in the vicinity of crop fields may influence pollination by bees and biological control by wasps in those fields. However, further habitat fragmentation may threat colonization processes by isolating nesting sites in noncrop habitats. 
Acknowledgments: We thank the farmers for their participation in the project, Doreen Gabriel for GIS-support and Gundula Kolb for her help with the dissection of trap nests. This research was carried out within the framework of the EU-funded project 'EASY' (QLK5-CT-2002-01495) coordinated by David Kleijn.

\section{References}

Bäckmann J.-P.C. \& Tiainen J. (2002) Habitat quality of field margins in a Finnish farmland area for bumblebees (Hymenoptera: Bombus and Psithyrus). Agriculture, Ecosystems \& Environment, 89, 53-68.

Bengtsson J., Ahnström J. \& Weibull A.-C. (2005) The effects of organic agriculture on biodiversity and abundance: a meta-analysis. Journal of Applied Ecology, 42, 261-269.

Benton T.G., Vickery J.A. \& Wilson J.D. (2003) Farmland biodiversity: is habitat heterogeneity the key? Trends in Ecology and Evolution, 18, 182-188.

Clough Y., Kruess A., Kleijn D. \& Tscharntke T. (2005) Spider diversity in cereal fields: comparing factors at local, landscape and regional scales. Journal of Biogeography, 32, 2007-2014.

Fried J.H., Levey D.J. \& Hogsette J. (2005) Habitat corridors function as both drift fences and movement conduits for dispersing flies. Oecologia, 143, 645-651.

Fussell M. \& Corbet S.A. (1991) Forage for bumble bees and honey bees in farmland: A case study. Journal of Apicultural Research, 30, 87-97.

Gathmann A. \& Tscharntke T. (2002) Foraging ranges of solitary bees. Journal of Animal Ecology, 71, 757-764.

Hole D.G., Perkins A.J., Wilson J.D., Alexander I.H., Grice P.V. \& Evans A.D. (2005) Does organic farming benefit biodiversity? Biological Conservation, 122, 113-130.

Holt R.D. (2002) Food webs in space: On the interplay of dynamic instability and spatial processes. Ecological Research, 17, 261-273.

Kareiva P. (1990) Population-dynamics in spatially complex environments - theory and data. Philosophical Transactions of the Royal Society of London Series B-Biological Sciences, 330, 175-190. 
Kleijn D., Baquero R.A., Clough Y., Diaz M., De Esteban J., Fernandez F., Gabriel D., Herzog F., Holzschuh A., Johl R., Knop E., Kruess A., Marshall E.J.P., Steffan-Dewenter I., Tscharntke T., Verhulst J., West T.M. \& Yela J.L. (2006) Mixed biodiversity benefits of agri-environment schemes in five European countries. Ecology Letters, 9, 243-254.

Kleijn D., Berendsen F., Smit R. \& Gilisen N. (2001) Agri-environment schemes do not effectively protect biodiversity in Dutch agricultural landscapes. Nature, 413, 723-725.

Kleijn D. \& Sutherland W.J. (2003) How effective are European agri-environment schemes in conserving and promoting biodiversity? Journal of Applied Ecology, 40, 947-969.

Krebs J.R., Wilson J.D., Bradbury R.B. \& Siriwardena G.M. (1999) The second silent spring. Nature, 400, 611-612.

Kremen C., Williams N.M., Bugg R.L., Fay J.P. \& Thorp R.W. (2004) The area requirements of an ecosystem service: crop pollination by native bee communities in California. Ecology Letters, 7, 1109-1119.

Kremen C., Williams N.M. \& Thorp R.W. (2002) Crop pollination from native bees at risk from agricultural intensification. Proceedings of the National Academy of Sciences of the USA, 99, $16812-16816$

Kruess A. \& Tscharntke T. (1994) Habitat fragmentation, species loss, and biological-control. Science, 264, 1581-1584.

Küster H. (1999) Geschichte der Landschaft in Mitteleuropa. Beck, München, Germany.

Landis D.A., Wratten S.D. \& Gurr G.M. (2000) Habitat management to conserve natural enemies of arthropod pests in agriculture. Annual Review of Entomology, 45, 175-201.

Marshall E.J.P. \& Moonen A.C. (2002) Field margins in northern Europe: their functions and interactions with agriculture. Agriculture, Ecosystems and Environment, 89, 5-21.

Pinheiro J.B. \& Bates D.M. (2000) Mixed-effects models in S and S-Plus. Springer, New York.

Pywell R.F., Warman E.A., Carvell C., Sparks T.H., Dicks L.V., Bennett D., Wright A., Critchley C.N.R. \& Sherwood A. (2005) Providing foraging resources for bumblebees in intensively farmed landscapes. Biological Conservation, 121, 479-494.

Pywell R.F., Warman E.A., Hulmes L., Hulmes S., Nuttall P., Sparks T.H., Critchley C.N.R. \& Sherwood A. (2006) Effectiveness of new agri-environment schemes in providing foraging resources for bumblebees in intensively farmed landscapes. Biological Conservation, 129, 192-206. 
R Development Core Team (2004) R: A language and environment for statistical computing. Foundation for Statistical Computing, Vienna.

Rand T.A., Tylianakis J.M. \& Tscharntke T. (2006) Spillover edge effects: the dispersal of agriculturallysubsidized insect natural enemies into adjacent natural habitats. Ecology Letters (in press).

Ricketts T.H. (2001) The matrix matters: effective isolation in fragmented landscapes. American Naturalist, 158, 87-99.

Roschewitz I., Gabriel D., Tscharntke T. \& Thies C. (2005) The effects of landscape complexity on arable weed species diversity in organic and conventional farming. Journal of Applied Ecology, 42, 873-882.

Schmidt M.H., Roschewitz I., Thies C. \& Tscharntke T. (2005) Differential effects of landscape and management on diversity and density of ground-dwelling farmland spiders. Journal of Applied Ecology, 42, 281-287.

Statistisches Bundesamt (2004) Landwirtschaft in Zahlen 2003, Wiesbaden. http://www.destatis.de/download/d/veroe/faltblatt/landw2003.pdf

Steffan-Dewenter I. (2002) Landscape context affects trap-nesting bees, wasps and their natural enemies. Ecological Entomology, 27, 631-637.

Stoate C., Boatman N.D., Borralho R.J., Carvalho C.R., de Snoo G.R. \& Eden P. (2001) Ecological impacts of arable intensification in Europe. Journal of Environmental Management, 63, 337-365.

Thies C. \& Tscharntke T. (1999) Landscape structure and biological control in agroecosystems. Science, 285, 893-895.

Tilman D., Fargione J., Wolff B., D'Antonio C., Dobson A., Howarth R., Schindler D., Schlesinger W.H., Simberloff D. \& Swackhamer D. (2001) Forecasting agriculturally driven global environmental change. Science, 292, 281-284.

Tischendorf L. \& Fahrig L. (2000) On the usage and measurement of landscape connectivity. Oikos, 90, 7-19.

Tscharntke T., Gathmann A. \& Steffan-Dewenter I. (1998) Bioindication using trap-nesting bees and wasps and their natural enemies: community structure and interactions. Journal of Applied Ecology, 35, 708-719.

Tscharntke T., Klein A.M., Steffan-Dewenter I. \& Thies C. (2005) Landscape perspectives on agricultural intensification and biodiversity - ecosystem service management. Ecology Letters, 8, 857-874. 
van Nouhuys S. \& Hanski I. (2002) Colonization rates and distances of a host butterfly and two specific parasitoids in a fragmented landscape. Journal of Animal Ecology, 71, 639-650.

van Nouhuys S. (2005) Effects of habitat fragmentation at different trophic levels in insect communities. Annales Zoologici Fennici, 42, 433-447.

Vickery J.A., Bradbury R.B., Henderson I.G., Eaton M.A. \& Grice P.V. (2004) The role of agrienvironment schemes and farm management practices in reversing the decline of farmland birds in England. Biological Conservation, 119, 19-39.

Weibull A.-C., Östman Ö. \& Granquist A. (2003) Species richness in agroecosystems: the effect of landscape, habitat and farm management. Biodiversity and Conservation, 12, 1335-1355.

Westphal C., Steffan-Dewenter I. \& Tscharntke T. (2003) Mass flowering crops enhance pollinator densities at a landscape scale. Ecology Letters, 6, 961-965. 


\title{
Chapter 5
}

\section{Grassy corridors in cropland landscapes enhance nest site colonization of solitary wasps}

\begin{abstract}
Habitat fragmentation results in serious biodiversity declines by disrupting movements between habitat patches. Corridors that connect otherwise isolated habitats have been often proposed as a management strategy to mitigate negative impacts of habitat fragmentation. However effects of corridors in real landscapes have been rarely examined and the role of grassy strips in cropland landscapes is totally unknown. Further, we do not know whether the more fragmentation-sensitive species at higher trophic levels benefit from corridors.
\end{abstract}

In twelve agricultural landscapes (each $4-6 \mathrm{~km}^{2}$ in size), we examined effects of corridors on communities of above-ground nesting bees and wasps and their natural enemies. In each landscape, we compared six treatments at different distances from a forest edge as potential source habitat. We experimentally exposed standardized nest patches in a forest edge (A), in hedges $(\mathrm{B}, \mathrm{C})$ and in grass strips (D-F). They were connected with a forest edge $(\mathrm{B}, \mathrm{D})$, slightly isolated $(200 \mathrm{~m})(\mathrm{E})$ or highly isolated (> $600 \mathrm{~m})(\mathrm{C}, \mathrm{F})$.

Species richness and number of brood cells of wasps were highest in nest patches close to forest edges and hedges showing their potential as source habitats for solitary wasps. Grass strip corridors clearly facilitated movements of wasps. When nest patches were connected with the nearest forest edge by a grass strip, the number of wasp brood cells in the nest patch was four times higher than in isolated nest patches. However, the number of wasp brood cells in hedges connected to a forest edge was not higher than in isolated hedges suggesting that hedges are self-sustained habitats. 
Forest edges did not prove to be source habitats for bees and consequently our study design did not enable us to test on corridor function for bees. Natural enemies largely reflected the patterns found for their hosts, and mortality due to natural enemies did not depend on habitat type or presence of a corridor. However, the mortality of the dominant bee Osmia rufa was higher in hedges than in grass strips suggesting that its natural enemies were more restricted in their ability to colonize open habitats than the host species.

We conclude that grass strip corridors facilitate movements of wasps and enhance colonization of nest patches. In agricultural landscapes, where nesting sites are limited and food availability changes frequently, rapid colonization of nest patches may be linked to high population viability. Although grass strips can reduce the negative effects of habitat fragmentation, source habitats such as forest edges and hedges are required within the dispersal range of wasps to afford colonization processes.

Keywords: agricultural landscapes, solitary bees, connectivity, dispersal, field margins, habitat fragmentation, hedges, pollinators, predators, trap nests 


\section{Introduction}

Habitat loss and fragmentation are the main threats of biodiversity (Saunders et al. 1991, Fahrig 2003). Food specialists and species restricted by nesting requirements particularly suffer from the increasing fragmentation during the last decades because movements between habitat patches are disrupted (Rosenberg et al. 1997). Corridors consisting of small habitat strips between otherwise isolated habitat patches have been often proposed as a management strategy to enhance movements between habitats (Simberloff et al. 1992, Rosenberg et al. 1997, Beier \& Noss 1998). Thus, corridors may result in increased population sizes in habitat patches and prevent the extinction of small populations (Gonzalez et al. 1998).

Corridors can contribute to enhanced population sizes by facilitating movements between the connected habitat patches ("traditional corridor hypothesis") or by intercepting and directing individuals which move through the matrix ("drift fence hypothesis") (Haddad \& Baum 1999, Tewksbury et al. 2002, Fried et al. 2005, Levey et al. 2005). Evidence that corridors increase movement rates and population sizes exists for a number of species (reviewed in Beier \& Noss 1998, Aars \& Ims 1999, Tewksbury et al. 2002, Haddad et al. 2003, Fried et al. 2005, Haddad \& Tewksbury 2005). However, other studies did not find effects of corridors suggesting that results for single species do not allow generalizations (Haddad \& Baum 1999, Collinge 2000, Danielson \& Hubbard 2000). Corridors may even negatively affect species by increasing predation pressure or facilitating the spread of diseases (Hess 1994, Orrock et al. 2003, Orrock \& Damschen 2005).

In agricultural landscapes, noncrop habitat strips such as hedges and permanent grass strips provide habitat islands required by many farmland species as refuges, feeding and nesting areas (Stoate et al. 2001). A large part of these linear habitats have been lost in the course of agricultural intensification (Benton, Vickery \& Wilson 2003), when annual crops expanded at the cost of seminatural and non-intensively used noncrop habitats (Tilman et al. 2001, Benton, Vickery \& Wilson 2003). At the same time, the increase of agrochemical use and field sizes enhanced the inhospitality of the landscape matrix and with it the effective isolation of the remaining habitat fragments (Ricketts 2001, Baum et al. 2004). Working together, the loss of noncrop habitats and the 
increase of effective habitat isolation may have caused the serious decline of farmland biodiversity (Krebs et al. 1999).

Organisms in agricultural landscapes are adapted to a highly disturbed environment, which consists of a patchwork of habitats differing in their disturbance level. Multihabitat users such as bees and wasps relying on resources provided by different habitats (Westrich 1996) have to deal simultaneously with spatially separated and rapidly changing habitat patches. For them, movements do not only allow colonization of new habitat patches and exchanges between populations (Wiens et al. 1993), but are often necessary for the daily foraging in patches separated from the nesting habitat (Westrich 1996). In this way, multi-habitat users couple ecological processes such as pollination in various habitats at a landscape scale. Despite their relatively high mobility, particularly species that depend on resources distributed over larger scales are affected by habitat fragmentation (Steffan-Dewenter et al. 2002). Hudgens \& Haddad (2003) predicted that mainly species in changing landscapes and species adapted to the colonization of new habitats benefit from corridors.

Although corridors operate at landscape scales, replicated landscape experiments on corridor function are rare (Haddad \& Baum 1999, Tewksbury et al. 2002, Orrock et al. 2003, Baum et al. 2004, Fried et al. 2005, Levey et al. 2005, Orrock \& Damschen 2005, Townsend \& Levey 2005). Most corridor studies focus on sharp contrasts between corridor and matrix, for example cleared land surrounded by forest. Almost nothing is known about corridor-matrix-effects for openland habitats differing in quality, such as grassy strips surrounded by cropland. The difficulty in examining corridor function resulted in studies focusing on movement rates or population sizes of single species only. Conclusions drawn from those studies are difficult to generalize and to transfer to communities and ecological processes. Even when movement rates are enhanced, corridors may provide disadvantages by benefiting parasitoids and predators more than host and prey species. However, only little attention has been paid to effects of corridors on biotic interactions (Tewksbury et al. 2002, Orrock et al. 2003, Levey et al. 2005, Orrock \& Damschen 2005, Townsend \& Levey 2005). 
The purpose of our study was to assess corridor function for communities of aboveground nesting bees and wasps and their interactions with natural enemies. Both bee and wasp communities are known to be negatively affected by the reduction of habitat diversity and the loss of seminatural habitats in agricultural landscapes, because they depend on nesting sites provided by dead wood in noncrop habitats (Steffan-Dewenter 2003). In a large-scale experimental approach in agricultural landscapes, we established standardized nest patches to study how corridors influence colonization success of these two important groups of pollinators and pest antagonists. First, we tested the underlying hypothesis that forest edges serve as sources habitats for above-ground nesting bees and wasps. Second, we hypothesized that colonization of standardized nest patches benefits from corridors between source habitat and nest patches. Third, we hypothesized that corridors particularly benefited higher trophic levels, i.e. natural enemies of bees and wasps.

\section{Methods}

\section{Study landscapes and study sites}

The study was conducted in 2004 around Göttingen $\left(51.5^{\circ} \mathrm{N}, 9.9^{\circ} \mathrm{E}\right)$ in southern Lower Saxony, Germany. The region is characterised by intensively managed agricultural areas dominated by cereal fields, and patchily distributed fragments of forests and different semi-natural habitat fragments. Twelve spatially separated study landscapes were selected. Study landscapes were between 4 and $6 \mathrm{~km}^{2}$ in size, and between 1 and $30 \mathrm{~km}$ apart from each other. Within each study landscape, we established six nest patches consisting of standardized trap nests. Thus, we had 72 nest patches, but traps of four patches got lost during summer. Nest patches were situated in three habitat types: forest edges, hedges and grass strips. Forest edges bordered deciduous mixed forests dominated by Fagus sylvatica. In the forest edges, we placed trap nests $1 \mathrm{~m}$ from the outside stems at the grassy strip which separates the forest edge from a cereal field or intensively managed grassland. Hedges were at least $205 \mathrm{~m}$ long (mean \pm SE: $300.6 \pm$ $42.6 \mathrm{~m}, \mathrm{n}=24)$, paralleled a farm track and were not part of a hedge network. In hedges, trap nests were situated $1 \mathrm{~m}$ from the outside branches at the grassy strip between the hedge and the farm track. Grass strips were situated between a cereal field 
and a farm track, mostly included a narrow ditch, and had a naturally developed permanent layer, which were dominated by grass but showed also flowering herbs. Mean grass strip width was $2.8 \pm 0.1 \mathrm{~m}(\mathrm{SE})(\mathrm{n}=32)$ and trap nests were placed in the centre of the strip. In each study landscape, we compared a connected and an isolated hedge type (Table 1, Fig. 1): (1) "connected hedges": in hedges connected to the forest edge, trap nests were placed in the hedge $200 \mathrm{~m}$ apart from the forest edge, (2) "isolated hedges": in hedges isolated by agricultural fields by more than $600 \mathrm{~m}$ from the next forest edge, trap nests were placed in the hedge $200 \mathrm{~m}$ apart from one hedge end.

We sampled three types of grass strips per study landscape (Table 1, Fig. 1): (1) "connected grass strips": in grass strips directly connected to the forest edge, trap nests were placed in the grass strip $200 \mathrm{~m}$ apart from the forest edge, (2) "slightly isolated grass strips": trap nests were placed in grass strips paralleling the forest edge in a distance of $200 \mathrm{~m}$, separated from the forest edge by cereal fields, (3) "highly isolated grass strips": trap nests were placed in grass strips more than $600 \mathrm{~m}$ apart from the next forest edge.

Table 1: Investigated nest patch types (receiver patches) representing different combinations of habitat type, distance between nest patch and next nearby forest edge (source patch), corridor type and degree of isolation.

\begin{tabular}{lcccc}
\hline \hline habitat type & & $\begin{array}{c}\text { distance } \\
\text { source - receiver patch }\end{array}$ & $\begin{array}{c}\text { corridor type } \\
\text { source - nest patch }\end{array}$ & $\begin{array}{c}\text { connectivity/ } \\
\text { isolation }\end{array}$ \\
\hline (A) forest edge & $(\mathrm{n}=12)$ & $0 \mathrm{~m}$ & - & - \\
(B) hedgerow & $(\mathrm{n}=12)$ & $200 \mathrm{~m}$ & hedgerow & connected \\
(C) hedgerow & $(\mathrm{n}=12)$ & $>600 \mathrm{~m}$ & none & highly isolated \\
(D) grass strip & $(\mathrm{n}=11)$ & $200 \mathrm{~m}$ & grass strip & connected \\
(E) grass strip & $(\mathrm{n}=9)$ & $200 \mathrm{~m}$ & none (cereal field) & slightly isolated \\
(F) grass strip & $(\mathrm{n}=12)$ & $>600 \mathrm{~m}$ & none & highly isolated \\
\hline \hline
\end{tabular}

Note: Capitals in parentheses indicate trap nest locations shown in Fig. 1. The number of replicates for each combination of attributes is given in parentheses behind the habitat type. 


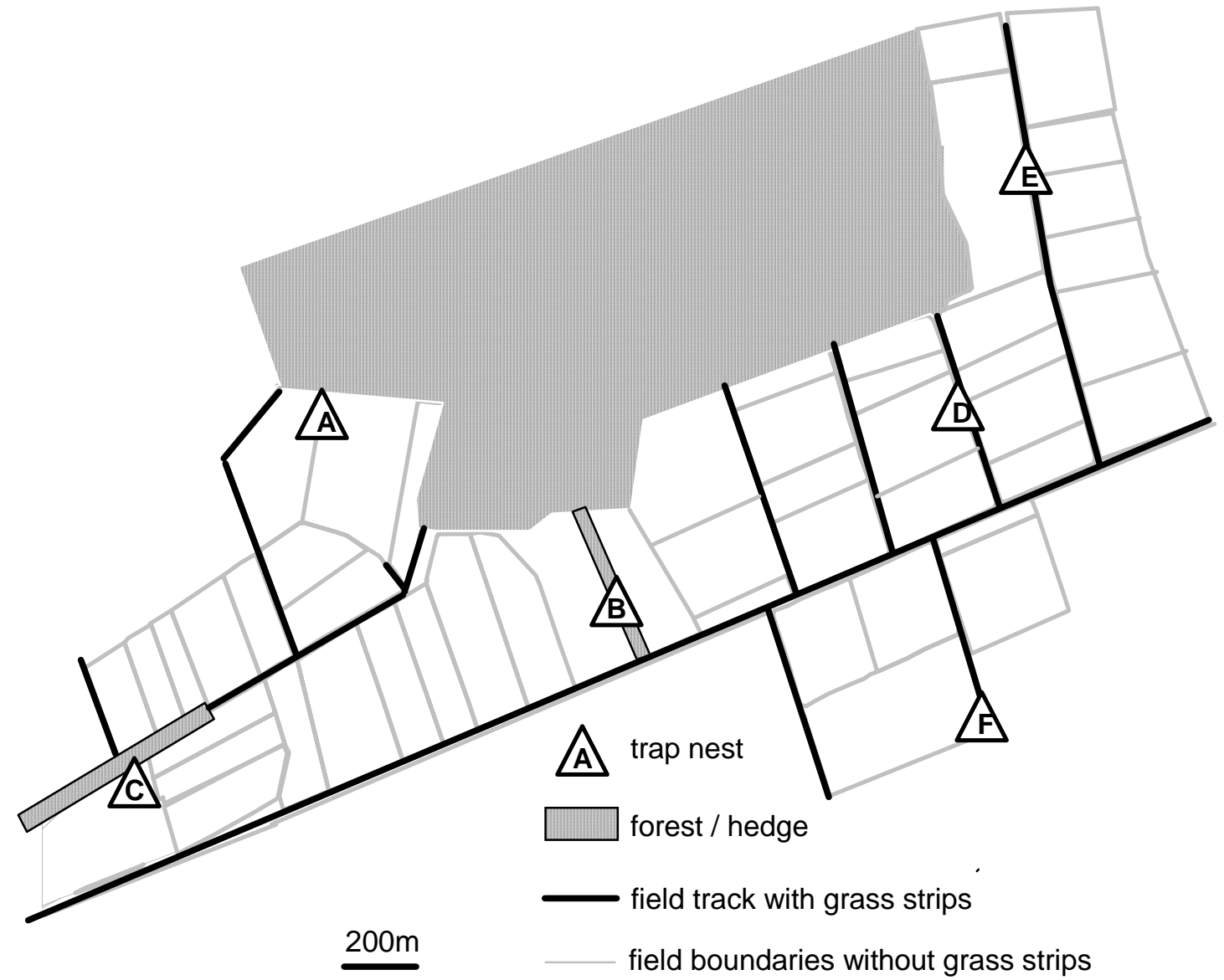

Fig. 1 Map of one of twelve study landscapes, illustrating the spatial arrangement of six nest patch treatments. The apexes of the triangles indicate the trap nest position. Trap nests were placed in a forest edge (A), in hedges $(B, C)$ and in grass strips (D-F). They were connected with a forest edge (B, D), slightly isolated $(200 \mathrm{~m})(\mathrm{E})$ or highly isolated $(>600 \mathrm{~m})(\mathrm{C}, \mathrm{F})$. Trap nests were at least $600 \mathrm{~m}$ apart from each other.

All grass strips were part of a grass strip network with a total length of several kilometres. Hedge lengths and grass strip width did not differ between connected and isolated hedges (ANOVA: $\mathrm{F}=0.70, \mathrm{P}>0.4)$ or grass strips $(\mathrm{ANOVA}: \mathrm{F}=0.36, \mathrm{P}>$ 0.6). Distances between trap nests and forest edges were chosen according to the homing range of trap-nesting bees which varied between 200 and $600 \mathrm{~m}$, depending on body size (Gathmann \& Tscharntke 2002). Distances between the 72 nest patches were at least $600 \mathrm{~m}$, thus we considered each nest patch as independent replicate. 


\section{Trap nest communities}

Trap nests enabled us to study species richness, abundance and interactions of aboveground nesting bees, wasps and their natural enemies under standardised nest site conditions (Tscharntke et al. 1998). In each of the 72 study locations, a wooden post was mounted fitted with four trap nest tubes for bees and wasps at a height of 1.0-1.2 m and shaded by a 41 x $50 \mathrm{~cm}$ chipboard roof. Each trap nest tube consisted of 150-180 $20 \mathrm{~cm}$ long internodes of common reed Phragmites australis, which were put into a $20 \mathrm{~cm}$ long, $10.5 \mathrm{~cm}$ diameter plastic tube. The diameters of reed internodes ranged from 2 to $10 \mathrm{~mm}$. The trap nests were in the field from mid-April until mid-September. In the laboratory, all reed internodes containing nests were opened. For each nest, the genus of bee or wasp larvae, the number of brood cells and the occurrence of natural enemies were recorded (Gathmann \& Tscharntke 1999). All nests were reared separately to get the adults of bees, wasps and their natural enemies for final species identification. Most larvae of bees, wasps and natural enemies were identified to the species level. In some cases, no adults emerged or all brood cells were parasitized, so that only the genus could be identified. These nests were included in the analyses as additional species if no other species of this genus were found at the same study site.

Species richness represented the total number of species, abundance the total number of brood cells of bees, wasps and natural enemies from four trap nests per study site. The mortality rate was the number of parasitized or predated brood cells divided by the total number of brood cells per study site. Data were separately analysed for four functional groups: predatory wasps (Sphecidae, Eumeninae, Pompilidae), bees (Apiformes), natural enemies of wasps and natural enemies of bees.

\section{Statistical Analyses}

We used linear mixed-effects models to determine effects of habitat types and the connectivity of trap nests and forest edges on bees and wasps and their natural enemies (Pinheiro \& Bates 2000). In all analyses, we grouped trap nests within study landscape by adding study landscape as random block factor. First, we tested for effects of the fixed factor "habitat type". The number of replicates was 12 for "forest edge", 24 for "hedge" and 32 for "grass strip" (see Table 1). 
Second, we analysed hedge and grass strip variants separately by including either "grass strip type" (comparison of connected, slightly isolated and highly isolated grass strips) or "hedge type" (comparison of connected and highly isolated hedges) as fixed factor (number of replicates see Table 1). Linear mixed-effect models were computed using the "Ime" function in the R-package "nlme" (R Development Core Team 2004).

Significant effects of the fixed factor revealed by Wald-type F-tests were further inspected using the contrasts between mean levels of the trap nest location types. The estimated contrasts were computed using the "estimable" function in the package "gregmisc". P-values of multiple comparisons were corrected using the Holm correction (Aickin \& Gensler 1996).

We transformed the number of species and the abundance of bees, wasps and natural enemies $(\log 10(\mathrm{x}+1))$ and the percentage values of the mortality rate (arcsine-squareroot-transformation) (Sokal \& Rohlf 1995).

\section{Results}

In total, 13952 brood cells of 14 wasp species (3284 brood cells) and 11 bee species (9324 brood cells of Osmia rufa, 1344 brood cells of other bee species) were collected from 72 nest patches (288 trap nest tubes). We recorded 17 species of natural enemies. Seven species of natural enemies attacked wasps, five species attacked bees and five species were found in both bee and wasp nests. The mean mortality by natural enemies was $31.0 \pm 3.6 \%$ (SE) for wasps, $33.9 \pm 3.7 \%$ (SE) for Osmia rufa and $10.6 \pm 3.3 \%$ (SE) for other bees.

\section{Wasps}

The number of brood cells and the species richness of wasps were significantly lower in grass strips than in forest edges (Table 2, Fig. 2). There was a trend towards less brood cells and species in hedges compared to forest edges, but the differences were marginally significant for the number of species only. Comparing grass strip types, abundance and species richness of wasps were lowest in highly isolated grass strips and highest in connected grass strips (Table 3, Fig. 3). Wasp abundance in connected grass 
strips was significantly higher than in slightly and highly isolated grass strips. Species richness in connected grass strips was significantly higher than in highly isolated grass strips, but did not differ significantly from species richness in slightly isolated grass strips. Slightly isolated and highly isolated grass strips did not significantly differ in wasp abundance and species richness. (Table 3, Fig. 3). There were no differences in wasp abundances and species richness between isolated and connected hedges (Table 4).

Table 2: Effects of habitat types (forest edge, hedge, grass strip) on species richness and number of brood cells of wasps, bees and their natural enemies.

\begin{tabular}{|c|c|c|c|c|c|c|c|}
\hline & & & \multicolumn{3}{|c|}{ Hosts } & \multicolumn{2}{|c|}{ Natural enemies } \\
\hline & & & $\mathrm{DF}$ & $\mathrm{F}$ & $\mathrm{P}^{*}$ & $\mathrm{~F}$ & $\mathrm{P}^{*}$ \\
\hline \multicolumn{8}{|c|}{ Wasps \& Natural enemies } \\
\hline \multirow[t]{2}{*}{ Species richness: } & Model & & 2,54 & 12.37 & $<0.001$ & 19.92 & $<0.001$ \\
\hline & $\begin{array}{l}\text { Forest edge } \\
\text { Forest edge } \\
\text { Hedge }\end{array}$ & $\begin{array}{l}>\text { Hedge } \dagger \\
>\text { Grass strip } \\
>\text { Grass strip }\end{array}$ & & & $\begin{aligned} & 0.098 \\
< & 0.001 \\
< & 0.001\end{aligned}$ & & $\begin{array}{r}0.014 \\
<0.001 \\
0.002\end{array}$ \\
\hline \multirow[t]{2}{*}{ Number of brood cells: } & Model & & 2,54 & 7.39 & 0.002 & 13.41 & $<0.001$ \\
\hline & $\begin{array}{l}\text { Forest edge } \\
\text { Forest edge } \\
\text { Hedge }\end{array}$ & $\begin{array}{l}>\text { Hedge } \\
>\text { Grass strip } \\
>\text { Grass strip }\end{array}$ & & & $\begin{array}{r}\mathrm{ns} \\
0.002 \\
0.030\end{array}$ & & $\begin{array}{r}0.014 \\
<0.001 \\
0.009\end{array}$ \\
\hline \multicolumn{8}{|l|}{ Bees \& Natural enemies } \\
\hline \multirow[t]{2}{*}{ Species richness: } & Model & & 2,54 & 2.83 & 0.068 & 5.05 & 0.010 \\
\hline & $\begin{array}{l}\text { Forest edge } \\
\text { Forest edge } \\
\text { Hedge }\end{array}$ & $\begin{array}{l}<\text { Hedge } \\
<\text { Grass strip } \\
>\text { Grass strip }\end{array}$ & & & $\begin{array}{r}0.063 \\
\mathrm{~ns} \\
\mathrm{~ns}\end{array}$ & & $\begin{array}{r}0.014 \\
0.014 \\
\mathrm{~ns}\end{array}$ \\
\hline \multirow[t]{2}{*}{ Number of brood cells: } & Model & & 2,54 & 5.02 & 0.010 & 3.85 & 0.027 \\
\hline & $\begin{array}{l}\text { Forest edge } \\
\text { Forest edge } \\
\text { Hedge }\end{array}$ & $\begin{array}{l}<\text { Hedge } \\
<\text { Grass strip } \\
<\text { Grass strip }\end{array}$ & & & $\begin{array}{r}0.046 \\
0.008 \\
\text { ns }\end{array}$ & & $\begin{array}{r}0.041 \\
0.029 \\
\mathrm{~ns}\end{array}$ \\
\hline
\end{tabular}

Note: Degrees of freedom, F- and P-values from linear mixed-effects models including habitat type as fixed factor and study landscape as random block factor are shown.

* P-values of multiple comparisons were corrected using the Holm correction. P-values are shown when $<0.1$.

$\dagger$ Trends of differences between grass strip types are indicated with $<$ and $>$. 

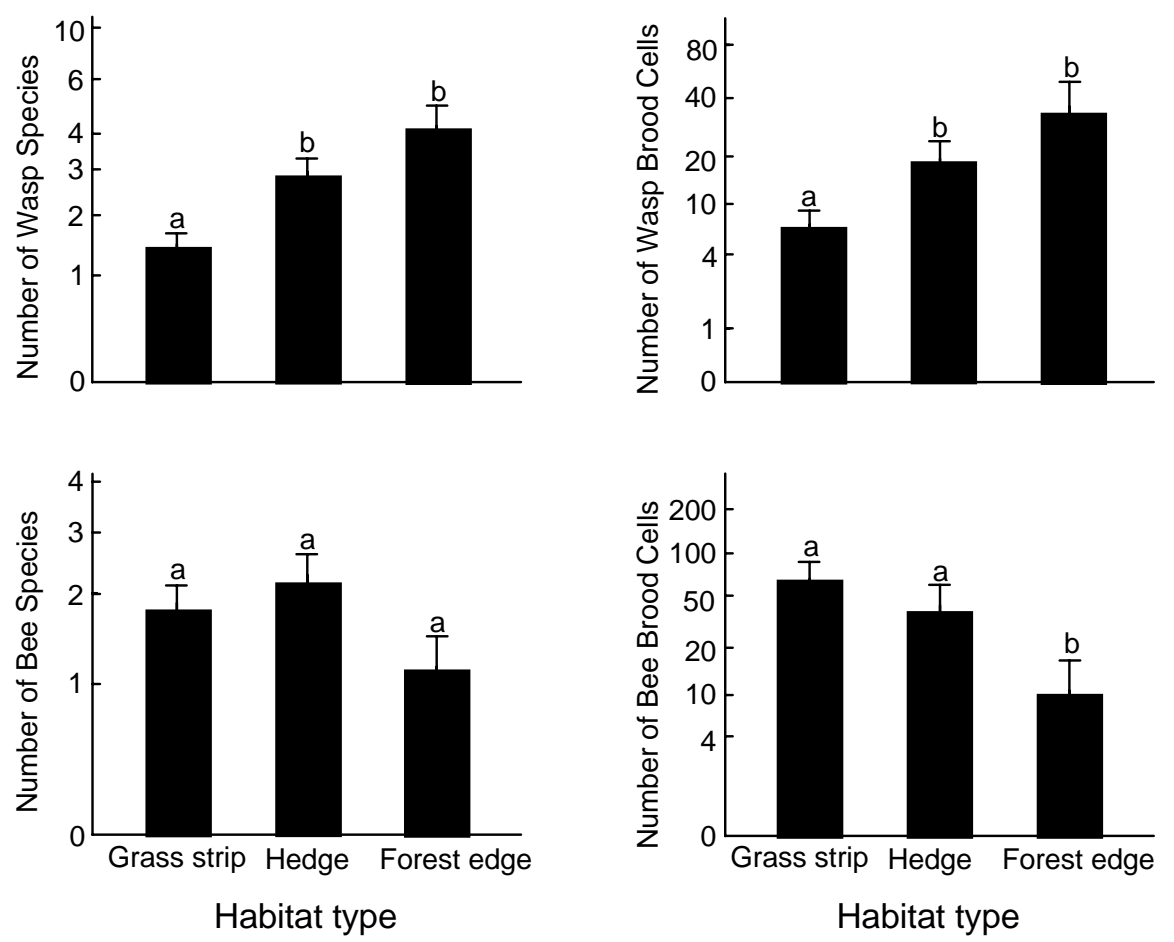

Fig. 2 Effects of habitat types on species richness and number of brood cells of bees and wasps. Results are from linear mixed-effects models (Table 2). Means and standard errors are shown. Different letters indicate significant differences (Holm corrected $\mathrm{P}<0.05)$.

\section{Bees}

Bee species richness did not differ between habitat types, but the number of brood cells was significantly lower in forest edges than in hedges or grass strips (Table 2, Fig. 2). Analysing brood cells of Osmia rufa and other bees separately, we found the same pattern for Osmia rufa brood cells as for total bee brood cells, but the difference between hedges and forest edges was marginally significant only. Brood cell numbers of other bees were not influenced by the habitat type. Thus, we had to refute the underlying hypothesis that forest edges serve as source habitats for trap-nesting bees. Corresponding to that, the position of hedges or grass strips in relation to a forest edge did not affect species richness and number of brood cells of bees (Tables $3 \& 4$, Fig. 3). 
Table 3: Species richness and number of brood cells of wasps, bees and their natural enemies in nest patches in connected, slightly and highly isolated grass strips.

\begin{tabular}{|c|c|c|c|c|c|c|c|}
\hline & & & \multicolumn{3}{|c|}{ Hosts } & \multicolumn{2}{|c|}{ Natural enemies } \\
\hline & & & $\mathrm{DF}$ & $\mathrm{F}$ & $\mathrm{P} *$ & $\mathrm{~F}$ & $\mathrm{P}^{*}$ \\
\hline \multicolumn{8}{|c|}{ Wasps \& Natural enemies } \\
\hline \multirow[t]{2}{*}{ Species richness: } & Model & & 2,18 & 4.62 & 0.024 & 1.52 & ns \\
\hline & $\begin{array}{l}\text { highly } \\
\text { isolated } \\
\text { highly } \\
\text { isolated } \\
\text { slightly } \\
\text { isolated }\end{array}$ & $\begin{array}{l}<\text { connected } \\
<\begin{array}{l}\text { slightly } \\
\text { isolated }\end{array} \\
<\text { connected }\end{array}$ & & & $\begin{array}{r}0.021 \\
\text { ns } \\
\text { ns }\end{array}$ & & \\
\hline \multirow[t]{2}{*}{ Number of brood cells: } & Model & & 2,18 & 8.43 & 0.003 & 1.67 & ns \\
\hline & $\begin{array}{l}\text { highly } \\
\text { isolated } \\
\text { highly } \\
\text { isolated } \\
\text { slightly } \\
\text { isolated }\end{array}$ & $\begin{array}{l}<\text { connected } \\
<\begin{array}{l}\text { slightly } \\
\text { isolated }\end{array} \\
<\text { connected }\end{array}$ & & & $\begin{array}{r}0.003 \\
\text { ns } \\
0.017\end{array}$ & & \\
\hline \multicolumn{8}{|l|}{ Bees \& Natural enemies } \\
\hline Species richness: & Model & & 2,18 & 1.55 & ns & 1.16 & ns \\
\hline Number of brood cells: & Model & & 2,18 & 2.36 & ns & 0.96 & ns \\
\hline
\end{tabular}

Note: Degrees of freedom, F- and P-values from linear mixed-effects models including habitat type as fixed factor and study landscape as random block factor are shown.

* P-values of multiple comparisons were corrected using the Holm correction. P-values are shown when

$<0.1$. Trends of differences between grass strip types are indicated with $<$ and $>$.

Table 4: Species richness and number of brood cells of wasps, bees and their natural enemies in connected and unconnected nest patches in hedges.

\begin{tabular}{lccccc}
\hline & & \multicolumn{2}{c}{ Hosts } & \multicolumn{2}{c}{ Natural enemies } \\
\hline & $\mathrm{DF}$ & $\mathrm{F}$ & $\mathrm{P}$ & $\mathrm{F}$ & $\mathrm{P}$ \\
\hline Wasps \& Natural enemies & & & & & \\
Species richness: & 1,10 & 1.67 & $\mathrm{~ns}$ & 0.72 & $\mathrm{~ns}$ \\
Number of brood cells: & 1,10 & 0.27 & $\mathrm{~ns}$ & $<0.01$ & $\mathrm{~ns}$ \\
Bees \& Natural enemies & & & & & $\mathrm{ns}$ \\
Species richness: & 1,10 & 0.97 & $\mathrm{~ns}$ & 0.20 & $\mathrm{~ns}$ \\
Number of brood cells: & 1,10 & 1.05 & $\mathrm{~ns}$ & 2.61 & \\
\hline \hline
\end{tabular}

Note: Degrees of freedom, F- and P-values from linear mixed-effects models including habitat type as fixed factor and study landscape as random block factor are shown. 


\section{Natural enemies of wasps}

Species richness and abundance of natural wasp enemies were higher in forest edges than in hedges, and higher in hedges than in grass strips (Table 2). The connectivity of hedges or grass strips in relation to a forest edge did not significantly influence the species richness or abundance of natural wasp enemies (Table $3 \& 4$ ). Accordingly, we did not find any effects of habitat type, forest edge vicinity or corridors on the mortality of wasps due to natural enemies ( $\mathrm{P}>0.1$ in all cases). Thus, the number of surviving wasp larvae in the three habitat types showed the same pattern as the total number of wasp brood cells.
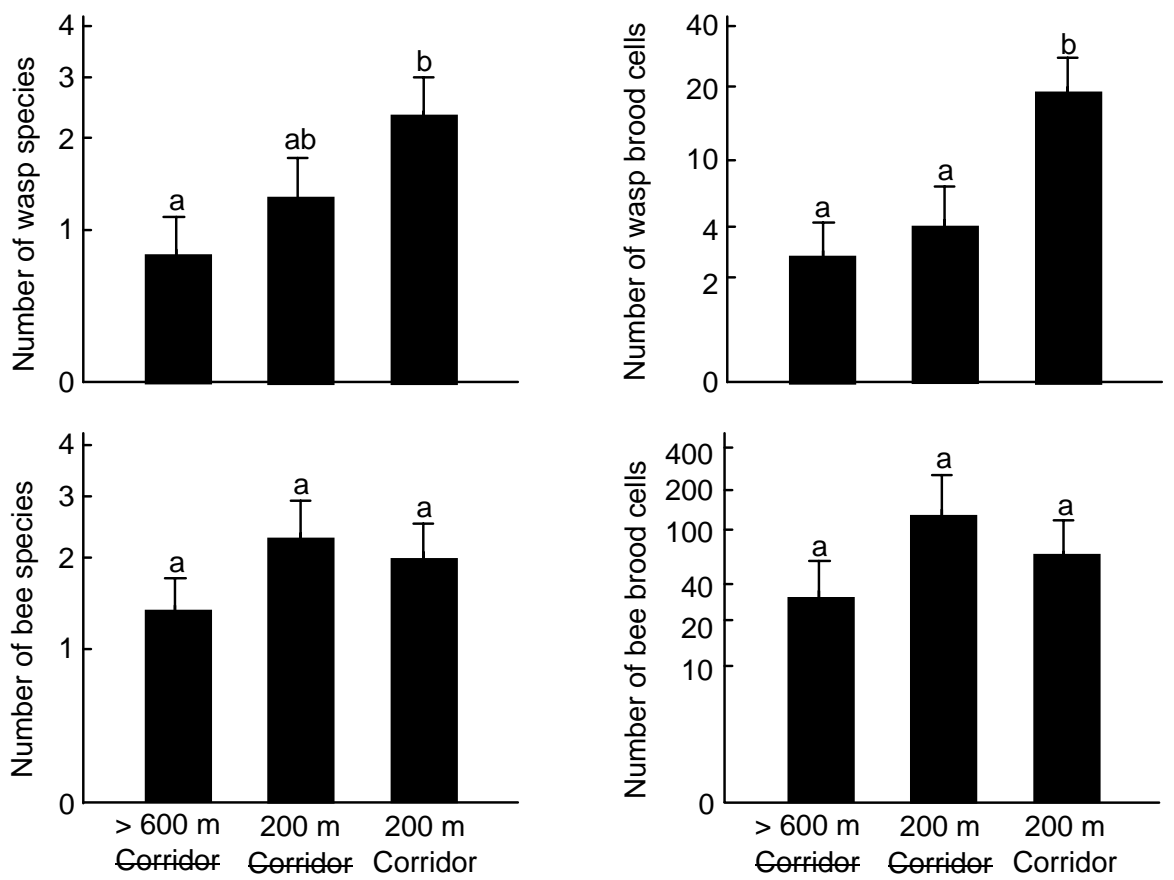

Nest Patch - Forest Connectivity

Nest Patch - Forest Connectivity

Fig. 3 Effects of connectivity on the species richness and number of brood cells of bees and wasps in grass strips. Trap nests were highly isolated from a forest edge ( $>600 \mathrm{~m}$, no corridor), slightly isolated (200 m, no corridor) or connected with a forest edge (200 m, grass strip corridor). Results are from linear mixed-effects models (Table 3). Means and standard errors are shown. Different letters indicate significant differences (Holm corrected $\mathrm{P}<0.05$ ). 


\section{Natural enemies of bees}

Species richness and abundance of natural bee enemies were significantly lower in forest edges than in hedges or grass strips (Table 2). There were no significant differences between hedges and grass strips. We found the same pattern for the abundance of natural enemies in nests of Osmia rufa. The abundance of natural enemies in nests of other bees did not depend on the habitat type. Natural bee enemies were not influenced by the position of hedges or grass strips in relation to a forest edge.

The mortality rates of all bees due to natural enemies did not differ between habitat types, but the mortality rates of Osmia rufa were significantly lower in grass strips than in hedges (linear mixed-effects model with habitat type as fixed factor: $\mathrm{F}=5.5, \mathrm{P}=$ 0.008 , post-hoc comparison grass strip - hedge: Holm-corrected $\mathrm{P}=0.007)$. Thus, the number of surviving Osmia rufa larvae was marginally significantly higher in grass strips than in hedges (post-hoc comparison grass strip - hedge: Holm-corrected $\mathrm{P}=$ 0.063), although the total number of Osmia rufa brood cells did not differ between both habitat types (post-hoc comparison grass strip - hedge: Holm-corrected $\mathrm{P}=0.182$ ). The mortality rate of Osmia rufa in forest edges did not significantly differ from mortality rates in grass strips or hedges (post-hoc comparisons: $\mathrm{P}>0.1$ ).

\section{Discussion}

Our experimental corridor study was based on the hypothesis that above-ground nesting bees and wasps are more abundant and diverse in forest edges than in hedges or grass strips. With forest edges serving as source habitats, we tested the hypothesis that species richness and the abundance of bees and wasps are higher in newly established nest patches that are connected with the source habitat by a corridor than in unconnected patches or in patches without potential colonization source nearby.

For bees, the underlying hypothesis had to be rejected, because species richness did not differ between the three habitat types. The number of brood cells was even lower in forest edges than in hedges and grass strips. Forest edges did obviously not act as source habitats for bees. Thus, our study design did not enable us to test the hypothesis that corridors facilitate movements of bees between forest edges and nest patches. 
Corresponding to that, bees did not respond to the vicinity of a forest edge or to the occurrence of a corridor connecting new nest sites and forest edges.

Nesting sites of above-ground nesting bees and wasps are provided by hollow stems and holes in dead wood (Tscharntke et al. 1998). In agricultural landscapes, nesting sites are restricted to forest edges, hedges and old trees. Grass strips normally do not provide nesting habitats. We expected forest edges to show the highest species richness and number of brood cells, because above-ground nesting bees and wasps benefit from a large area of their nesting habitat (Steffan-Dewenter 2003). However, our results show lower bee abundances in forest edges. A reason may be that open agricultural landscapes provided more flower resources during spring and summer, i.e. when these bees forage, than forest edges where trees and shrubs mainly flower in spring.

For wasps, species richness and numbers of brood cells were higher in forest edges than in grass strips. Our result supports the hypothesis that forest edges can serve as source patches for wasps. However, forest edges did not differ from hedges in wasp species richness or the number of brood cells. This is consistent with our result that wasps in hedges were not influenced by the vicinity of a forest. Apparently, hedges are selfsustained habitats which do not depend in short-terms on colonization from another source patch. The low species richness and number of brood cells in grass strips, especially in the absence of a nearby forest edge, support that grass strips do not sustain own wasp populations and nest patches in grass strips depend on colonization from source habitats.

Grass strip corridors clearly facilitated movements of wasps in agricultural landscapes. The mean number of brood cells in grass strips connecting trap nests and source habitats was more than four times higher than in grass strips paralleling source habitats or in grass strips without source habitat nearby. Our results support the traditional corridor hypothesis that corridors facilitate movements of organisms by directing movements from one habitat patch (forest edge) into an otherwise isolated habitat patch (standardized nest patch). We reject the drift fence hypothesis, which states that corridors direct organisms from the matrix into a habitat patch (Haddad \& Baum 1999, Tewksbury et al. 2002, Fried et al. 2005, Levey et al. 2005), because the probability that grass strips intercept organisms moving through the matrix should have been highest in grass strips paralleling a source habitat. 
The majority of studies on corridor function is not spatially replicated or based on movement observations, and results are therefore difficult to interpret (reviewed in Beier and Noss 1998, Debinski and Holt 2000). Studies based on replicated field experiments focus on corridor effects at very small-scales (La Polla \& Barrett 1993, Collinge 2000) or are performed at landscape scales, but in artificial landscapes consisting of only one habitat type within a non-habitat matrix (Haddad 1999, Haddad \& Baum 1999, Tewksbury et al. 2002, Haddad et al. 2003, Orrock et al. 2003, Baum et al. 2004, Levey et al. 2005, Orrock \& Damschen 2005, Fried et al. 2005, Haddad \& Tewskbury, 2005, Levey et al. 2005, Townsend \& Levey 2005). Both approaches are not applicable when examining mobile multi-habitat users in agricultural mosaic landscapes.

Wasps perceived source habitats and standardized nest sites separated by a cereal field as isolated although they may visit fields for foraging. Other studies suggest that the effective isolation and the positive influence of corridors on movements increase with increasing degree of matrix inhospitality (Ricketts 2001, Hudgens \& Haddad 2003, Baum et al. 2004). Corridors are most effective when the matrix is non-permeable. However, corridors can have positive effects on individuals even when some individuals move through the matrix as they may facilitate orientation and reduce losses during travelling (Hudgens \& Haddad 2003). We conclude that the loss of edge structures may have contributed to the decline of predators in agricultural landscapes by interrupting movements and colonization processes.

Nest patches connected by corridors may serve as stepping stones benefiting further colonization processes and population viability. High short-term colonization rates may not be related to high population viability in either case, because also unconnected nest patches may be colonized over the longer term and have similar species richness and abundance as connected patches (Beier \& Noss 1998). However, in landscapes with highly limited nesting sites and annually changing crops and food availability, rapid colonization of nest patches may be linked to high overall population viability.

Corridors may enhance movements between habitat patches even when the habitat forming the corridor is unsuitable to support resident populations (Haddad \& Tewksbury 2005). This is supported by our finding that grass strips served as movement conduits although they are unsuitable for the reproduction of above-ground nesting 
wasps. By contrast, hedges may be self-sustained habitats providing nesting sites and food for both bees and wasps. Wasp species richness and the number of brood cells did not differ between hedges and forest edges supporting the high conservation value of hedges in agricultural landscapes (Burel 1996). We could not examine whether hedges facilitate movements of wasps, because there were no differences between forest edges and hedges, and the vicinity of a forest apparently did not provide an additional benefit for wasps in hedges.

We did not find higher mortality rates of bees or wasps in connected receiver patches than in unconnected patches. Mortality rates may be increased in connected patches if natural enemies depend more on corridors than their hosts (Hess 1994, Orrock et al. 2003, Orrock \& Damschen 2005). There is some evidence that higher trophic levels suffer more from habitat isolation than their hosts (Kruess \& Tscharntke 1994, Thies \& Tscharntke 1999). Higher trophic levels have lower abundances and are more dependent on recolonization processes, because they are more affected by frequent disturbances and local population extinctions (Holt 2002). Furthermore, natural enemies may have more restrictive dispersal abilities and perceive isolation at smaller scales than their hosts (van Nouhuys \& Hanski 2002). According to our data, natural enemies were more strongly influenced by the habitat type than their hosts, but corridors formed by hedges and grass strips did not enhance movements of natural enemies between habitat patches. However, the low colonization of nest patches in grass strips by natural enemies even resulted in a lower mortality rate of Osmia rufa in grass strips than in hedges.

Our results suggest that forest edges and hedges are required as nesting habitats for above-ground nesting wasps in agricultural landscapes. However, the colonization of standardized nests in grass strips by bees and wasps shows that even single old trees or shrubs may provide valuable nesting sites if they are connected to source habitats. Grass strips providing connectivity improved the colonization of nest patches by wasps. Accordingly, a landscape management strategy that increases the availability of connected nest sites could improve biological control by wasps in neighbouring crop habitats. 


\section{References}

Aars, J. \& Ims, R.A. (1999) The effect of habitat corridors on rates of transfer and interbreeding between vole demes. Ecology, 80, 1648-1655.

Aickin, M. \& Gensler, H. (1996) Adjusting for multiple testing when reporting research results: the Bonferroni vs holm methods. American Journal of Public Health, 86, 726-728.

Baum, K.A., Haynes, K.J., Dillemuth, F.P., \& Cronin, J.T. (2004) The matrix enhances the effectiveness of corridors and stepping stones. Ecology, 85, 2671-2676.

Beier, P. \& Noss, R.F. (1998) Do habitat corridors provide connectivity? Conservation Biology 12, 1241-1252.

Benton, T.G., Vickery, J.A., \& Wilson, J.D. (2003) Farmland biodiversity: is habitat heterogeneity the key? Trends in Ecology and Evolution, 18, 182-188.

Burel, F. (1996) Hedgerows and their role in agricultural landscapes. Critical Reviews in Plant Sciences, 15, 169-190

Collinge, S.K. (2000) Effects of grassland fragmentation on insect species loss, colonization, and movement patterns. Ecology, 81, 2211-2226.

Danielson, B.J. \& Hubbard, M.W. (2000) The influence of corridors on the movement behavior of individual Peromyscus polionotus in experimental landscapes. Landscape Ecology, 15, 323-331.

Debinski, D.M. \& Holt, R. D. (2000) A survey and overview of habitat fragmentation experiments. Conservation Biology, 14, 342-355.

Fahrig, L. (2003) Effects of habitat fragmentation on biodiversity. Annual Review of Ecology Evolution and Systematics, 34, 487-515.

Fried J.H., Levey D.J. \& Hogsette J. (2005) Habitat corridors function as both drift fences and movement conduits for dispersing flies. Oecologia, 143, 645-651.

Gathmann, A. \& Tscharntke, T. (2002) Foraging ranges of solitary bees. Journal of Animal Ecology, 71, $757-764$

Gathmann, A. \& Tscharntke, T. (1999) Landschafts-Bewertung mit Bienen und Wespen in Nisthilfen: Artenspektrum, Interaktionen und Bestimmungsschlüssel. Naturschutz und Landschaftspflege in Baden-Württemberg, 73, 277-305. 
Gonzalez, A., Lawton, J.H., Gilbert, F.S., Blackburn, T.M., \& Evans-Freke, I. (1998) Metapopulation dynamics, abundance, and distribution in a microecosystem. Science, 281, 2045-2047.

Haddad, N.M. (1999) Corridor and distance effects on interpatch movements: a landscape experiment with butterflies. Ecological Applications, 9, 612-622.

Haddad, N.M. \& Baum, K.A. (1999) An experimental test of corridor effects on butterfly densities. Ecological Applications, 9, 623-633.

Haddad, N.M., Bowne, D.R., Cunningham, A., Danielson, B.J., Levey, D.J., Sargent, S., \& Spira, T. (2003) Corridor use by diverse taxa. Ecology, 84, 609-615.

Haddad, N.M. \& Tewksbury, J.J. (2005) Low-quality habitat corridors as movement conduits for two butterfly species. Ecological Applications, 15, 250-257.

Hess, G.R. (1994) Conservation corridors and contagious disease - a cautionary note. Conservation Biology, 8, 256-262.

Holt R.D. (2002) Food webs in space: On the interplay of dynamic instability and spatial processes. Ecological Research, 17, 261-273.

Hudgens, B.R. \& Haddad, N.M. (2003) Predicting which species will benefit from corridors in fragmented landscapes from population growth models. American Naturalist, 161, 808-820.

Krebs, J.R., Wilson, J.D., Bradbury, R.B., \& Siriwardena, G.M. (1999) The second silent spring. Nature, 400, 611-612.

Kruess, A. \& Tscharntke, T. (1994) Habitat fragmentation, species loss, and biological control. Science, 264, 1581-1584.

La Polla, V.N. \& Barrett, G. W. (1993) Effects of corridor width and presence on the populationdynamics of the meadow vole (Microtus pennsylvanicus). Landscape Ecology, 8, 25-37.

Levey, D.J., Bolker, B.M., Tewksbury, J.J., Sargent, S., \& Haddad, N.M. (2005) Effects of landscape corridors on seed dispersal by birds. Science, 309, 146-148.

Orrock, J.L. \& Damschen, E.I. (2005) Corridors cause differential seed predation. Ecological Applications, 15, 793-798.

Orrock, J.L., Danielson, B.J., Burns, M.J., \& Levey, D.J. (2003) Spatial ecology of predator-prey interactions: corridors and patch shape influence seed predation. Ecology, 84, 2589-2599. 
Pinheiro, J.B. \& Bates, D.M. (2000) Mixed-effects models in S and S-Plus. Springer, New York.

Ricketts, T.H. (2001) The matrix matters: effective isolation in fragmented landscapes. American Naturalist, 158, 87-99.

Rosenberg, D.K., Noon, B.R., \& Meslow, E.C. (1997) Biological corridors: form, function, and efficacy. Bioscience, 47, 677-687.

Saunders, D.A., Hobbs, R.J., \& Margules, C.R. (1991) Biological consequences of ecosystem fragmentation - a review. Conservation Biology, 5, 18-32.

Simberloff, D., Farr, J.A., Cox, J., \& Mehlman, D.W. (1992) Movement corridors - conservation bargains or poor investments. Conservation Biology, 6, 493-504.

Sokal, R.R. \& Rohlf, F.J. (1995) Biometry: the principles and practice of statistics in biological research. $3^{\text {rd }}$ edn. Freeman, New York.

Steffan-Dewenter, I. (2003) The importance of habitat area and landscape context for species richness of bees and wasps in fragmented orchard meadows. Conservation Biology, 17, 1036-1044.

Steffan-Dewenter, I., Münzenberg, U., Bürger, C., Thies, C., \& Tscharntke, T. (2002) Scale-dependent effects of landscape context on three pollinator guilds. Ecology, 83, 1421-1432.

Stoate, C., Boatman, N.D., Borralho, R.J., Carvalho, C.R., de Snoo, G.R., \& Eden, P. (2001) Ecological impacts of arable intensification in Europe. Journal of Environmental Management, 63, 337-365.

Tewksbury, J.J., Levey, D.J., Haddad, N.M., Sargent, S., Orrock, J.L., Weldon, A., Danielson, B.J., Brinkerhoff, J., Damschen, E.I., \& Townsend, P. (2002) Corridors affect plants, animals, and their interactions in fragmented landscapes. Proceedings of the National Academy of Sciences of the United States of America, 99, 12923-12926.

Thies, C. \& Tscharntke, T. (1999) Landscape structure and biological control in agroecosystems. Science, 285, 893-895.

Tilman, D., Fargione, J., Wolff, B., D'Antonio, C., Dobson, A., Howarth, R., Schindler, D., Schlesinger, W.H., Simberloff, D., \& Swackhamer, D. (2001) Forecasting agriculturally driven global environmental change. Science, 292, 281-284.

Townsend, P.A. \& Levey, D.J. (2005) An experimental test of whether habitat corridors affect pollen transfer. Ecology, 86, 466-475. 
Tscharntke, T., Gathmann, A., \& Steffan-Dewenter, I. (1998) Bioindication using trap-nesting bees, wasps and parasitoids: community structure and interactions. Journal of Applied Ecology, 35, 708-719.

van Nouhuys S. \& Hanski I. (2002) Colonization rates and distances of a host butterfly and two specific parasitoids in a fragmented landscape. Journal of Animal Ecology, 71, 639-650.

Westrich, P. (1996) Habitat requirements of central European bees and the problems of partial habitats. Pages 1-16 in A. Matheson, S.L. Buchmann, C.O’Toole, P.Westrich and I.H. Westrich, editors. The conservation of bees. Academic press, London, UK.

Wiens, J.A., Stenseth, N.C., Vanhorne, B., \& Ims, R.A. (1993) Ecological Mechanisms and Landscape Ecology. Oikos, 66, 369-380. 


\section{Summary}

Agricultural landscapes are characterized by close interactions between annually ploughed crop fields and relatively little disturbed noncrop areas. Many species have adapted to these mosaic landscapes and species-rich agroecosystems developed as a result of moderate anthropogenic changes. During the last decades, agricultural intensification has caused a rapid decline of biodiversity in agroecosystems. Intensive farming practices with high agrochemical inputs displaced low-intensity farming, crop fields expanded at the cost of noncrop habitats, and hedgerows and fallow strips were removed in the course of field enlargement. These substantial changes in land-use intensity threat biodiversity and may disrupt trophic interactions and ecosystem services.

In this study, we investigated how organic farming, landscape complexity and dispersal corridors may contribute to the diversity of bees and wasps in agroecosystems. Further, we examined how interactions with natural enemies were influenced. Our investigations were conducted in agricultural landscapes in the vicinity of the city of Göttingen, the Soester Börde and the Lahn-Dill-Bergland. Landscapes were selected to encompass a gradient from homogeneous crop-dominated landscapes to heterogeneous landscapes dominated by a diversity of noncrop habitats. Bees, wasps and their natural enemies were recorded in altogether 74 organic and conventional wheat fields, 74 fallow strips, 32 grass strip corridors, 24 hedges and 12 forest edges.

Diversity of flower-visiting bees in wheat fields was greatly enhanced by organic farming due to a higher availability of flowering noncrop plants in organic compared to conventional fields. Differences in bee diversity between organic and conventional fields increased with the proportion of crop fields in the surrounding landscape $(1 \mathrm{~km}$ radius), thereby indicating that processes at the landscape level have the potential to modify the effectiveness of agri-environment schemes. Organic farming in homogeneous landscapes with few remaining flower-rich habitats may reach highest relative effectiveness. 
Bee communities in fallow strips were influenced by organic crop fields at a local and a landscape scale. At the local scale, species richness of bees and abundance of solitary and bumble bees were higher in fallow strips adjacent to organic than to conventional fields. At the landscape scale, species richness and abundances of bees were enhanced by a high proportion of organic crop fields in the surrounding landscape. An increase of the proportion of organic crop fields from now $4.4 \%$ on average in Germany to $20 \%$ as aimed by the government may enhance species richness of bees in fallow strips by 54 $\%$, density of solitary bees by $66 \%$ and bumble bee density by $156 \%$.

Nest colonization of cavity-nesting bees and wasps was enhanced by heterogeneous landscapes, organic farming and fallow strips. Wasps benefited more from fallow strips than from organic compared to conventional farming. Wasps in fallow strips were not influenced by the farming system of the adjacent field. This suggests that wasps preferred dispersing along fallow strips and that wasps nesting in fallow strips did not substantially utilize resources provided by the adjacent field. The positive effect of fallow strips at the local scale was consistent with a positive effect of high edge densities providing dispersal structures at a landscape scale. In contrast, bee colonization was enhanced by organic farming in both field centres and adjacent fallow strips, which did not significantly differ in bee abundance. This suggests that bees nesting in noncrop habitats benefited from resources in neighbouring organic wheat fields and did not depend on noncrop habitats for foraging or dispersal. A positive effect of high proportions of noncrop habitats in the surrounding landscape underlined that nest colonization of bees was influenced by source habitats.

Grass strip corridors connecting forest edges (source habitats) and standardized nesting sites in cropland landscapes enhanced the abundance of solitary wasps in nest patches by $400 \%$ compared to isolated nest patches. Natural enemies largely reflected the patterns found for their hosts, and mortality due to natural enemies did not depend on the presence of a corridor. In agricultural landscapes, where nesting sites are limited and food availability changes frequently, rapid colonization of nest patches may be linked to high population viability. 
In conclusion, local and large-scale land-use intensity influenced diversity of bees and wasps in agroecosystems, because cross-habitat fluxes at a landscape scale connected crop fields providing foraging resources and noncrop habitats providing nesting sites. Conservation management plans and studies assessing biodiversity patterns have to consider factors at both local and landscape scales, because they have the potential to modify or to complement effects of each other. Organic farming may help that crosshabitat fluxes enhance communities and ecosystem services in both crop and noncrop habitats, but noncrop habitats providing nesting sites and connectivity for wasp movements are required to maintain bee and wasp populations in agroecosystems. 


\section{Danksagung}

Sehr herzlich danke ich Prof. Dr. Teja Tscharntke für die Bereitstellung des Themas, die unzähligen Anregungen und die hervorragende Betreuung und Unterstützung während meiner gesamten Promotionszeit.

Bei Prof. Dr. Matthias Schaefer bedanke ich mich für die freundliche Übernahme des Korreferats.

Besonders dankbar bin ich PD Dr. Ingolf Steffan-Dewenter, dass er mir mit vielen guten Ideen weitergeholfen hat und dass er sich für alle Fragen und Probleme immer Zeit nahm und Antworten und Lösungen wusste. Ganz herzlichen Dank für die schöne Zusammenarbeit!

Dr. David Kleijn hat das EASY-Projekt und damit meine Arbeit erst möglich gemacht. Sehr bedanken möchte ich mich bei ihm für die großartige Koordination des Projekts. Herzlichen Dank an ihn und all die anderen EASY-Leute für viele Diskussionen und Anregungen und sehr viel Spaß, der die Projekttreffen unvergesslich gemacht hat.

Yann möchte ich besonders danken für die sehr angenehme Zusammenarbeit im EASYProjekt von der Vorbereitung der Freilandarbeit und den unzähligen Stunden auf der Autobahn bis zum Auswerten und Publizieren der Daten. Mit unerschöpflichem Statistikwissen und gegoogelten Antworten auf alle Lebensfragen war er mir eine riesige Hilfe. Danke dafür!

Hella Grabe und Susanne Schiele haben zum Glück immer den Überblick bewahrt und viele Probleme aus dem Weg geschafft, bevor wir sie überhaupt bemerkt haben. Herzlichen Dank, dass ihr alles am Laufen gehalten habt!

Dr. Tobias Purtauf danke ich für seine Unterstützung bei der Flächenauswahl und Dr. Doreen Gabriel, dass sie mir mit Rat und Tat bei der GIS-Analyse zur Seite gestanden hat. 
Stéphanie und Schirin bin ich sehr dankbar, dass sie unzählige GIS-Karten mühevoll digitalisiert haben.

Viele Helfer haben an über 1000 Nisthilfen mitgebastelt, ihnen allen und ganz besonders Manuel, Martin, Bernhard, Tim und Arno ganz vielen Dank.

Besonders bedanken möchte ich mich bei Anne und Gundula, die sich in das Geheimnis des Nisthilfeninhalts eingearbeitet haben und mir sehr bei der Auswertung geholfen haben.

Dr. Reiner Theunert danke ich sehr, dass er sich bereiterklärt hat, einige meiner Bienen nachzubestimmen.

Ein ganz besonderes Dankeschön an über 50 Landwirte, die uns auf ihre Felder gelassen haben, um Nisthilfen herum gewirtschaftet haben und endlose Fragebögen beantwortet haben.

Mein herzlicher Dank gilt Ines, Arno, Birgit und Yann, die mir sehr liebe Zimmergenossen waren und die immer für eine angenehme Arbeitsatmosphäre gesorgt haben.

Vielen lieben Dank an alle Mitarbeiterinnen und Mitarbeiter des Fachgebiets Agrarökologie für ihre Aufgeschlossenheit und Hilfsbereitschaft und ihren Beitrag dazu, dass meine Zeit in der Arbeitsgruppe wunderschön war!

Und tausend Dank an meine Eltern und Mex für ihre Liebe, ihr Verständnis und ihre tatkräftige Unterstützung! 


\section{Publikationen}

Holzschuh, A., Steffan-Dewenter, I., Kleijn, D., Tscharntke, T. (submitted). Diversity of flower-visiting bees in cereal fields: effects of farming system, landscape composition and regional context.

Holzschuh, A., Steffan-Dewenter, I., Tscharntke, T. (submitted). Landscape-scale effects of crop-noncrop resource fluxes: organic farming enhances bee diversity in fallow strips.

Holzschuh, A., Steffan-Dewenter, I., Tscharntke, T. (submitted). Landscape context, organic farming and fallow strips influence nest colonization of bees and wasps.

Holzschuh, A., Steffan-Dewenter, I., Tscharntke, T. (submitted). Grassy corridors in cropland landscapes enhance nest site colonization of solitary wasps.

Clough, Y., Holzschuh, A., Kleijn, D., Kruess, A., Steffan-Dewenter, I., Tscharntke, T. (submitted). Bird densities in small-scale agricultural landscapes with mosaics of organically and conventionally farmed fields.

Clough, Y., Holzschuh, A., Gabriel, D., Purtauf, T., Kruess, A., Steffan-Dewenter, I., Tscharntke, T. (submitted). Effects of organic management, dispersal ability and species group on $\alpha$ and $\beta$ diversity in agricultural landscapes.

Kleijn D., Baquero R.A., Clough Y., Diaz M., De Esteban J., Fernandez F., Gabriel D., Herzog F., Holzschuh A., Johl R., Knop E., Kruess A., Marshall E.J.P., SteffanDewenter I., Tscharntke T., Verhulst J., West T.M. \& Yela J.L. (2006) Mixed biodiversity benefits of agri-environment schemes in five European countries. Ecology Letters, 9, 243-254. 
Nowicki P., Richter A., Glinka U., Holzschuh A., Toelke U., Henle K., Woyciechowski M., Settele J. (2005) Less input same output: simplified approach for population size assessment in Lepidoptera. Population Ecology, 47, 203-212.

Holzschuh, A., Steffan-Dewenter, I., Tscharntke, T. (2005) Trap-nesting bee and wasp communities on organic and conventional fields, comparing local and landscape scales. Verhandlungen der Gesellschaft für Ökologie, 35, 166.

Holzschuh, A., Steffan-Dewenter, I., Tscharntke, T. (2004) Bees on organic and conventional fields in different landscapes and regions. Verhandlungen der Gesellschaft für Ökologie, 34, 201.

Holzschuh, A., Mody, K., Linsenmair, K.E. (2000) Formiciden strukturieren Arthropoden-Gemeinschaften: Interaktionen von Ameisen und Herbivoren auf Pseudocedrela kotschyi. 13. Jahrestagung der Gesellschaft für Tropenökologie, 30. 


\section{Curriculum vitae}

\section{Andrea Alexandra Violetta Holzschuh}

geboren am 27.10.1976

in Alzenau i. Ufr.

2002-2006 Promotion am Fachgebiet Agrarökologie der Georg-August-Universität Göttingen unter der Betreuung von Prof. Dr. Teja Tscharntke und PD Dr. Ingolf Steffan-Dewenter

2001-2002 Diplomarbeit zur Anwendbarkeit des Robusten Versuchsplans für die Populationsgrößenschätzung am Beispiel des Esparsetten-Widderchens Zygaena carniolica (Lepidoptera: Zygaenidae) im Landkreis Haßberge unter der Betreuung von Prof. Dr. H.-J. Poethke (Uni Würzburg) und PD Dr. J. Settele (UFZ Halle-Leipzig)

1996-2002 Studium der Biologie an der Julius-Maximilians-Universität Würzburg, Fächer Zoologie, Genetik, Botanik und Pharmazeutische Biologie 